UNIVERSIDADE DE SÃO PAULO

FACULDADE DE FII OSOFIA, IFTRAS E CIÊNCIAS HUMANAS

DEPARTAMENTO DE LETRAS CLÁSICAS E VERNÁCULAS

PROGRAMA DE PÓS-GRADUAÇÃO EM LITERATURA BRASILEIRA

O corpo da noite: Uma leitura de "Buriti", de João Guimarães Rosa.

\title{
(VERSĀO CORRIGIDA)
}

Edinael Sanches Rocha

Tese apresentada ao Programa de PósGraduação $\mathrm{cm}$ Literatura Brasilcira do Departamento de Letras Clássicas e Vernáculas da Faculdade de Filosofia, Letras e Ciências Humanas para a obtenção do título de doutor em Letras.

Orientadora: Prof ${ }^{a}$. Dr ${ }^{\mathrm{a}}$. Yudith Rosenbaum

De acordo,

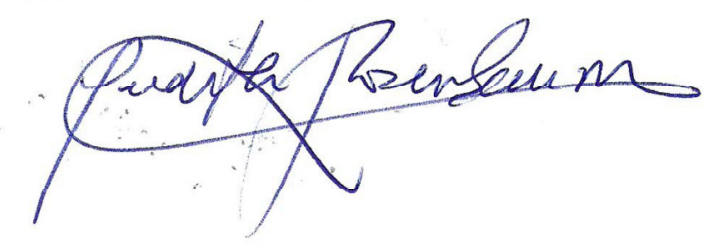

São Paulo 


\section{FOLHA DE APROVAÇÃO}

Edinael Sanches Rocha

O corpo da noite: Uma leitura de Buriti, de João Guimarães Rosa.

Tese apresentada ao Departamento de

Letras Clássicas e Vernáculas da

Faculdade de Filosofia, Letras e Ciências Humanas da Universidade de São Paulo para a obtenção do título de doutor.

Área de concentração: Literatura Brasileira.

Aprovado em:

Banca Examinadora

Prof. Dr.

Instituição:

Assinatura:

Prof. Dr.

Instituição:

Assinatura:

Prof. Dr.

Instituição:

Assinatura:

Prof. Dr.

Instituição:

Assinatura:

Prof. Dr.

Instituição: Assinatura: 
Para as minhas Estrelas, Ana Thereza e Francisco, com amor.

Aos meus pais, Edmundo e Lauraci, com gratidão. 


\section{AGRADECIMENTOS}

À Profa. Dra. Yudith Rosenbaum por sua orientação rigorosa e carinhosa, sempre permeada de espaço para a liberdade de criação e diálogo.

Às professoras que participaram do exame de qualificação: Prof ${ }^{\mathrm{a}}$. Dr ${ }^{\mathrm{a}}$. Cleusa Passos e Prof ${ }^{a}$. Dr ${ }^{\mathrm{a}}$. Adélia Bezerra de Meneses pelas valiosas críticas, sugestões, indicações bibliográficas, além dos elogios, que muito contribuíram para a conclusão deste trabalho.

Aos membros da banca de defesa: Cleusa Passos, Adélia Bezerra de Meneses, Betty Mindlin e José Miguel Wisnik pelas valiosas arguições, críticas sugestões e elogios.

À minha mulher, Ana Thereza, pelo grande Amor, pela parceria, paciência e incentivo contínuos.

Ao meu filho, Francisco, por sua doce impaciência e constante alegria.

À Prof ${ }^{\mathrm{a}}$. Dr ${ }^{\mathrm{a}}$ Eliane Robert Moraes pelo convite para participar do Seminário Internacional "Poética das Margens", fato que muito contribuiu para o desenvolvimento de algumas ideias importantes presentes neste trabalho.

Aos meus pais, Edmundo e Lauraci, pelo investimento que me possibilitou ser quem eu sou.

Às minhas colegas da Vara da Infância e Juventude do Fórum de Santo Amaro e de Pinheiros, psicólogas e assistentes sociais, por "segurarem as pontas" enquanto precisava me ausentar para vir à USP cumprir os créditos do doutorado.

Aos amigos que, direta ou indiretamente, contribuíram com trocas de figurinhas, leituras, indicações de leitura e muito apoio: Célia Regina Cardoso (pela leitura e revisão mais que eficiente), Rosa Maria Rodrigues dos Santos, Uri Lam, Jean Carlo Faustino. 


\section{RESUMO}

ROCHA, E. S. O corpo da noite: Uma leitura de Buriti, de João Guimarães Rosa. 2016. 127 f. Tese (Doutorado) - Faculdade de Filosofia, Letras e Ciências Humanas, Universidade de São Paulo, São Paulo, 2016.

O objetivo desta tese de doutorado é propor uma leitura interpretativa de "Buriti", de João Guimarães Rosa. Para compreender o erotismo característico da narrativa, tema desta tese, investiga-se a forma como se constitui o espaço narrativo e seu caráter mítico. Num espaço ex-cêntrico, pleno de possibilidades, há ocasião para o questionamento de práticas e preceitos relacionados à moral sexual da sociedade patriarcal brasileira, em trama híbrida entre os planos do mito e da história. $\mathrm{O}$ estudo dos elementos da natureza e sua valoração erótica, considerando sua relação com as personagens e o desenvolvimento da trama, é o ponto de partida. Desde os elementos mais evidentes, como o Buriti Grande ou o Brejo do Umbigo, até aqueles que parecem meros acessórios, revela-se o processo de erotização da natureza empreendido pelo autor, sobretudo na flora e solo sertanejos, constituindo o "corpo da noite". A partir de indicações do texto, a noite, a lua e o mutum, bem como sua relação com a mitologia dos índios brasileiros, são também foco das análises. Considerando a filiação "por varonia" dos filhos do sertão, a noção de totemismo, tomada da antropologia estrutural, serve de mediadora para o estudo do encontro entre os representantes de dois clãs familiares próprios da ficção rosiana, Maria da Glória, filha do buriti e Miguel, do mutum, considerando que estes personagens trazem em seu nome, a marca do sertão. Por fim, as insistentes referências ao corpo das personagens e seus "territórios eróticos", homólogo ao corpo da natureza, são analisados em sua relevância para a marcação de pontos críticos da narrativa. A abordagem privilegia as marcas estilísticas e aproveita, em momentos pontuais, algumas contribuições da psicanálise.

Palavras chave: Buriti, Guimarães Rosa, Mito, Corpo, Literatura brasileira 
ABSTRACT

ROCHA, E. S. The body of the night: A reading of Buriti, by João Guimarães Rosa. 2016. Thesis (Doctoral) - Faculdade de Filosofia, Letras e Ciências Humanas, Universidade de São Paulo, São Paulo, 2016.

The purpose of this doctoral thesis is to propose an interpretive reading of "Buriti" by João Guimarães Rosa. In order to understand the typical narrative eroticism, theme of this thesis, it investigates the way the narrative space is constituted as well as its mythical character. An ex-centric space, full of possibilities, there is occasion for questioning practices and principles related to the sexual morality of the Brazilian patriarchal society, in hybrid plot between the planes of mith and history. The study of the elements of nature and its erotic valuation, considering its relationship with the characters and the plot development is the starting point. Since the most obvious elements, such as the Buriti Grande (Great Buriti) or the Brejo do Umbigo (Navel Heath), even those who seem mere accessories, reveal the sexualization process of nature undertaken by the author, especially in flora and backwoods soil, constituting the "body of the night" . From text directions, the night, the moon and the curassow, as well as its relationship to the Brazilian Indians mythology are also the focus of the analysis. Considering the filiation "by male line"of the children of the hinterland, the notion of totemism, taken from the structural anthropology, mediates the study of the meeting between the representatives of two family clans typical of Rosa's fiction, Maria da Gloria, Buriti's daughter and Miguel, the curassow, considering that these characters bring in their name, the brand of the hinterland. Finally, the repeated references to the body of characters and their "erotic territories," homologous to the body of nature, are analyzed in their relevance for the marking of critical points of the narrative. The approach favours the stylistic marks and employs, in specific moments, some psychoanalysis contributions.

Key words: Buriti, Guimarães Rosa, Mith, Body, Brazilian Literature 


\section{SUMÁRIO}

Introdução___ 9

1 - O jardim das delícias terrenas: erotismo natural, erotismo humano___ 19

1.1- O jardim das delícias terrenas___ 22

1.2 - Água___ 24

1.3 - Água e terra: brejo, árvores e flores__ 25

1.4 - Brejo masculino: árvores___ 33

1.5Brejofeminino: flores___ 37

1.6 - O brejo do encontro: terrível delícia___ 42

1.7 - Para concluir __ 47

$2-\mathrm{O}$ corpo da noite: polifonia indígena___ 50

2.1 - A noite: presente da Cobra Grande para os amantes___ 52

2.1.1 - Paraíso perdido___ 54

2.2 - O noturno rumor

2.2.1 - Intermezzo: Para além dos confins do ouvir 61

2.3- $\mathrm{O}$ rumor do mutum 65

2.4 - Mutum, solista 72

2.4.1 - Mutum, Crax, Caz: o nome do pai 74

2.5 - O mutum e a lua 78

2.6 - Da lua ao lampião: um desfecho 83 
3 - Os clãs e seus totens 88

3.1 - Os totens: casamento dos opostos 91

3.2 - Os filhos deste solo 95

3.2.1- A palmeira 98

3.2.2 O pássaro 100

3.3 - Totem: antepassado mítico e atualidade paterna 105

3.3.1- Liodoro:árvore 107

3.3.2 - Bernardo: a fúria 113

3.4 - O desejo por totem: Lalinha 116

4 - O corpo da noite: da natureza erotizada ao corpo erógeno 125

4.1 -Monjolo, marcador do desejo 133

4.2 - Os limiares do corpo 136

4.3 - Boca da noite 139

4.4 - Encruzilhada dos sentidos 143

4.5 - Corpo com corpo 148

4.6 - Post Scriptum - "Mulheres têm a ideia sem sossego..." / "Mulher tira ideia é do corpo..." 153

Considerações Finais 158

Referências 168 
Introdução 


\section{INTRODUÇÃO}

"O amor exigia mulheres e homens ávidos tãomente da essência do presente, donos de uma perfeição espessa, o espírito que compreendesse o corpo.” (B, 192) "Lá dentro, se enrolava o corpo da noite mais defendida e espessa." (B, 124) ${ }^{1}$

O objetivo desta tese é analisar e interpretar a novela "Buriti", de João Guimarães Rosa, visando uma melhor compreensão dos fenômenos eróticos ali representados. O ponto de partida é a ideia de que a atenção à corporeidade dos entes da natureza se faz indispensável para a melhor apreciação crítica desta novela. Se, de acordo com a reflexão da personagem Lalinha, em epígrafe, parece evidente a necessidade de compreensão do corpo pelo espírito na questão do amor - dada a uma dicotomia passível de ser localizada na história do pensamento humano, pelo menos desde Platão - ver na noite um corpo com suas demandas próprias (um feito poético) não é menos necessário para a interpretação da obra em questão.

Defende-se aqui o princípio de que o erotismo presente em "Buriti" é propiciado pelo sertão - talvez o personagem mais importante de toda a obra de Guimarães Rosa. Personagem porque participa ativamente da narrativa, de maneira difusa, mas decisiva, sem nada falar, mas fazendo-se ouvir. Perseguem-se aqui os índices da natureza, plena de significação erótica, que influenciam, ou, antes, propiciam a experiência erótica dos habitantes do Buriti Bom.

Este jardim poético, plantado pelo demiurgo Rosa na tradição literária brasileira, parece até agora pouco apreciado pela crítica se comparado, por exemplo, a Grande sertão: veredas. A proposta de leitura aqui apresentada objetiva levar em conta a singularidade da obra, apresentando como uma de suas características distintivas a dispersão pelo texto destes signos eróticos constituintes da natureza de "Buriti", desde o mais evidente - o Buriti Grande - até os mais sutis e aparentemente acessórios.

Pretende-se provar através da interpretação da obra o estabelecimento de uma dinâmica entre a flora e os demais elementos relativos à terra e ao ambiente no qual se inserem as personagens, de forma que aos habitantes das terras de iô Liodoro cabem o fruir deste "erotismo natural". Ao longo dos capítulos pretende-se construir um texto interpretativo que abarque o movimento que vai da natureza constituída de forma

\footnotetext{
${ }^{1}$ Todas as referências a "Buriti", de Guimarães Rosa, referem-se ao volume Noites do sertão: $4^{\mathrm{a}}$ ed. Rio de Janeiro: José Olympio, 1969 e serão apresentadas aqui entre parênteses, indicadas por um "B" seguido do número da página.
} 
erótica pelo autor até as personagens, para que o entendimento do erotismo manifesto ou latente - dos habitantes do Buriti Bom seja elaborado, em certa medida, como resposta à sua inserção neste ambiente "não semelhante e retirado de rota". $(B, 93)$

Ora, falar de uma natureza que é personagem da história, com papel decisivo na trama narrativa, é falar da força do mito presente na constituição de "Buriti". Ao tratar da presença do mito no âmbito da literatura brasileira, o crítico Benedito Nunes (2009, p. 291) chama a atenção para o que chama de "surto" do mito no romance, listando diversos momentos nos quais se percebe a aproximação da prosa nacional desta categoria.

Nunes retoma José de Alencar, expressando sua "preocupação de identidade nacional" como em $O$ guarani, além da mitificação do homem regional, com $O$ sertanejo e $\mathrm{O}$ gaúcho. Ressalta também a importância desta categoria para o Modernismo, sobretudo levando em conta a feitura do Macunaíma de Mário de Andrade.

Na síntese do crítico paraense, o mito:

seria um conto ao qual não se pode atribuir um autor determinado ou que teria inúmeros autores sem identidade pessoal; mesmo quando registrado num determinado momento, ele vem de muito longe, não procede de alguém e parece provir, conforme já se admitiu, de um difuso colegiado ou da própria coletividade. [...] Daí ser o mito considerado ao mesmo tempo a história das origens e a história original ou a mãe dos contos, situada extraliterariamente e de maneira tardia como texto escrito numa tradição religiosa determinada. (NUNES, 2009, p. 292)

Ao abordar o mito na obra de Guimarães Rosa, o mesmo Benedito Nunes aponta para o mítico pacto demoníaco encenado em Grande sertão: veredas, que remonta ao Fausto de Goethe, que, por sua vez, remete à história bíblica de Jó. Ao iniciar a investigação sobre a força da natureza na constituição do erotismo em "Buriti”, logo se depara com as indicações mais do que sugestivas a respeito do Jardim do Éden, presente no livro do Gênesis.

Já Adorno e Horkheimer (1985, p. 20) afirmam: "o mito queria relatar, denominar, dizer a origem, mas também expor, fixar, explicar”. Tal afirmação vem no contexto da contraposição desta categoria - mito - com o esclarecimento. Argumentam que, embora o esclarecimento vise a desmitologização do mundo com vias à sua dominação por uma pretensa racionalidade que tudo calcula e explica, o mito, ele 
mesmo, pode ser considerado como uma forma de esclarecimento face à realidade concreta da vida.

Não por acaso diversas são as menções ao Éden bíblico que "brotam” do texto de Rosa, além de referências mais ou menos explícitas a outras tradições - como a dos índios brasileiros - e suas narrativas que têm por objetivo "dizer a origem" das coisas. É possível, portanto, por força da análise que se pretende aqui, delimitar, ou caracterizar, o espaço narrativo do Buriti Bom como um jardim, ainda pleno do frescor mítico da aurora dos tempos, no qual a terra e seus frutos exalam uma sensualidade típica e, plantados ali, não exatamente o casal mítico, mas as personagens da trama: Liodoro e sua família, além dos demais. Habitar as terras deste locus específico do sertão rosiano é estar submetido às condições extraordinárias do lugar, que terão as suas consequências deslindadas ao longo da trama.

Alfredo Bosi (2006, p. 433), ao tratar da força do mito no texto de Guimarães Rosa, escreve: "toda a sua obra nos põe em face do mito como forma de pensar e de dizer atemporal". No caso de "Buriti" se verá que estas condições míticas de composição e caracterização do espaço narrativo e seus múltiplos elementos entrarão em atrito com a matéria histórica do grupo social ali representado.

Isto porque não se trata de mera fabulação em torno do mito. Haverá ali ocasião para a manifestação do mítico, justamente porque se abre a ocasião para o acontecer da lenda ("Ali nada podia acontecer, a não ser a lenda." (B, 132)), mas a escrita rosiana não deixa de lado a matéria histórica na elaboração da trama.

A organização familiar centrada na figura do patriarca, o modo de produção do Brasil rural da primeira metade do século XX, a ética amorosa pautada pela dupla moral, desigual para homens e mulheres, com o fundo típico da noção de pecado e valorização da virgindade (feminina), são alguns dos elementos históricos facilmente identificáveis nesta obra.

Em diversos momentos, portanto, será possível entender o mito como narrativa das origens, o que contribui decisivamente para a caracterização do lugar "retirado de rota", lendário, povoando a natureza, sendo sua própria carne. As personagens movemse sob este fundo mítico, sob a influência destas emanações ancestrais de um erotismo telúrico.

Mas, sobretudo na segunda parte da novela, sob a perspectiva de Lalinha, haverá ocasião para a problematização quanto a algumas práticas e/ou costumes da vida erótica 
na sociedade patriarcal brasileira, sendo legítimo entender o termo "mito" no sentido empregado por Roland Barthes, como naturalização da história, como processo que elide a construção social do que está aí, dando ao social a aparência de algo que sempre existiu, legitimando-o.

O esforço de Lalinha e Maria da Glória por buscarem um entendimento entre corpo e espírito fará com que elas se descolem deste fundo mítico, ou desta história mitificada, desta malha de pressupostos fixos sobre os lugares e modos de relação estabelecidos e estanques para homens e mulheres.

Para Barthes (1980, p. 163), o mito "é constituído pela eliminação da qualidade histórica das coisas: nele, as coisas perdem a lembrança da sua produção.” Entende este autor o mito como uma "fala despolitizada", entendendo por política, o "conjunto das relações humanas na sua estrutura real, social, no seu poder de construção do mundo." (Idem, p. 163)

Não que Lalinha e Maria da Glória façam um grande movimento de questionar os ditames de sua condição, mas suas conversas, reflexões e ações ao longo da trama levam-nas "naturalmente" a se opor a alguns destes ditames, como o privilégio masculino na liberalidade das práticas sexuais - atualizado no comportamento de Liodoro - e a condição de recato e submissão comumente atribuídas à mulher. Neste processo, a narrativa de Do-Nhã e sua vida "estúrdia", além da tentativa de entendimento sobre o casamento fracassado de Lalinha e Irvino são episódios fundamentais para o entendimento dos desdobramentos relativamente inusitados de "Buriti".

Portanto, articulam-se no presente estudo dois entendimentos distintos para o mesmo significante. $\mathrm{O}$ mito das origens, que contribui para a caracterização do lugar e sua natureza fantástica, onde virtualmente tudo pode se dar. Isto se afina com a propiciação da "lenda", conforme anotação do próprio narrador. Ao fazer acontecer aquilo que se espera de um lugar "retirado de rota", há ocasião para certo distanciamento daquilo que é comum, ordinário. Já o mito entendido no sentido barthesiano, ou a história mitificada - com a licença do uso deste termo - é isto que as personagens podem por em xeque devido ao relativo esgarçamento de alguns recalques, graças àquilo que é propiciado por este "lugar de agrado" que é o Buriti Bom.

Em diversos momentos de "Buriti", será possível perceber este movimento de atrito entre certos "mitos" ou práticas da sociedade brasileira - naturalizados de tão 
antigos - com uma perspectiva distinta. Apresentar-se-á, sobretudo na segunda parte da novela, este recurso de inserir esta dupla torção relativa ao foco narrativo: Lalinha, uma mulher (primeira torção) da cidade (segunda) de passagem pelo sertão, que praticamente domina a perspectiva, entremeada com a narração em terceira pessoa.

Diga-se, aliás, sobre o foco narrativo de "Buriti" que este é oscilante, ao modo do que Adorno (2003, p. 61) reflete em seu texto "Posição do narrador no romance contemporâneo". O crítico aponta para os movimentos do narrador, análogos aos da câmera cinematográfica, ora distanciando, ora aproximando, levando a caminhos inesperados conforme a intenção do autor. Na novela de Rosa é fácil notar esta movimentação, de um narrador em terceira pessoa para o interior da subjetividade de Miguel ou Lalinha, até para o bobo Zequiel e sua escuta da noite, além de momentos nos quais narrador e natureza parecem fundir-se, havendo mais do que mera descrição, mas o registro da linguagem do sertão, do "corpo da noite".

Já que se falou em perspectiva, foco narrativo e mito, vale evocar aqui Anatol Rosenfeld e seu texto "Reflexões sobre o romance moderno", que serve também como baliza para a presente pesquisa. Este crítico anota a relevância do mito como ponto de chegada, intencional ou não, das transformações pelas quais passaram as artes no início do século XX e, em particular, o romance. O pensamento de Rosenfeld mostra-se em acordo com a observação de Adorno sobre a supressão da distância do narrador das obras realistas, além de frisar o esfacelamento do sujeito, e o questionamento acerca da clara delimitação espaço-temporal.

De posse destas reflexões, é relevante observar em "Buriti" o confronto entre o mito e a história, justamente nos termos em que expõe Rosenfeld (1996, p. 89): “é intemporal o 'tempo mítico' que, longe de ser linear e progressivo (como é o tempo judaico cristão), é circular, voltando sobre si mesmo." A questão temporal, sobretudo quando percebida pela personagem Lalinha, será relevante como forma de vislumbrar as idiossincrasias do lugar e seus habitantes, franco contraste entre sua condição moderna e ex-cêntrica, num ambiente que parece não se abrir ao fluir do tempo histórico.

A título de sistematização do que será desenvolvido nesta tese, tem-se a seguinte divisão:

No capítulo 1 o mito judaico de origem da humanidade ajuda a entender o tipo de espaço narrativo constituído em "Buriti", assim como a condição de existência dos seres que habitam este espaço. Será estudado aqui o processo de erotização da natureza, 
através do qual o sertão se torna, no decorrer da trama, fonte primeira do erotismo telúrico que, em diversos trechos, pode-se constatar.

Após sucessivas leituras tanto da narrativa quanto de sua fortuna crítica, constatou-se que ainda há espaço, ao lado das pesquisas já desenvolvidas sobre o tema, para um estudo mais sistemático dos elementos da natureza e sua valoração erótica, a saber: a flora, a água, o "Brejo do Umbigo", assim como a noite, a lua, etc., para que se tivesse uma nova perspectiva de interpretação para esta obra. Após uma investigação mais detalhada sobre a relevância simbólica destes elementos na composição do texto, seria possível estabelecer uma articulação entre o "erotismo da natureza" e o erotismo tal qual experimentado pelas personagens.

Além das referências ao Jardim do Éden no texto de Rosa, leva-se em conta ainda o comentário de Gunter Lorenz publicado em 1966 por ocasião da publicação da obra de Rosa na Alemanha. O crítico alemão escreve, referindo-se a Corpo de baile e ao espaço narrativo: “o sertão [...] do Brasil, um mundo no dia da Criação, povoado por homens que ainda não perceberam as consequências do pecado original, que ainda não derrubaram as pontes para o paraíso.” (LORENZ apud ROSA, 2003, p. 377)

O foco de análise no primeiro capítulo, considerando o Buriti Bom como espaço que mantém certa identidade com a criação mítica, recai sobre a dispersão erótica nas flores, árvores, na água que envolve a terra até o central Brejão do Umbigo e sua estratégica função figurativa do infinito ciclo de fecundidade, reprodução e morte. É neste ambiente feérico que se acha ocasião para a manifestação do erotismo de Liodoro, Maria da Glória e os outros membros do clã Faleiros. Portanto, para um melhor entendimento disto que se passa com as personagens é que se dá "um passo atrás", principiando a análise e interpretação de "Buriti" a partir da ligação entre o homem e a terra, levando em consideração os enunciados críticos do clássico ensaio de Antonio Candido "O homem dos avessos".

O crítico salienta, ao analisar o espaço de Grande sertão: veredas, "que a flora e a topografia obedecem frequentemente a necessidades de composição; que o deserto é sobretudo projeção da alma, e as galas vegetais simbolizam traços afetivos." (CANDIDO, 1971, p.124) Em "Buriti", espaço "retirado de rota", nada se parece com o liso do Sussuarão e sua secura, a simbolizar, além das asperezas da alma, a crueldade da violência que permeia as relações jagunças. Antes, se observará no Buriti Bom a riqueza das águas e exuberância de flora, além do decisivo poder de Buriti Grande, que "alto 
maquineja" e dá o tom do baile erótico, ao som da melodia noturna deste pedaço do sertão rosiano.

Prosseguindo a trilha da natureza, do mundo vegetal chega-se, no capítulo 2, pela mitologia indígena, à noite propriamente dita, lembrando, embora isto possa parecer redundante, que "Buriti" integra o volume Noites do sertão. Com pouco esforço, se estabelece a relação entre o erotismo vegetal e a fauna e flora noturnas, já que a lua, Yaci para os índios, é a "mãe do mato". Rosa deixa poucas, mas significativas pistas, sobre a importância da tradição indígena para a composição da obra. Leia-se, com o peso devido, a nomeação do Buriti Grande de "Palmeira do Curupira" e se terá, diante de si, a abertura para o caminho que leva da palmeira que dá título à novela, à evocação de uma riquíssima tradição mítica que fundamenta a existência mesma de entes decisivos para compreender o fenômeno erótico na novela, tais como a noite, a lua e o mutum. O mito da Cobra grande e o nascimento da noite é o ponto de partida de uma articulação entre o texto rosiano e alguns elementos da mitologia indígena que indicam pertinentes relações de sentido pouco estudadas até agora nesta narrativa.

No capítulo 3, a partir dos achados no capítulo precedente e de uma sugestão do crítico Luiz Roncari, investigou-se a possibilidade de se pensar o poder totêmico do Buriti Grande na regência amorosa dos habitantes locais. Falar em totem é, evocando a antropologia estrutural de Claude Lévi-Strauss, falar em antepassado mítico. O buriti, palmeira que une céus e terra, símbolo solar, índice da exuberância da flora local, constitui-se como inegável antepassado do clã de Liodoro Maurício Faleiros, sendo Maurítia Vinífera o nome científico do buriti.

Neste capítulo, levando às últimas consequências a afirmação de Roncari, buscase compreender o espaço de "Buriti" como aquele no qual se encena o encontro não apenas de Maria da Glória e Miguel, mas de grupos familiares, clãs internos à obra de Guimarães Rosa, regidos por totens próprios: o buriti e o mutum (Crax Alector), marca do sobrenome "Caz" da família de Miguel/Miguilim, segundo "Campo geral". O sertão e sua ancestral carga simbólica se faz presente, como se vê, em toda parte: do mais evidente elemento externo, o cerrado que existe deveras e é transmutado poeticamente para dentro do livro, ao nome dos personagens que une a tradição mítica à possibilidade de manifestação de suas subjetividades de papel.

Se o "sertão é dentro da gente", como afirma Riobaldo, a externalização do impulso erótico implica neste "corpo a corpo" das personagens entre si, humanas ou 
não. Assim, falar de erotismo é falar de corpo. Seja o "corpo da noite", estudado nos capítulos 1 e 2, seja o corpo mesmo das personagens, tratar deste lugar, nascente do desejo, é tarefa imprescindível. Sem pretender esgotar a importância do corpo erógeno em "Buriti", o capítulo 4, pretende abordar alguns pontos significativos concernentes a esta categoria, tendo como referência a psicanálise de Freud. Mais uma vez aqui evocase a categoria do mito, n'O banquete de Platão, referência para a escrita de Rosa e ponto de partida da reflexão neste momento.

A conclusão, além de sintetizar brevemente os capítulos aqui apresentados, buscará articular a relevância da natureza literariamente criada pelo autor, plena do vigor mítico da Criação, espaço de exceção e experimentação, sobretudo para as personagens femininas, e a possibilidade de por em perspectiva algumas práticas miticamente naturalizadas da sociedade brasileira.

Na defesa desta hipótese, em termos metodológicos, a análise estilística da obra encontra papel decisivo. Alfredo Bosi (1988, p. 275) lembra a ligação entre o sentido do verbo ler e sua origem comum com o verbo colher. Interpretar, por sua vez, é eleger, escolher, "na messe de possibilidades semânticas, apenas aquelas que se movem no encalço da questão crucial: o que o texto quer dizer?".

Seguindo os passos do crítico brasileiro, que se inscreve na tradição da hermenêutica de Leo Spitzer e Schleiermacher, entre outros, trata-se de percorrer o texto com a atenção voltada para a relação dos pormenores semânticos, lexicais, e o plano geral da obra. Desta forma, a investigação das imagens textuais e das imbricadas construções verbais do escritor mineiro se dará no sentido de flagrar a construção desta rede de significados que compõe o erotismo natural nas páginas de "Buriti", sempre levando em conta as oscilações de perspectiva narrativa ensejadas pelo autor.

Caberá aqui, no âmbito desta pesquisa, estudar cuidadosamente a linguagem utilizada por Rosa na composição da trama e das imagens que integram o texto ou, como no dizer de Eric Auerbach (1972, p. 41), "considerar somente o texto propriamente dito e observá-lo com uma atenção intensa, sustentada, de modo que nenhum dos movimentos da língua e do fundo nos escape".

No caso específico de Guimarães Rosa, conforme já apontado pelo crítico Alfredo Bosi (1988, p. 22), observar-se-á uma vertente particular de seu estilo de "prosador virtuosista que se dá de corpo e alma às sensações do mundo e às impressões das suas criaturas". No vagar pelo texto noturno por excelência de "Buriti", a leitura 
deverá deter-se sobre o "dispersar-se na floresta das imagens e dos sons" do sertão literário no qual o autor habilmente semeou os signos de um erotismo ancestral que se choca com a atemporalidade e a atualidade do desejo humano.

Observe-se ainda que, sobretudo nos capítulos 2 e 3, alguns trechos de "Campo geral" serão também cotejados, por força da interpretação aqui proposta, tendo em vista a ligação evidente entre o Miguel de "Buriti" e o Miguilim da novela que abre Corpo de baile.

Comecemos, então, pela erotização da natureza, marca do texto rosiano e matriz analítica da presente tese. 
Capítulo 1 - O jardim das delícias terrenas: erotismo natural, erotismo humano. 


\section{CAPÍTULO 1}

\section{O jardim das delícias terrenas: erotismo natural, erotismo humano.}

\section{Introdução}

"Buriti" é uma extensa novela que integra Corpo de baile e encerra este ciclo de narrativas ao mesmo tempo em que indica seu reinício, levando em conta o índice original da obra ${ }^{2}$. Uma leitura crítica da novela não se faz sem um conhecimento apurado da palmeira que intitula a narrativa e do meio no qual ela se encontra, tanto no plano objetivo como nos níveis simbólico e literário.

Neste capítulo, visando a interpretação de pontos ainda pouco estudados pela crítica rosiana, será investigada a relevância simbólica de alguns elementos da natureza, como a água, o brejo e a vegetação que compõem a paisagem literária de "Buriti".

A intenção é mostrar a articulação entre o erotismo que permeia a narrativa, nas ações, diálogos e monólogos internos das personagens, e a composição de uma natureza, em termos literários, impregnada de signos referentes à volúpia e à fertilidade, que, de certa forma, influenciam e/ou propiciam o erotismo das personagens.

Defende-se aqui a ideia de que a natureza criada por Rosa exerce papel decisivo para a interpretação desta narrativa, ficando parte significativa do entendimento do valor de "Buriti" dependente da apreciação desta relação entre o erotismo, fenômeno humano por excelência, e a saturação da natureza por estes mesmos elementos.

Nos diversos momentos em que, tanto nas fantasias quanto nas ações de certas personagens, observa-se certo esgarçamento das barreiras culturalmente constituídas ${ }^{3}$ em relação à sexualidade, a tese é de que isto se dá, em parte, pela facilitação que o próprio ambiente do Buriti Bom proporciona.

Retomando o argumento de Freud exposto em "O mal-estar na civilização" sobre a necessária "renúncia à pulsão" para a constituição da civilização ou mesmo as restrições para a consecução do gozo sexual, pelas relações monogâmicas e legitimadas socialmente, é fácil notar o quanto em "Buriti" estas elaborações são relativizadas, principalmente em relação às personagens io Liodoro, Maria da Glória e Leandra. A condição do Buriti Bom, descrito pelo narrador como lugar "retirado de rota", afeito ao

\footnotetext{
${ }^{2} \mathrm{O}$ índice de Corpo de baile, antes de sua divisão em três volumes, indicava a ordem de apresentação das novelas e, ao final, um novo índice, com a ordem invertida, indicando, ao final, um recomeço.

${ }^{3}$ As elaborações freudianas acerca das barreiras próprias à sexualidade humana, sobretudo nos capítulos 3 e 4 de "O mal-estar na civilização" (FREUD, 1930/2010), estão aqui subentendidas ao longo do texto.
} 
acontecimento da "lenda", contribui para certo clima, dominante na narrativa, de desafio às renúncias e restrições postuladas por Freud.

Isto posto, esclareça-se que frente a este erotismo "retirado de rota", transgressivo, portanto, mostra-se pertinente a definição de erotismo empregada aqui, conforme a elaboração de Georges Bataille. Este autor pensa o erotismo como algo distinto da atividade sexual voltada para a reprodução. Escreve Bataille (2013, p. 35): “[...] apenas os homens fizeram de sua atividade sexual uma atividade erótica, ou seja, uma busca psicológica independente do fim natural dado na reprodução e no cuidado com os filhos."

Dentre os elementos característicos do erotismo, o pensador francês frisa (Op. Cit.p. 42): “o que está em jogo no erotismo é sempre uma dissolução das formas constituídas. Repito-o: dessas formas de vida social, regular, que fundam a ordem descontínua das individualidades definidas que somos". E, mais adiante, Bataille (Idem, p. 118) escreve: “o erotismo em seu conjunto é infração à regra dos interditos: é uma atividade humana."

Tais definições mostram-se bastante apropriadas para pensar o desenrolar da ação em "Buriti", uma vez que no texto de Rosa a atividade erótica distingue-se claramente destas "formas de vida social", sobretudo o mundo do trabalho, sendo a ocasião para a entrada em cena do extra-ordinário, momento de busca da realização dos desejos por meio da infração ou transgressão de certos interditos, além do questionamento em relação aos limites tanto do sujeito quanto das normas sociais que regem estas "formas constituídas". 4

Articulada a esta perspectiva, a noção de sexualidade afeita à psicanálise, peça fundamental para a constituição do sujeito, está subentendida ao longo da discussão. Admite-se aqui que tanto nas fantasias como nas ações das personagens a noção de erotismo defendida por Bataille e a de sexualidade freudiana podem se encontrar salvaguardando suas distâncias - sendo, por vezes, pensadas de forma articulada. Esta aproximação soa possível quando se considera, mais uma vez, o pensamento de Bataille (2013, p. 53, grifo do autor) que, em muitos pontos, parece vibrar no mesmo diapasão

\footnotetext{
${ }^{4}$ A crítica rosiana, mais especificamente de "Buriti", já mostrou a pertinência de uma leitura interpretativa desta obra a partir da perspectiva do pensamento de Georges Bataille, conforme o estudo recente de Adélia Bezerra de Meneses, publicado em 2010, "Erotismo e transgressão: o pathos amoroso em "Buriti", p. 119 e seguintes.
} 
que o do pai da psicanálise. "O erotismo do homem difere da sexualidade animal justamente por colocar em questão a vida interior. O erotismo é, na consciência do homem, o que nele coloca o ser em questão". A frase é de Bataille, mas, mesmo consideradas as diferenças entre os dois pensadores, talvez fosse possível pensar numa aproximação pontual entre o erotismo bataillano e a sexualidade tal como entendida pela psicanálise freudiana.

No caso do termo "erotismo natural" empregado no título deste capítulo, esclareça-se desde já que se trata de uma metáfora para tentar dar conta do feito literário de Rosa nesta narrativa. Graças ao uso singular da linguagem, manifesto numa prosa plena de efeitos sinestésicos e figuras de linguagem que reforçam a impregnação de fenômenos humanos na natureza, os fenômenos naturais ganham, neste texto, uma valoração simbólica, literariamente erótica. Tal paisagem exerce sobre as personagens uma quase irresistível influência, segundo se defende aqui, sobre a prática erótica essencialmente humana - dos habitantes do Buriti Bom.

Esclareça-se que o uso do significante erotismo em relação ao trabalho do narrador não coincide com o sentido que Bataille dá a este termo. É certo que a natureza erotizada, por obra do uso singular da palavra poética, é radicalmente distinto do erotismo transgressor elaborado pelo pensador francês. Quando se fala aqui em erotismo natural tem-se em mente o resultado deste trabalho da instância narrativa em "Buriti". A transgressão, pode-se cogitar, seria do autor, via narrador, na medida em que atribui ao sertão qualidades inerentemente humanas, ato criativo por excelência.

\section{1 - O jardim das delícias terrenas}

“o sertão [...] do Brasil, um mundo no dia da Criação, povoado por homens que ainda não perceberam as conseqüências do pecado original, que ainda não derrubaram as pontes para o paraíso." (LORENZ apud ROSA, 2003, p. 377)

As referências ao Jardim do Éden em "Buriti” não são poucas nem ocasionais.

Dona-Dona precisava da maior bondade do próximo, não era imaginável entre as belas grandes árvores, num jardim da banda do oriente, num lugar de agrado. $(\mathrm{B}, 105)$

[...] o sonho era a princípio um jardim de grandes árvores de bela vista, da banda do nascente, um lugar de agrado. Mas o sonho tinha de ser tomado apenas em goles curtos, entre hostilidades. $(\mathrm{B}, 99)$

Eu queria que Glória me chamasse, me ensinasse lugares que fossem dela só - nós dois sob sombra de uma antiga árvore, no centro de um bosque, rodeados de uma outra luz. $(\mathrm{B}, 89)$

Ali, o jardim, de Deus, o laranjal, a noite azulante. (B, 244) 
Haroldo de Campos (2004, p. 21), ao discutir a origem do termo éden, conclui que se trata de um "vocábulo plurissignificante", sendo possível associar a palavra tanto à acepção de 'selva' quanto à 'delícia', 'prazer' ou mesmo 'volúpia'.

Por seu turno, a observação do crítico alemão Gunter Lorenz, citada acima, como epígrafe, trata de situar o ambiente no qual se dá a ação tanto do Corpo de baile quanto de Grande sertão: veredas. Escrita em 1966, por ocasião da publicação da obra de Rosa na Alemanha, este trecho serve como uma entrada possível à interpretação de "Buriti".

"Buriti” traz, indiscutivelmente, um jardim, que se não é o Éden bíblico, guarda algumas semelhanças com aquele ambiente e remete a situações que, como apontou Lorenz, indicam uma forma peculiar de lidar com os interditos culturais, sobretudo em relação à sexualidade.

A evocação da categoria do mito se mostrará, neste capítulo e nos demais, plena de consequências. Isto porque, a menção duas vezes sinalizada deste "lugar de agrado", afastado, edênico, fará, necessariamente, contraposição ao tempo/lugar histórico. Tratase da delimitação de um espaço ficcional-mítico - o Buriti Bom e sua natureza dotada de atributos singulares - dentro do ficcional-gênero, a novela "Buriti".

A hipótese é de que em "Buriti" a tônica é a da suspensão parcial de alguns interditos, do questionamento ou mesmo da franca transgressão das normas sociais que regem a sexualidade. Pode-se observar nesta narrativa certa porosidade, pontos de contato e comunicação entre os padrões socialmente aceitos e outras possibilidades de expressão da sexualidade, sobretudo da perspectiva feminina. Tal funcionamento, defende-se aqui, tem a ver com esta delimitação de um espaço propício a tais acontecimentos, quase como num laboratório onde se realizam experimentos.

Neste processo, a natureza literariamente constituída por Rosa atua de forma decisiva. Com sua exuberância e força irresistíveis, por meio de suas emanações, criamse as condições necessárias para que no enredo se apresentem soluções inusitadas, carregadas de magia e "naturalidade" para os dilemas de algumas personagens relativos à sexualidade.

Esteja o narrador mais próximo à perspectiva deste ou daquele personagem, fica evidente que os elementos da natureza, de valor simbólico fortemente erótico, vão se superpondo, criando uma espécie de saturação. Somados os fenômenos afeitos ao solo, 
à umidade e a vegetação, o resultado é uma quase natural diluição ou dissolução de certas barreiras relativas à sexualidade de algumas personagens.

Este jardim plantado por Rosa na ficção brasileira merece atenção por seu caráter exuberante e seu papel decisivo na construção da narrativa como um todo. Tão importante quanto a fazenda do Buriti Bom em si, edificação de mãos humanas, é sua "mata marginal", "virgem", que iô Liodoro "não consente" que derrubem.

O erotismo das ações das personagens guarda estreita relação com este jardim, voluptuoso da raiz aos galhos mais altos, passando pelos troncos e flores estrategicamente plantadas.

Defende-se aqui a hipótese de que os elementos que compõem esta selva participam da narrativa, emanando uma sensualidade "natural", telúrica, que se reflete sobre as demais personagens. Assim, considerar o caráter erótico desta novela requer uma visada sobre a botânica, a água, terra e outros elementos da natureza, literariamente engendradas nas páginas de "Buriti" que contribuem para a dissolução das barreiras que regulam o erotismo humano enquanto tal.

Esta linha de pesquisa encontra respaldo na leitura de outras obras do próprio Rosa nas quais a natureza atua como personagem. Basta lembrar, por exemplo, do Morro da Garça, ilustre protagonista de "O recado do morro", que "grita" o recado ao Gorgulho, dando início, assim, ao longo de processo de decifração/composição da cantiga que salvará a vida do protagonista, Pedro Orósio.

Do ponto de vista teórico, mencione-se, entre outras referências, as considerações de Antonio Candido (1983, p. 244) sobre Sagarana. O crítico trata da criação do regionalismo de Rosa, distinto daquele "trazido" por alguns autores regionalistas, carregado de dados pitorescos, "da terra", como ele observa. Para Candido, a originalidade de Sagarana, e de Rosa, está na capacidade de criar uma região singular, ficcionalmente incomparável, graças à habilidade do escritor tanto em sintetizar o material observado quanto em animar o texto com seu modo de narrar peculiar. Resulta daí que "a região, deixando de ser para ele, simples localização da história, com funções de pitoresco e anedótico, passa a verdadeira personagem [...], tanta é a persistência e a profundidade com que vêm invocados a sua flora, sua fauna, o seu relevo." (CANDIDO, 1983, p. 246)

As mesmas observações - considerando-se entre outros fatores os 10 anos que separam a publicação de Sagarana e Corpo de baile - podem ser feitas no tocante a 
"Buriti", à fazenda do Buriti Bom, "um lugar não semelhante e retirado de rota" (B, 93) e sua exuberante flora. Se em relação a "A hora e a vez de Augusto Matraga" Candido pode observar "certa entrada de primavera [...] em que a natureza nos comunica sentimento quase inefável, germinal e religioso.", no caso de "Buriti" pode-se identificar, analogamente, o poder da natureza em comunicar sentimentos relativos ao amor e ao erotismo.

Neste sentido, portanto, a presente reflexão se afina com a perspectiva do crítico Luiz Roncari, que, em trabalho recente sobre "Buriti", reconhece a singularidade do ambiente do Buriti Bom, como se ali não houvesse um mero pano de fundo para a ação e frisando o caráter "encantatóri(o) e carregad(o) de todo tipo de referências eróticas". Os elementos naturais que compõem o Buriti Bom, segundo Roncari (2013, p. 128, grifos meus), "nos são apresentados como se fossem os verdadeiros agentes da ação, sendo os homens que ali viviam outras manifestações naturais de sua exuberância, estilisticamente enfatizada pelas enumerações, plasticidade das figuras e sonoridade das palavras." Pretende-se aqui uma investigação mais minuciosa de alguns destes elementos sumariamente referidos no estudo de Roncari.

\section{2 - Água}

"A terra do Buriti Bom tinha muita água", comenta o narrador. "[...] o Buriti Bom era um belo poço parado. Ali nada podia acontecer, a não ser a lenda." (B, 132) Curiosa associação entre a condição da água parada, "poço", e a possibilidade do acontecimento, ou da elaboração ficcional, na categoria da lenda.

Talvez aqui se possa pensar, como Gaston Bachelard, na aproximação da natureza e sua relação com o devaneio ou o sonho, e, por extensão, com a criação poética. Bachelard escreve (1997, p. 8): “reencontro sempre a mesma melancolia diante das águas dormentes, uma melancolia muito especial que tem a cor de um charco numa floresta úmida, uma melancolia sem opressão, sonhadora, lenta, calma."

É o próprio Rosa quem, sugestivamente, associa a criação de "Buriti” ao sonho, numa reflexão sobre seu próprio processo criativo registrado num dos prefácios de Tutaméia: “À 'Buriti' (NOITES DO SERTÃO), por exemplo, quase inteira, "assisti”, em 1948, num sonho duas noites repetido." (ROSA, 1979, p. 157)

Por mais que as indicações do autor possam ter a função de despistar o leitor, não deixa de ser produtivo, em termos críticos, esta aproximação entre o devaneio criador diante de uma água parada, suscitando, justamente, esta "lenda", que é o enredo 
de "Buriti". Um sonho/lenda/romance/poema no qual se unem a origem dos tempos e a atualidade da condição humana em relação ao amor e o erotismo.

O elemento água tem importância indiscutível em "Buriti”, pois está presente tanto no nível das referências mais elementares até às metáforas, às imagens textuais que dizem respeito ao movimento e à estagnação das personagens, aos momentos em que a narrativa estanca ou flui.

Miguel, em seu regresso ao Buriti Bom, no cair da noite, para próximo a um "riachinho bichinho", que o faz relembrar sua passagem anterior pela fazenda, junto com outros sons que compõem o anoitecer. O Miguilim, de "Campo geral", agora adulto, visita a propriedade uma primeira vez, ao acaso, conduzido por Gualberto, proprietário da fazenda vizinha, a Grumixã. A primeira parte de "Buriti" se dá num grande flash-back, quando Miguel retorna ao Buriti Bom para pedir Maria da Glória em casamento, intercalando a perspectiva narrativa de Miguel com o narrador onisciente em terceira pessoa.

O correr desse "riinho", por insignificante que seja, próximo à apresentação de Miguel na abertura da novela, terá, por seu poder evocativo da memória involuntária da protagonista, uma importância caudalosa. Cite-se aqui o contraste deste "fiapo" de rio, correndo entre "miúdas folhagens", com o "belo poço parado" e a sensação de tédio de Lalinha em relação ao Buriti Bom "que se ancorava, recusando-se ao que deve vir" (B, 191). A jovem citadina, recém divorciada de Irvino, filho do patriarca Liodoro, é trazida pelo sogro à propriedade rural, na esperança de que o rapaz retorne e refaça os laços matrimoniais. O narrador, ao registrar o sentimento de Lalinha em relação à fazenda, pontua: "Ali, nada se realizava, e era como se não pudesse manar". (grifo nosso) Isto, para não mencionar o aspecto redundante da expressão "poço parado". 5

Este é um pequeno exemplo da menção ao elemento líquido, atrelado à apresentação e caracterização dos protagonistas, e sua função estruturante dentro da narrativa. Caracteriza-se o choque entre a beleza deste lugar propício ao fantástico, ao extra-ordinário, aproximado a um poço parado e a chegada de um elemento que perturba o equilíbrio estático reinante na fazenda, por obra do acaso, mas certeiro como a correnteza de um rio, trazendo novas possibilidades.

\footnotetext{
${ }^{5}$ Cabe lembrar a relação entre este "riinho" que introduz o fluxo associativo de Miguel com o riachinho de "Uma estória de amor" que, segundo o estudo de Sandra Vasconcelos, Puras misturas, metaforiza o fio das estórias a correr de forma incessante, mesmo ante a ameaça do rio secar em definitivo.
} 
O poço que produz a lenda aproxima-se mais do mito bíblico - e, portanto, do tempo mítico - contrapondo-se ao tempo histórico, representado pelo riozinho que prenuncia a chegada de Miguel e a consequente mudança no modus vivendi dos personagens que habitam a propriedade. A intenção de Miguel ao retornar para o Buriti Bom é pedir Maria da Glória em casamento, abrindo um "canal” para o fruir da água estancada - estagnada? - do "poço parado".

Em outro ponto o narrador observa que a água é marcada pela polaridade alegre/triste: "Triste é a água e alegre é" (B, 132). Esta é uma das muitas ambiguidades que marcam a matéria líquida, somando-se à dualidade fluir/estancar.

As marcas da tristeza, do estancamento, multiplicam-se ao longo da história quando o foco narrativo se aproxima de Lalinha e seu monólogo interior.

Muito da força do elemento água, e seu caráter eminentemente dual, pode ser pensado com o auxílio do trabalho de Bachelard. Se, por um lado, parece consenso pensar a água como fonte de vida, não se pode deixar de considerar este mesmo elemento como "suporte material da morte". Partindo do mais básico senso comum, a água pode gerar a vida, mas pode também afogar.

Quando se pensa na contraposição acima exposta do fluir do rio com a estagnação do poço, pode-se considerar um sentido ainda mais profundo para a impressão negativa de Lalinha, de acordo com o pensamento de Bachelard (1997, p. 67), que escreve: “as águas imóveis evocam os mortos porque as águas mortas são águas dormentes".

Evidencia-se, portanto, de maneira ainda mais contundente, o sentimento de Lalinha registrado pelo narrador, sendo possível afirmar que sua permanência ad infinitum no Buriti Bom equivaleria a uma sentença de morte. Mesmo antes do sentido da estagnação do tempo, no qual nenhuma nova perspectiva se dá para esta personagem, a própria natureza, na figura do Brejo do Umbigo - união da água com a terra - serve para caracterizar parte significativa do Buriti Bom como local da emanação da morte.

Ponto de união, ou comunicação do elemento água com o universo vegetal é, justamente, o buriti. "O buritizal, acolá, impunha seu estado aquoso, os buritis eram demoradamente femininos." (B, 128) Por este trecho, estabelece-se tanto a união entre a água e as plantas - que merecerão um estudo à parte - quanto a chave para entender parte das longas reflexões de Lalinha na segunda parte de "Buriti". A água se impõe não 
apenas como elemento ligado à feminilidade como também aquele que melhor propicia o estado reflexivo ao qual Leandra se entrega, como no trecho analisado abaixo.

Pouco depois da visita da pseudo-feiticeira Do-Nhã, o narrador acompanha Lalinha, que se enclausura em seu quarto, e se surpreende com seu próprio choro: “Cerrou as pálpebras - a noite era uma água”. (B, 163). A noite e o silêncio - elementos também decisivos e que serão investigados no próximo capítulo - unem-se à água e formam uma massa, um todo praticamente indissociável, estando Lalinha no centro, a se debater, como no olho do furacão. "E assim, o silêncio da casa do Buriti Bom - que era como levantada na folha de uma enorme água calma”.(B, 164)

De seu mergulho em si mesmo, com "o abrir-se de outros olhos" (B, 163), na escuridão úmida da noite, Lalinha comprova o que pouco antes notara: "Agora, descobrira que tinha poros que ela mesma ignorava" (B, 160, grifo meu). Estranha num ambiente estranho, ela, assim como o jardim, se dá conta dos fenômenos singulares que fazem parte da noite daquele sertão:

Abaixo, quase de o poder tocar com os dedos o pobre jardinzinho, atulhado, de suas flores dava o ar, das que para desabrochar escolhem o escuro. (B, 164, grifo nosso)

Deitada, uma das mãos estava sobre um seio, sentia o liso de seu corpo como se apalpasse um valor. Sabia-se bela, desejável. (B, 164)

E ouvia. Ouviu. Era um rumor de cavaleiro chegando, estacara encostado aos pilares da varanda. [...] Mas era iô Liodoro, retornando [...] Iô Liodoro, infatigável no viver, voltando do amor de cada dia, como de um trabalho rude e bom. (B, 164/165)

Ponto culminante da reflexão, envolta pela ambiência sensual de plantas e águas que brotam da noite, Lalinha, entregue ao devaneio registrado pelo narrador, pode reconhecer em si o que até então estava apenas subentendido:

Alongou-se, seus pés um no outro descobriam uma suavidade sutilíssima, ah, gostaria de ser acariciada. Voltou-se para o canto, o rosto próximo da parede - a camada de ar ali como que se guardava mais fresca, e com um relento de limo, cheiro verde, quase musgoso, ora lembrava água em moringa nova. Respirava um barro. Sorveu aquilo, dava-se a um novo bem-estar. Pudesse, estaria deitada junto de Maria da Glória, queria que Maria da Glória, horas sem tempo, a abraçasse e beijasse, lhe desse todos os afagos, como se ela, Lalinha, Lala, fosse uma menina, um bichinho, diminuindo, cada vez mais diminuindo, até meio menos não existir, e dormir - só um centro. Dividiu-se - e, mal manhã, as muitas vacas berravam. (B, 165 - grifos meus) 
Considerando as citações feitas acima, parece nítido o tom de progressiva saturação, num continuum que, iniciado nas lágrimas de tristeza e perplexidade de Lalinha, deságuam na percepção disto que os "poros" acabam por revelar, não sem a ajuda desta umidade que a cerca ${ }^{6}$.

Levada pelo fluxo de suas divagações, mesclada às sensações de seu ambiente embebido de limbo, musgo e barro e que contribuem para que ela experimente um novo "bem-estar", diluem-se as resistências e dá-se, finalmente, a captação, pelo narrador onisciente, do desejo - e sua quase inevitável lubricidade - em relação a Maria da Glória. A filha de Liodoro, bela e exuberante, torna-se amiga íntima de Lalinha. A proximidade entre ambas, suas conversas e confidências compõem parte significativa da segunda parte da novela, que mescla a narração em terceira pessoa com a perspectiva de Lalinha.

Embalada em seu devaneio erótico, Lalinha adormece e registra-se uma emblemática divisão. Carregada de ambiguidade, este "Dividiu-se" pode indicar muitas coisas, tanto a passagem ao mundo dos sonhos, quanto a mera divisão entre a noite que se encerra e o dia, anunciado pelo berro das muitas vacas.

A julgar pela proximidade dos registros noturno e diurno, entremeados pelo aprofundamento do sono e a indicação de um sonho - "como se ela, Lalinha, Lala, fosse uma menina, um bichinho, diminuindo, cada vez mais diminuindo, até meio menos não existir, e dormir" - pode-se afirmar que, no mínimo, a "divisão" reforça aquilo que ela deve esconder dos outros habitantes da casa e admitir, por enquanto, apenas para si mesma. Caberá a Lalinha, até certo ponto da narrativa, manter intacta a posição de eterna esposa à espera do marido, até que outros acontecimentos venham a minar essa condição, deixando transbordar o que, por enquanto, deve permanecer represado.

\section{3 - Água e terra: brejo, árvores e flores}

Ponto máximo da emanação da umidade, da mistura da água com a terra, é a "Baixada", o Brejão do Umbigo, próximo, por sua natureza, ao "charco" referido por Bachelard. Ao se aproximar dali, constata-se: "Todo um país de umidade, diverso, grato e enganoso, ali principiava." (B, 124)

\footnotetext{
${ }^{6}$ Cabe assinalar, lembrando o estudo pioneiro de Luiz Costa Lima, "O Buriti entre os homens ou o exílio da utopia", que Leandra, também é chamada de Lala, que significa "várzea", aumentando a conotação da união da terra com a água e a fertilidade, conforme COSTA LIMA, 1974, p. 141.
} 
A mesma umidade e união entre os elementos terra e água se encontram "no dia da Criação", na tradução de Haroldo de Campos (2004, p. 49): "E uma névoa / ia subindo da terra / E umedecia / toda a face da terra-húmus [...] E um rio saía do Éden / para umedecer o jardim".

A associação do Brejão com o sexo e a morte, por sua vez, é inevitável. Noticiase que, nas beiradas deste pântano não se pode dormir, uma vez que certo "gás de vício" tem poder letal - ou pelo menos adoecedor - sobre os que ali se atrevem a repousar. "O brejo matava"(B, 138).

Da mesma forma, no entanto, ali crescem "Flores que deixam o grude dum pó, como borboletas pegadas; cheiram a úmido de amor feito. Ninguém separa essas terras dessas águas.” (B, 137)

Gaston Bachelard, em seu livro A água e os sonhos, obra bastante significativa para iluminar esta noite úmida que é "Buriti", aponta para o "casamento" de certos elementos materiais. Trata o autor da união, da fusão destes elementos, no caso a água e a terra, e de como isto pode ser entendido no plano literário.

Bachelard escreve:

desde que duas substâncias elementares se unem, desde que se fundem uma na outra, elas se sexualizam. Na ordem da imaginação, ser contrárias para duas substâncias é ser de sexos opostos. Se a mistura se operar entre duas matérias de tendência feminina, como a água e a terra, [...] uma delas se masculiniza ligeiramente para dominar sua parceira. (1997, p. 100)

Resultado dessa união indissociável é a fecundidade contínua do solo. Para Bachelard (Idem, p. 115): "é o casamento substancial da terra e da água, realizado no charco, que determina a potência vegetal anônima, gordurosa, curta e abundante." O sentido deste "casamento" se desdobra até o pensamento de Vovó Maurícia - mãe de iô Liodoro - na lembrança de Maria da Glória, quando ela afirma que "a gente se casa será é para lua-de-mel e luas-de-méis!...” (B, 160). Vê-se que a lua de mel, em "Buriti", é praticamente infinita, pois quando não se concretiza no encontro dos amantes, esta se consuma na própria condição de existência do lugar.

Note-se que estamos ainda naquele mítico dia da criação, para pensar com Gunter Lorenz. Pois é da união do pó, da "terra-húmus" com o sopro divino ("O-NomeDeus [...] inspirou em suas narinas o respiro dos vivos") que nasceu o homem.

O Brejão situado no umbigo/centro do jardim do demiurgo Rosa propõe uma profunda reflexão sobre isto de que o homem é feito, a união entre a terra-húmus e a 
umidade do sopro divino. Ao mesmo tempo, impõe-se o choque entre isto que o homem tem de mais primitivo e sua atualidade histórica e cultural.

Do casamento entre água e terra, da matéria orgânica de fecundidade sem fim, nasce uma natureza exuberante, que a todo instante remete e evoca o infinito ciclo de casamento/reprodução de todas as espécies ali plantadas, a começar pelas vegetais.

Este casamento primeiro, material, elementar, telúrico, será ocasião para outros tantos casamentos no decorrer de "Buriti". Para ser mais preciso, do ponto de vista da constituição da narrativa, o Brejão-do-Umbigo, por aquilo que ele é dentro da "natureza" do texto, está carregado de uma simbologia erótica que, em instantes específicos da narrativa, se unirá com as personagens em certos momentos críticos nos quais estas se encontram. Isto sem falar na imagem criacionista do "umbigo", seja como cordão umbilical cortado ao nascer, seja como umbigo do mundo, ponto último inacessível.

A indissociabilidade entre homem e natureza na obra de Guimarães Rosa, análoga à da terra com a água, por exemplo, encontra respaldo no pensamento de Mônica Meyer (2008, p. 192). Para esta autora:

A natureza para Guimarães Rosa não se apresenta como um espetáculo ou uma coleção de aspectos naturais compondo um cenário ou um palco, onde se desenrola a aventura da viagem. A natureza não está longe, nem fora [...] O ambiente/sertão não está separado das pessoas, dos bichos, das plantas, e sim dentro de cada um, caracterizando o jeito de ser e de viver. "O sertão é dentro da gente.

Notar-se-á, portanto, um constante trânsito entre os aspectos naturais que se humanizam e os homens e mulheres que se naturalizam. Ao final de "Buriti" o narrador sintetiza esta condição: "as pessoas - baile de flores degoladas, que procuram suas hastes." (B, 250)

Nesse jogo de constante intercâmbio do humano que se vegetaliza e do vegetal que se humaniza, ressoa o mito platônico dos seres andróginos, separados por Zeus, e condenados a uma infindável busca por sua metade correspondente. Na expressão de Rosa, afeita aos propósitos de sua obra, estes seres são "flores degoladas", peças que compõem o Corpo de baile do qual "Buriti”, em sua edição original, é o desfecho.

Importante notar que, segundo Platão (1983, p. 23), a raça dos homens "era descendente do sol, o feminino da terra e o que tinha de ambos era da lua, pois também a lua tem de ambos". A ambiência de "Buriti" é basicamente noturna, com inúmeras 
menções à lua, dentre as quais se destaca a morte de Maria Behú - filha beata de Liodoro, sem atrativos físicos e imersa em rezas e penitências - na lua nova, que designa uma virada nos acontecimentos da narrativa, como a perda da virgindade de Maria da Glória e o encontro amoroso de Lalinha e Liodoro.

A regência lunar, portanto, afeita à busca desta união mítica, é outro elemento natural indispensável para a compreensão da novela, sendo necessário seu pleno desenvolvimento, junto com a figura da noite, em capítulo posterior.

\section{4 - Brejo masculino: árvores.}

Miguel e nhô Gualberto, a caminho da fazenda do Buriti Bom, após passarem por um lugar denominado Alto Grande, aproximam-se do Brejão do Umbigo.

A mata marginal se cerrava, uma enormidade, negra de virgem. [...] Aquelas árvores de beira-de-rio, maculadas, barbudas de branco, manchosas, cascudas com rugas, eriços, placas e pálidas escamas se pintalgando - a carne de vaca, a marmelada de cachorro, o jequitibá, o landí, o ingá, a almesca, o gonçalo, o pau-pombo, a folha miúda, o olandim-do-brejo pardão tomavam tamanhos fora do preceito, bojavam diâmetros estrusos. [...] Lá dentro, se enrolava o corpo da noite mais defendida e espessa. O chão, de impossível andada, era manta profunda, serapilheira em estrago e empapo, se amassando numa lama vegetal. No denso, no escuro, cogumelos e larvas olhavam suas luzinhas mortiças. Lívidos entes se encostavam, sem caras. Miguel esperou. Devagar, recuava. Tragava o medo do mato. (B, $124 / 125$ - grifos nossos)

A seriação das "árvores de beira-de-rio", bem como a listagem de seus qualificativos, faz lembrar as seriações encontradas em Macunaíma ${ }^{7}$ e podem passar despercebidos como apenas mais uma lista de nomes e características de árvores, mera demonstração de conhecimento de botânica sertaneja. Mas a curiosidade aguçada pode levar mais longe, para, numa investigação mais detida, conhecer melhor cada espécie e perceber a função de sua disposição neste trecho em específico.

Numa breve apreciação, constata-se que as dez "árvores de beira-de-rio" caracterizam-se como madeiras de lei, que primam por sua dureza e durabilidade. Como

\footnotetext{
${ }^{7}$ A aproximação do texto de Rosa com a rapsódia modernista pode ser feita pelos detalhes, como no caso da serapilheira - citada acima - presente no texto de Mário de Andrade no momento em que Sofará coloca o pequeno Macunaíma nos "carurus e sororocas da serrapilheira" fazendo o infante crescer e virar "um príncipe lindo" (ANDRADE, 1978, p. 11), evidente evocação da masculinidade viril, como no trecho destacado de "Buriti".
} 
se não bastasse sua grandeza natural, no texto estes espécimes ainda "tomavam tamanhos fora do preceito, bojavam diâmetros estrusos". São apresentadas no texto, de forma sequencial, numa somatória de elementos que, perfilados, reforçam as qualidades que estes espécimes têm em comum.

Estas árvores evocam ainda o nome de homens, como "gonçalo", árvore que também é conhecida como "quebra-machado". Importante ainda o caráter de serem produtoras de resinas aromáticas e do "fruto úmido", no caso do ingá. Da almesca, também conhecida como almecegueira, extrai-se o almíscar, que traz em sua raiz a palavra persa, musk, testículo. Pode ainda se notar, quanto à "marmelada de cachorro", um dos sentidos coloquiais para "marmelada", qual seja: "troca de ternuras ou intimidades amorosas" (HOUAISS, 2001, p. 1856).

Portanto, num trecho em que o brejo é visto pela perspectiva masculina, enumeram-se árvores de tronco "fora do preceito", evocando a virilidade, as "potências machas", com seus atrativos próprios.

Dos elementos mais evidentes àqueles mais escondidos, parece inequívoca a multiplicação do erotismo pelo texto - via sexualização da natureza - principalmente numa passagem que pareceria meramente descritiva, simples anotação dos espécimes vegetais da região. Mais uma vez nota-se, como já fizera Antonio Candido, que em Guimarães Rosa, mais do que trazer a cor local, trata-se de uma composição que extrapola o "típico" da região, prevalecendo a evocação de um conteúdo simbólico naquilo que pareceria apenas mais um cenário da ação.

Ponto máximo dessa emanação erótica vegetal e o elemento masculino é o caso de iô Liodoro. O proprietário do Buriti Bom, viúvo de Iaiá Vininha ${ }^{8}$ (B, 228), pai de Irvino, Ísio, Behú e Glorinha, é conhecido por sua intensa atividade erótica, com suas rotineiras cavalgadas noturnas para encontrar as amantes, enquanto mantém uma moral conservadora no interior de sua casa. Esta personagem é aproximada ao buriti grande, aproximação primeira e mais evidente, em vários pontos da narrativa, sugerindo uma

\footnotetext{
${ }^{8}$ Vide em "O recado do morro" a menção à fazenda da "dona Vininha, fazenda do Bõamor" (ROSA, 1969, p. 38), uma das propriedades visitadas pela comitiva guiada por Pedro Orósio. Embora os títulos honoríficos variem ("dona"/ "Iaiá"), o apelativo permanece. Vide ainda a proximidade na significação dos nomes das propriedades "Bõamor", corruptela de "Bom amor" e o "Buriti Bom". Considerando legítima, dada a pregnância simbólica do buriti na obra de Rosa, fazer a aproximação entre a palmeira sertaneja "buriti" - e o "amor", teríamos o seguinte desdobramento: Bõamor/Bom Amor/Bom Buriti/Buriti Bom.
} 
quase total identificação entre o chefe da casa e a palmeira desproporcional que reina no terreno.

Não resta dúvida de que o ponto alto desta flora sui generis que constitui o texto de "Buriti" é o "buriti-grande", "erecto, liso, o estipe - a desnudada ponta" (B, 104), palmeira (feminina) de aspecto fálico (masculino) cravada no terreno. Esta planta desproporcionalmente grande, firmemente presa ao terreno e que se ergue a altura "de setenta ou mais metros”, cujas emanações eróticas se fazem sentir nas saídas noturnas de iô Liodoro, atrás de suas "mulheres exatas", parece unir céu e terra, os aspectos mais elevados aos mais baixos do amor.

No entanto, outras menções aos elementos vegetais são menos comentadas pela crítica e merecem aqui estudo minucioso, para que se tenha uma noção mais precisa da relação entre a construção/descrição do espaço e os movimentos, externos e internos, tanto de iô Liodoro quanto das demais personagens.

Segue-se aqui, na realidade, uma pista deixada pela pioneira observação de Paulo Rónai em relação ao buriti grande. Ao marcar a singularidade desta "árvore gigante" o crítico escreve: "ao caracterizar a personagem vegetal, (Rosa) está definindo uma das funções, talvez a mais importante, da própria arte." (RÓNAI in ROSA, 2006, p. 19 - grifo nosso )

Ainda que num texto no qual aprecia o Corpo de baile de forma genérica, a percepção é certeira. O buriti grande é, apesar do status vegetal, ou justamente por causa dele, personagem importante da narrativa, devendo ser levada em conta sua ação sobre os demais. Focar a análise na constituição da flora de "Buriti" não é, portanto, nada mais do que atentar para outros personagens que ali se encontram, interagindo com os personagens humanos, sob a tônica das emanações eróticas desta grande palmeira.

Portanto, a identificação do patriarca com a vegetação local prossegue ao longo da novela: "ele era meio dos Gerais e dali - de seus matos, seus campos, feito uma árvore". (B, 228), ou "Modo estranho, em iô Liodoro, grande, era que ele não mostrava de si senão a forma. Força cabida, como a de uma árvore".(B, 132)

É legítimo ainda refletir sobre o caráter ancestral e mítico da presença das árvores e palmeiras - no caso o buriti - ao longo de toda a narrativa. Sendo evidente a referência ao Jardim do Éden, as árvores e todos os outros elementos do mundo vegetal são testemunhas e atores desta criação e de seu caráter cíclico. Dentre outros dados 
objetivos, oriundos da Botânica, é fato de que muitos destes espécimes podem viver por milhares de anos.

Em "Buriti", Rosa dota a natureza de uma ampla eroticidade, cria um ambiente de plantas e solo pleno de características plásticas e sonoras que proporcionam invulgar participação na dinâmica maior da novela. Os homens e mulheres inseridos neste "lugar de agrado", natureza finamente construída pelo autor, recebem a influência deste jardim e têm a ocasião para manifestar, em consonância com a ancestral fertilidade local, seu próprio erotismo. Pela ação do escritor - ou seja, por meio do uso da palavra em sua máxima virtualidade criativa - o corpo da natureza, "corpo da noite", se erotiza a ponto de afetar o corpo das personagens.

Adélia Bezerra de Meneses (2010, p. 60), retomando o pensamento de Giambattista Vico, aponta para o processo de animização da natureza em seu estudo sobre Grande sertão: veredas. A menção ao filósofo napolitano não poderia ser mais pertinente, pois Vico associa a origem da linguagem poética com os primórdios da capacidade humana para nomear os fenômenos da natureza, usando a si próprio - o homem - como medida.

Em Vico (1974, p. 43), lê-se o seguinte: "Os homens ignorantes das razões naturais que produzem as coisas [...] transferem para as coisas a sua própria natureza [deles, homens], assim como quando o vulgo afirma que o ímã está enamorado pelo ferro". Tomando o próprio corpo como referência, inicia-se o processo pelo qual o homem, poeticamente, passa a nomear os fenômenos que o rodeiam. De novo Vico (Idem, p. 50): “A mente humana inclina-se, naturalmente, mediante os sentidos, a fazerse visível no corpo.” Estaria aí, segundo este filósofo, "o universal princípio da etimologia em todas as línguas, nas quais os vocábulos são transpostos dos corpos e das propriedades dos corpos para a significação das coisas da mente e do espírito."

Nada mais apropriado, para uma narrativa que tanto se refere à origem dos tempos, refletir sobre a origem da linguagem poética, tão cara a Rosa. Ao modo de Vico, pode-se identificar uma forma do trabalhar do escritor mineiro, na medida em que este faz a natureza impregnar-se do que é propriamente humano, daí a liberdade de se cunhar o termo erotismo natural, síntese possível do labor poético do autor. Em "Buriti", este procedimento parece ser maciço, a ponto de se fazer acreditar que o erotismo - presente em toda parte - nasce na natureza, sendo o humano decorrência "natural" do que se observa em redor. E, ao final, este paradigma legitima o erotismo 
como modo de ser constitutivo do humano, posto que nascido na origem da própria natureza. Tudo isso só é possível, nunca é demais lembrar, pela singular instância narrativa que caracteriza "Buriti", na escolha da palavra empenhada em criar um ambiente extra-ordinário, literariamente rico e pleno de possibilidades interpretativas.

Se as referências ao Éden bíblico apontadas no começo deste texto têm sentido em serem destacadas, eis o porquê, uma vez que o barro tornado homem traz, por definição em sua essência, o infinito pendão à abundante fertilidade - natural - que se expressará - humanamente - no encontro com o outro.

\section{5 - Brejo feminino: flores.}

“Há flor sem amor?”( ROSA, 1970, p. 256)

Como se não bastasse a evocação das árvores e as "forças machas" $(\mathrm{B}, 113)$ correspondentes, deve-se observar que o mesmo Brejão, de acordo com perspectiva distinta, pode evocar o sentido complementar da feminilidade.

A visão do Brejão pelo ângulo feminino se dá após o primeiro encontro noturno de Lalinha com iô Liodoro, no qual o patriarca delicia-se ao passear seus olhos pelo corpo de Leandra ("Sua beleza era pasto" (B, 220 - grifo nosso), enquanto esta se delicia em mostrar-se. Ao amanhecer, Lalinha deseja sair para passear pela propriedade.

Logo ao acordar, abrindo a janela do quarto, ela se depara com o "jardinzinho", "ao pé da janela, viçoso de verdes hastes." Lalinha pede para "ir até a Baixada", ao "bom e belo [...] Brejão", com suas "grandes dadas flores: a olímpia, a dama-do-lago, a gogóia, o golfo-da-flor-branca, a borboleta, a borboleta-amarela, as baronesas. O brejo alegrava, se doava, doce como o ócio e o vício.” (B, 218)

Permanece, em relação ao trecho das "árvores de beira-de-rio", o sentido da desproporcionalidade. Ali, os troncos das árvores, excessivamente grandes, são "fora do preceito". Aqui, as “dadas flores” são "grandes”.

O brejo não causa temor, como na perspectiva de Miguel, que se aproximava de um ambiente estranho, desconhecido. Aqui, o brejo é alegre, reverberando o estado de espírito de Lalinha, que "se doava", e é convidativo, "doce como o ócio e o vício". Mesmo assim, não deixa de ressoar o caráter mortal do "gás de vício", ampliando ainda mais as ambiguidades desta passagem.

Neste ambiente de alegria e doação, as flores, assim como as árvores, são enumeradas, certamente não ao acaso.

A "olímpia", Rosa (2003, p.118) explica a Edoardo Bizarri, também pode ser chamada de "lírio do brejo, golfão branco", "um nenúfar da Ninfeáceas". Quanto à 
"gogóia", o autor afirma que "é o mesmo que baronesa", para logo ampliar o leque de opções “umas ninfeáceas, também [...] (rainha-do-lago, gólfão, jijoga, água-pé, guapé, uapé)"

A borboleta e a borboleta amarela, segundo o Houaiss, podem ser o mesmo que lírio-do-brejo, além de outra espécie de flor ornamental, originária do Chile, menos provável de ser encontrada no sertão. Note-se ainda que o termo borboleta, no sentido figurado, pode significar "vulva", e até "indivíduo que se prostitui". Não por acaso, Lalinha, em sua relação com a personagem iô Liodoro, mais tarde se comparará a uma prostituta. Lalinha "queria ser flor, toda coqueteria sinuasse em sua voz" (B, 216)

Quanto ao "lírio do brejo", variação de "olímpia", é ampla a significação e importância erótica desta espécie. Vale notar que uma das sinonímias para o "lírio" é "açucena", que é um dos apelativos da personagem Doralda, ex-prostituta protagonista de "Dão-Lalalão", novela que integra o mesmo Corpo de baile. Quanto à planta em si, Sangirardi Jr. (1981, p. 180) faz notar que o lírio, "para a mulher, é planta de ação anafrodisíaca, combatendo a ninfomania ou o furor uterino". Este autor ainda frisa a simbologia da flor relacionada à pureza de alma, além de estar associada à morte e à proteção contra as bruxas e seus encantamentos.

Constata-se facilmente, ademais, que em sua apresentação das flores que povoam o Brejão "feminino" Rosa situa-as quase todas na mesma família, as Ninfeáceas.

Esta espécie de vegetal aquático, cujo nome científico obviamente deriva das criaturas míticas ligadas à água, tem sua própria história e significado dentro do imaginário erótico. Plínio (1992, p. 191 e 335) trata da origem das ninfeáceas, anotando que a flor nasceu de uma ninfa que morreu de ciúme por Hércules, sendo por isso também chamada de "heracleon" ou ninfeia heráclia. Este autor ainda expõe que a raiz desta planta, que tem a forma de uma clava, pode ter ação inibidora sobre a potência e a procriação, ou mesmo sobre os sonhos eróticos. Em pesquisas posteriores, Sangirardi Jr. (Op. Cit., p. 156) anota que, por ser uma planta aquática, há que se considerar seu valor para apagar "os incêndios dos sentidos".

Ainda sobre as ninfeáceas, o mesmo Sangirardi Jr. cita Dioscórides para o qual a ação da raiz desta espécie, quando "bebida com muita frequência, em pouco tempo torna cabisbaixo e sem brio aquele membro que honestamente não se pode nomear" (Idem, p. 158/159). Curiosamente, Rosa utiliza substantivos bastante incomuns para 
designar "aquele membro", como "estrovenga" ou mesmo "mêntula", numa passagem que evoca uma figura da mitologia indígena, o Curupira, que se caracteriza, entre outros atributos, por sua "mêntula desconforme, submetendo as ardentes jovens, na cama das folhagens, debaixo do luar" (B, 126)

Vê-se, portanto, que a sequência deste encontro já pleno de calor erótico - "os olhos e as palavras dele quentemente a percorriam" (B, 216 grifo nosso) - tem a função de "esfriar os ânimos", sendo toda ela remetida ao frio da manhã e às propriedades das flores do brejo para conter o desejo sexual.

Se as árvores se erguem em direção ao céu, recebendo mais diretamente os raios solares, as plantas aquáticas, como o próprio nome sugere, enraízam-se no elemento líquido, aproximando-se, por sua natureza, mais da água que do sol.

Bachelard (1997, p. 145), ao discutir a questão da pureza das águas, trata também de seu oposto, as águas impuras, impróprias para o consumo humano. Como se viu, o Brejão é caracterizado por sua união entre água e terra, guardando em si uma face mortífera.

Ao tratar da flora que brota deste ambiente particular, este mesmo autor escreve:

Para certas almas, a flora das águas é um verdadeiro exotismo, uma tentação de sonhar algures, longe das flores do sol, longe da vida límpida. Numerosos são os sonhos impuros que florescem na água, que se exibem pesadamente sobre a água, como a grossa mão espalmada do nenúfar. (Op. Cit. P. 146)

Admirar a vegetação do Brejão é, portanto, contemplar as "flores do mal", num sentido mais próximo da materialização vegetal disto que nasce de um meio impuro e, mais, que tira muito de sua beleza e exuberância da água impura e putrefata, beleza que encobre o mal submerso.

Georges Bataille, em seu texto A linguagem das flores reflete sobre o aspecto visual das plantas e suas partes. Para o pensador francês (2007, p. 92), desfazendo as idealizações que giram em torno da beleza das flores, não é só a raiz, "contrapartida perfeita das partes visíveis da planta, [...] apaixonadas pela podridão como as folhas pela luz", mas as próprias flores que podem, num exame cuidadoso, revelar uma contraface pouco agradável. Para Bataille, mesmo "as flores mais bonitas se enfeiam no centro com a mancha felpuda dos órgãos sexuais. É assim que o interior de uma rosa não responde de maneira nenhuma à sua beleza exterior [...] a flor é traída pela fragilidade de sua corola." (Idem, p. 90) 
A menção a Bataille, aqui, convém por ampliar o espectro interpretativo. O texto de Rosa insiste muito mais na beleza e exuberância das flores que no seu potencial aspecto repugnante. Esta, a repugnância, fica circunscrita ao brejo, no qual fertilidade e podridão parecem coincidir. Para o pensador francês, vale demarcar o movimento sincrônico em direções distintas, as folhas e flores indo para o alto iluminado e as raízes rumo ao solo - charco - e à podridão da matéria decomposta. E é este movimento que pode ser identificado em "Buriti". Embora o escritor mineiro insista na exuberância das flores, que não será, certamente, eterna, este não deixa de mencionar a simultaneidade e a dependência das flores em relação à sordidez do brejo.

Portanto, a união das substâncias elementares, água e terra, exposta acima de acordo com Bachelard, encontra aqui, no tratamento da flora, um desdobramento possível. O Brejão é ocasião para o encontro do par de opostos puro/impuro.

As flores, ninfeáceas, brotam graças à união da água com a terra, num meio impuro. Ao mesmo tempo, retomando o pensamento de Heloísa Vilhena de Araújo em seu A raiz da alma (1992, p. 144), temos que Maria da Glória e Lalinha "são ninfas em casulo - em reclusão - transformando-se [...] em borboletas, em insetos adultos, perfeitos, formando toda a beleza que lhes era destinada".

A presença das ninfas, criaturas intimamente ligadas à água é, para Bachelard (1997, p. 150), sinal da pureza deste elemento: “a água purificada é ninfeizada”. Sob essa perspectiva, fica nítida a multiplicação das ambiguidades do texto, ali onde, a princípio, não haveria mais do que uma descrição/composição do ambiente, aparentemente acessória ao desenrolar da trama.

Multiplicam-se ainda os sentidos dos elementos eróticos, retomando o que já fora dito sobre as borboletas - flores - aqui somadas ao raciocínio da estudiosa brasileira que aproxima as personagens femininas a borboletas - animais - em estado de desenvolvimento, para o pleno desfrute da sexualidade.

As ninfas, assim como a própria Afrodite, aparecem na Mitologia Grega como um dos primeiros resultados da castração de Urano por Cronos. Lê-se em Hesíodo, na tradução de Jaa Torrano (2007, p. 111 a 113):

E do pai o pênis ceifou com ímpeto e lançou-o a esmo para trás. Mas nada inerte escapou da mão: quantos salpicos respingaram sanguíneos a todos recebeu-os a Terra; com o girar do ano gerou as Erínias duras, os grandes Gigantes rútilos nas armas, com longas lanças nas mãos, e Ninfas chamadas Freixos sobre a terra infinita. [...] 
O pênis, tão logo cortando-o com aço atirou do continente no undoso mar, aí muito boiou na planície, ao redor branca espuma da imortal carne ejaculava-se, dela uma virgem criou-se. Primeiro Citera divina atingiu, depois foi à circunfluída Chipre e saiu veneranda bela Deusa, ao redor relva crescia sob esbeltos pés. A ela. Afrodite Deusa nascida de espuma e bem-coroada Citeréia apelidam homens e Deuses, porque da espuma criou-se [...] e Amor-do-pênis porque saiu do pênis à luz. Eros acompanhou-a, Desejo seguiu-a belo, tão $\operatorname{logo}$ nasceu e foi para a grei dos Deuses. Esta honra tem dês o começo e na partilha coube-lhe entre homens e Deuses imortais as conversas de moças, os sorrisos, os enganos, o doce gozo, o amor e a meiguice. (grifos meus)

Dizer de Maria da Glória que esta se aproxima da própria Afrodite não é, portanto, descabido: "Sendo o sertão assim - que não se podia conhecer, ido e vindo enorme, sem começo, feito um soturno mar, mas que punha à praia o condão de inesperadas coisas, conchinhas brancas de se pegarem à mão, e com um molhado de sal e sentimentos. De suas espumas Maria da Glória tinha vindo - sua carne, seus olhos de tanta luz, sua semente" (B, 195/196, grifos meus).

A referência às ninfas, além da evocação vegetal e dos seres míticos, ligadas à água, remete ainda a um dos significados do termo ninfa: pequeno lábio da vulva. Esta observação, numa pequena nota de rodapé do importante trabalho de Heloísa Vilhena de Araújo (1992, p. 145), reforça ainda mais a ideia de que a disposição dos espécimes vegetais, seu pleno vigor erótico e sua relação com as personagens e a trama, muitas vezes podem passar despercebidos.

\section{6 - O brejo do encontro: terrível delícia}

Numa passagem semelhante à da aproximação de Miguel e nhô Gualberto do brejo, destacada acima, quase como num jogo de espelhos dentro da narrativa, Maria da Glória e Lalinha, também a cavalo, num passeio pela propriedade, aproximam-se da "Baixada".

Para espantar os mosquitos, Lalinha acende um cigarro a pedido de Maria da Glória, que também resolve fumar. Lalinha se surpreende com a iniciativa da cunhada em fumar, e acaba ouvindo a seguinte confissão: “Tem horas, vou contar a você: fico pensando que não presto - que o diabo me tenta... Porque acho que tudo o que tem, de melhor, é o que a gente não deve de fazer, o que é preciso se aproveitar escondido, bem escondido..." (B, 171/172). 
Em meio ao clima de confissão de uma e surpresa da outra, permeado pelo desejo do que se pode aproveitar escondido, sendo isto o "de melhor", avista-se, mais uma vez, o Brejão-do-Umbigo:

O nome era quase brutal, esquisito, desde ali pouco se principiava, no chão - um chão ladrão de si mesmo - até lá, onde $\mathrm{o}$ rio perverte suas águas. $\mathrm{O}$ que se sabia, dele, era a jangla, e aqueles poços, com nata película, escamosa e opal [...] $O$ brejo não tinha plantas com espinhos. Só largas folhas se empapando, combebendo, como trapos, e longos caules que se permutam flores para o amor. Aqueles ramos afundados se ungindo dum muco, para não se maltratarem quando o movimento da água uns contra os outros esfregava. Assim bem os peixes nadavam enluvados em goma, por entre moles, mádidas folhagens. E todos os bichos deixavam seus rastros bem inculcados na umidade da argila. Todo enleio, todo lodo, e lá, de tardinha, a febre corripe, e de noite se desdobra um frio maior, sobre as que se abrem torpes - bolhas do brejo e estrelas abaixadas. Aquilo amedrontava, dava nojo. (B, 172-grifos meus)

O trecho acima, sobretudo o destacado, não deixa dúvida sobre a ligação da flora local e o erotismo, sendo cabível o comentário de que, ali, a própria natureza copula, como sugere o movimento dos "ramos afundados se ungindo dum muco, para não se maltratarem quando o movimento da água uns contra os outros esfregava".

O destaque da análise, aqui, tem o foco no elemento vegetal. Mas percebe-se a dificuldade da tarefa, uma vez que o texto caminha diversas vezes para o plano da fusão de elementos. Lembre-se que se trata de um brejo, lugar onde naturalmente se fundem água, terra, vegetação, restos de plantas e animais, criando um ambiente onde prevalece a mistura, a indissociação, o disforme. A criação rosiana, portanto, à sua maneira, mimetiza o ambiente alagadiço, convertendo em palavras o que é próprio do lugar.

Nessa ambiência de mistura, o texto se compõe de signos essencialmente complexos. Invertem-se os termos positivo e negativo dos elementos da natureza. $\mathrm{O}$ chão não representa a firmeza ou segurança, pois este agora é "ladrão de si mesmo."

O rio, contrariando sua fluidez natural, não verte, simplesmente, mas "perverte suas águas", dando o que pensar sobre o que poderia vir a ser esta "perversão" das águas de um rio. Pode-se supor que Rosa, subvertendo o sentido do termo "perversão", indique a possibilidade deste rio transbordar, numa ligação à abertura de certas personagens em experimentar outras possibilidades que não se limitam a formas conhecidas e aceitas, excedendo os limites deste fluir da sexualidade que se restringe ao "leito do rio" no sentido mais tradicional. 
Os peixes não nadam na água, como obviamente se poderia esperar, mas “enluvados em goma”, por entre as folhagens úmidas (mádidas) e moles. A aproximação dos extremos, tal como o casamento dos elementos materiais e a convivência da pureza com a impureza, ganha agora a convivência do alto com o baixo, seus extremos: "bolhas do brejo" - que se formam e estouram de baixo para cima - "e estrelas abaixadas" - que descem do alto para o baixo. Tudo isso, talvez por seu acúmulo de elementos habitualmente incompatíveis, ao final, suscita o mesmo sentimento da aproximação dos personagens masculinos ao brejo, o medo: "Aquilo amedrontava" (B, 172) “(Miguel) tragava o medo do mato" $(\mathrm{B}, 125)$

Pode-se cogitar que este medo advém justamente disto que o brejo suscita, a saber, a possibilidade da total indiferenciação, da perda de si, dos próprios limites que dão contorno ao sujeito. Note-se, para tanto, as semelhanças presentes nas duas descrições do brejo, a começar pelo chão, "ladrão de si mesmo" (B, 172), "de impossível andada, era manta profunda, serapilheira em estrago e empapo, se amassando numa lama vegetal.” (B, 125) Essas relações pelo avesso talvez possam ajudar a entender a visada de Rosa quanto ao sertão: ele em si já contém seu duplo.

Destaque-se também os animais disformes, de sangue frio, de aspecto repugnante, ou mesmo os peixes que não nadam na água, mas justamente nesse terreno misto: "cogumelos e larvas olhavam suas luzinhas mortiças. Lívidos entes se encostavam, sem caras" (B, 125) "peixes nadavam enluvados em goma, por entre moles, mádidas folhagens" $(\mathrm{B}, 172)$

E é justamente na aproximação com o Brejo, na conjunção de seu potencial repugnante e atraente, belo e terrível, que se destaca a máxima fertilidade do terreno. Deste ambiente repugnante, justamente pelo acúmulo de matéria orgânica em decomposição, o solo dá sinais de vida intensa, noutra passagem repleta de sugestões quanto à atividade erótica na Natureza:

Do Brejão, miasmal, escorregoso, seu tijuco, seus lameiros, lagoas. Entre tudo, flores. A flor sai mais colorida e em mimo, de entre escuros paus, lôbregos; lesmas passeiam na pétala da orquídea $[. .$.$] os caracóis encadeando espíntrias, junto de outras$ flores $(\mathrm{B}, 125)$

O exuberante colorido da flor e seu "mimo" decorrem da escuridão dos paus de onde ela provém. A beleza da orquídea - ela também uma planta de importante uso dentro da botânica erótica, que tanto pode estimular como inibir o desejo sexual - se mistura com a viscosidade da lesma, noutra sugestão libidinosa dos elementos naturais. 
No plano literário, a simbologia sexual relativa à orquídea encontra, no mínimo, uma menção ilustre. Em Proust (2006, p. 291), no volume “O caminho de Swann” a catleia espécie de orquídea nativa do Brasil e outros países sul-americanos - é sinônimo da "posse física" de Charles Swann em relação à demi-mondaine Odette de Crécy, passando a ser corrente a expressão entre as personagens "fazer catleia".

Os caracóis encadeiam-se em múltiplas cópulas, tendo as flores como suporte. Com relação às "espíntrias", além da referência à "lascívia dos movimentos dos caracóis" (ROSA, 2003, p. 115), há sentido dicionarizado de "indivíduo libertino que inventa novas práticas de luxúria, com requintes de voluptuosidade, o que usa fornicação de novo gênero, pederasta" (HOUAISS, 2001, p. 1232), que traz ainda a relação etimológica entre espíntria e esfíncter. A este respeito, outras observações merecem ser feitas.

O termo spintria (plural, spintriae) foi usado pela primeira vez, provavelmente, por Suetônio, autor de Tiberio Calígula, ao tratar do exílio de Tibério na ilha de Capri. Suetônio (1983, p. 137) descreve, aqui na tradução de Oliveri Valls, uma sala preparada para "secretas obscenidades": "Allí, grupos de jovencitas y de jóvenes licenciosos recogidos de todas as partes, junto com esos inventores de monstruosos acoplamientos a los que él llamaba "spintries", unidos em grupos de três, se prostituían entre sí en presencia de él $[\ldots] "$.

Na Roma pré-cristã, do século I a.C., o termo passou a ser usado para designar moedas, que eram utilizadas nos bordéis, para serem trocadas por favores sexuais. Tais artefatos eram feitos de bronze, havendo de um lado uma representação erótica e no outro um número. Acredita-se que o uso destes materiais para a circulação nos bordéis tenha sido decorrente de uma proibição do imperador Tibério de usarem-se moedas com a imagem do imperador nestes ambientes.

Durante o período em que este mecanismo subsistiu, haveria, portanto, uma troca entre a moeda corrente e as spintirae, que depois seriam novamente trocadas pelas moedas.

Tanto o deslocamento do sentido original de spintria - do homossexualismo masculino para as moedas - como sua utilização como a "moeda dos bordéis" é ainda discutida entre especialistas, não havendo plena concordância sobre o assunto (FISHBURN, 2007, p. 230). Escavações recentes em Pompéia, nas Termas Suburbanas, encontraram figuras idênticas às impressas nas moedas. Cogita-se que, contíguo aos 
banhos termais, funcionava um bordel, sendo clara a presença dos motivos eróticos junto às termas. Supõe-se, inclusive que as moedas poderiam ter sido usadas originalmente como fichas para o que seria uma espécie de "armário" onde as roupas seriam guardadas.

De qualquer forma, voltando para o texto de Rosa, é digno de nota que esta incursão por um vasto sertão historicamente pleno de conotação erótica seja possível a partir dos pormenores da obra. Mais uma vez, as indicações de Rosa ao seu tradutor italiano revelam (velam novamente) sentidos possíveis, mas certamente não definitivos, para a urdidura de "Buriti".

Isto porque, além do que o próprio autor indica, a saber os cachos dos caracóis que vão copulando entre si, subentende-se a referência à prostituição masculina. Digno de nota, portanto, o deslocamento do sentido original da expressão dos "inventores de monstruosos acoplamientos" aos caracóis que se encadeiam durante o ato reprodutor. Apazígua-se, numa primeira leitura, o sentido pleno do erotismo da passagem, havendo, talvez, referência a certo asco provocada pelo encadeamento de criaturas gosmentas. Só a pesquisa revela a referência ao espetáculo licencioso que se dava para o deleite do Imperador Romano. De qualquer forma, prevalece a noção de espetáculo erótico, de um fenômeno que se dá a ver, seja no plano da natureza - os caracóis copulando - ou na sala preparada - ambiente privado - para a realização da orgia.

Estabelece-se aqui, uma vez mais, a dinâmica entre o detalhe do texto e o todo da obra, da mesma forma que se pode observar a plenitude das referências eróticas tanto na natureza quanto no interior das dependências da Casa da fazenda do Buriti Bom. Vale lembrar também, que se os encontros de Lalinha e iô Liodoro se dão em ambiente protegido, na calada da noite, o defloramento e a subsequente atividade erótica de Maria da Glória e nhô Gualberto se dão ao ar livre, no Alto Grande, "lugar escondido, bonito", que faz o contraponto com a Baixada onde se localiza o Brejão-do-Umbigo. No redemoinho dialético que é o texto rosiano, dentro e fora, alto e baixo, natureza e humano intercambiam seus valores e características de forma a ser quase impossível fixar uma paisagem e/ou situação que não se transforme no seu oposto.

No tocante à prostituição masculina a que o texto de Suetônio faz referência, tal prática não encontra menção em "Buriti". Há, no entanto, a atração de Lalinha em relação a Maria da Glória e mesmo o beijo furtivo entre elas, cujo sentido parece estar mais na intimidade erotizada das amigas. 
Da mesma forma, os encontros noturnos entre Lalinha e seu sogro, nos quais ela se vê como uma prostituta, demandando o pleno engajamento de iô Liodoro e investindo na "invenção" de "uma experimentada ciência lasciva" (B, 229), não deixam dúvidas quanto à ligação possível entre este pequeno significante - espíntrias - e o contexto maior da obra, seja pela prática referida em Suetônio ou pelo uso posterior como moedas nos bordéis.

Mas iô Liodoro se retardava, de propósito? - "Que é que você acha da moagem, minha filha?" - ele perguntou. Ríspida, ela retrucou: - "Nada. Nada. Nada." Por que tanta hesitação? Seria ele também um covarde? Não via que todo assunto que ali não soasse de ódio ou amor, de voluptuosidade ou violência, cruelmente a ofendia? Um homem!

Ferisse-a, batesse-lhe, gritasse infames acusações - mas violador, macho, brutesco. Como poderia chamar-lhe? "Prostituta"? E ela, desabrida - "Sim, sou uma, sim! Pois então?! Você me quer, me agarre, me use!..." (B, 231/232)

Neste trecho, o elemento vegetal participa, mais uma vez, da trama, mais especificamente do embate entre a violência do desejo de Lalinha e a postura - ainda atenuadora de iô Liodoro. Fora de contexto, considerando a intenção erótica do encontro, e de forma apenas sugerida, a cana-de-açúcar se insinua reforçando, por um lado, a possibilidade de doçura e deleite e por outro o interdito cultural - a moagem processo de transformação do elemento natural em produto a ser comercializado, remetendo à esfera do trabalho da roça.

Aqui, o encontro entre a árvore do sertão e a flor da cidade ainda é tenso, pois se dá às vésperas da carta que anuncia o nascimento do legítimo herdeiro de iô Liodoro. $\mathrm{O}$ "brinquedo" inventado por ambos e que animam as noites do Buriti Bom dá aqui sinais de desgaste. Mesmo assim, na tentativa de manter a distância, iô Liodoro ainda expõe a contraface do desejo, naquilo que sua fala tem de incestuoso: "Que é que você acha da moagem, minha filha?" (grifo nosso)

\section{7 - Para concluir}

O patriarca árvore/palmeira. A filha, fruto suculento. Outra filha, Behú, que floresce após a morte. A nora, flor enxertada. Analisar as figuras que põem em movimento o sonho narrativo que é "Buriti" significa, necessariamente, enxergar que se trata de um jardim animado que evoca o imemorial ciclo de fertilidade, nascimento e morte da natureza, estando o elemento humano inserido nesta linha natural. 
A atmosfera feérica reinante nesta novela deve ser entendida, simultaneamente, como um convite à reflexão sobre alguns dos usos e costumes ligados à sexualidade humana. Embora a referência aos interditos sexuais e outros produtos da cultura, como a noção de pecado, possam ser encontrados ao longo do texto, a umidade enflorescida que envolve o elemento humano parece entrar-lhe pelas narinas, sendo o erotismo parte essencial que compõe o sopro divino que anima o homem, barro tornado carne.

Para retomar a epígrafe que abre este capítulo, na qual Gunter Lorenz faz menção aos "homens que ainda não perceberam as consequências do pecado original, que ainda não derrubaram as pontes para o paraíso", pode-se ir além e arriscar dizer que há, para algumas das personagens de "Buriti", livre trânsito entre este paraíso mítico e a atualidade histórica do sertão, como no caso de Liodoro.

Lalinha e Maria da Glória, cada uma à sua maneira e de acordo com suas próprias demandas, buscam a realização de suas fantasias eróticas, não sem entrar no embate com a força das convenções sociais que regem sua condição de moça virgem, “de família” (Maria da Glória) ou de moça à espera da volta do marido (Lalinha). Enquanto isso, iô Liodoro, faz do seu desejo a Lei, não conhecendo limites para sua sede de satisfação sexual, enquanto "preserva a moral" (ao menos na perspectiva de nhô Gualberto) de suas filhas.

O mesmo "compadre", por sua vez, que tanto louva a severidade e a proteção de Liodoro em relação a sua família, não chega a desaprovar a necessidade ininterrupta do patriarca pelo "lazer de catre". Se Gualberto censura Maria da Glória por ginetear a esmo pela propriedade, acaba por ceder às ordens desta por satisfazê-la.

Em tudo isso, não deixa de haver angústia, dúvida, hesitação, como é patente em diversos momentos nos monólogos internos de Lalinha e mesmo em seus diálogos com Maria da Glória. Mas isso não parece suficiente para estancar a busca pela realização da iniciação sexual, para Glória, e da consumação do longo jogo erótico entre Lalinha e Liodoro.

Tal nível de liberalidade em relação ao sexo, seja em fantasia seja em ato, pode, de fato, parecer "lenda", pelo menos quando pensada na perspectiva feminina. Talvez por isto Rosa marque a distância desta propriedade, o Buriti Bom, "lugar retirado de rota" - longe da rota cotidiana - situando-o numa geografia fantástica, numa região entre o inusitado e as margens do rio Abaeté. Somente num lugar com esta marcação poderia se dar ocasião para uma literatura que insiste em certa naturalidade do prazer e 
seu desfrute. Não falta a Maria da Glória a coragem para vencer os interditos e ir ao encontro daquilo "que é preciso se aproveitar escondido", deixando de lado a moral tradicional, insistindo num tempo/espaço onde a noção de censura, limite ou freio são temporariamente postos de lado.

Em termos formais, para tornar isto tudo literariamente possível, o que se encontra em "Buriti" é a poetização da natureza, sua animização, nos moldes do pensamento de Vico. Rosa é hábil em disseminar por todo texto signos, elementos plenos de simbologia erótica ligados à natureza, de forma a construir um cenário que participa da ação, do qual emana o erotismo que, de forma quase contínua, atua sobre algumas das personagens.

Bem entendido, não se trata de afirmar que as personagens, como iô Liodoro, Lalinha ou Maria da Glória, em suas fantasias ou realizações eróticas, agem dessa ou daquela forma exclusivamente por força das influências do lugar. Antes, afirma-se, isto sim, que, uma vez inseridos neste lugar "retirado de rota", propício à lenda, a natureza participa, significativamente, na composição do erotismo de "Buriti", dando ensejo à manifestação do erotismo das personagens, em uníssono com a natureza. É lícito afirmar, portanto, que Rosa cria um ambiente no qual a eroticidade da natureza precede o humano, sendo este último devedor no tocante à "herança" recebida. À esta, por sua vez, o homem também projeta o seu sopro, no caso, a fantasia - atributo indispensável para se falar em erotismo humano. Afinal, é a imaginação que ativa o desejo entre os homens, desnaturalizando a sexualidade ao inseri-la na dinâmica propriamente erótica. ${ }^{9}$

De qualquer forma, ante a exuberância de todas as passagens que evocam o brejo, árvores, plantas e outros elementos naturais plenos de sensualidade e sugestão eróticas, observa-se que a linguagem rosiana age como um véu. $\mathrm{O}$ ato sexual em si encontra-se, na maior parte do texto, velado, sugerido, em múltiplas variações afeitas à botânica - por exemplo - nunca nomeado de forma explícita, mas sempre aludido indiretamente. O que se revela, dessa forma, é a habilidade de Rosa em aproximar, através da linguagem, a exuberância da natureza com as inumeráveis formas de expressão do erotismo humano. Sua expressividade se dá através da função fecundante da linguagem que assoma à própria Natureza o imaginário que perpassa a sexualidade humana, criando este universo "retirado de rota", afeito à lenda, que é "Buriti".

\footnotetext{
${ }^{9}$ A relação entre o erotismo e a fantasia será aprofundada no capítulo 4.
} 
Capítulo 2 - O corpo da noite: polifonia indígena. 


\section{CAPÍtULO 2}

\section{O corpo da noite: polifonia indígena.}

"É noite, e, à noite, a escândalos e incestos

É natural que o instinto humano aceda!"

Augusto dos Anjos

\section{Introdução}

A importância dos fenômenos e manifestações da Natureza na fatura literária de "Buriti" é inequívoca. No capítulo anterior, alguns destes fenômenos foram analisados, buscando evidenciar sentidos ainda pouco apreciados nesta narrativa.

A flora, a água, o brejo, mais do que ambiência ou pano de fundo sobre o qual se desenvolve o drama das personagens, foram entendidos como elementos que participam ativamente da narrativa, como personagens que, à sua maneira, interagem com as demais. Isto graças ao animismo articulado de forma única pelo estilo rosiano, no qual a emanação da natureza transmite a algumas personagens um recado ancestral, que ultrapassa as barreiras da cultura e se atualiza no texto de forma quase mágica.

Neste capítulo, dando continuidade a este enfoque interpretativo, encara-se a noite, elemento chave para o entendimento de "Buriti". Como já observara Adélia Bezerra de Meneses (2010, p. 119), desde o título do volume Noites do sertão até o chão do texto, o vocábulo noite, metonimicamente, evoca o amor, o encontro dos amantes. Ponto culminante desta associação é a passagem: "Era custoso aceitar que Dona-Dona algum dia tivesse acordado o desejo ou o amor de Nhô Gaspar, que os dois tivessem tido uma noite." (B, 105, grifo nosso).

Aqui se verá o quanto esta noite tem, ela mesma, para além do mero fenômeno natural, uma corporeidade feita de múltiplos elementos que só vêm a tornar ainda mais pertinente a sentença da estudiosa brasileira, na medida em que se vislumbrará nuances interpretativas que até o momento jaziam na escuridão da crítica de "Buriti". Dentre estes elementos, caberá destacar a lua, os sons e o mutum, pássaro noturno, mítico, referido nesta narrativa e que dá nome ao local onde o protagonista Miguel/Miguilim passou parte de sua infância. 


\section{1 - A noite: presente da Cobra Grande para os amantes.}

Os trechos abaixo destacados servirão de entrada e referência para a análise subsequente. Todos os grifos são nossos.

O certo, que todos ficavam escutando o corpo do noturno rumor, descobrindo os seres que o formam. Era uma necessidade. $O$ sertão é de noite. Com pouco, estava-se num centro, no meio de um mar todo. [...] dificuldade em separarem-se sons, de seu amontôo contínuo. (B, 84)

Lua defeita , o silêncio se afunda, afunda - o silêncio se mexe, se faz. [...] Depois, tanto silêncio no meio dos rumores, as coisas todas estão com medo. Então, o que vem, é uma cobra desconforme, cor de olhos. Calamidade de cobra. Um mau espírito, ainda sem nenhuma terra. $(\mathrm{B}, 115)$

A mata marginal se cerrava, uma enormidade, negra de virgem. [...] Aquelas árvores de beira-de-rio, [...] tomavam tamanhos fora do preceito, bojavam diâmetros estrusos. [...] Lá dentro, se enrolava o corpo da noite mais defendida e espessa. (B, 124/125) Quem tapa a noite é a madrugada. Os macaquinhos gritam, não é bem de frio - dançam ao redor de um trem nu. Cobra grande comeu um deles. Sucuri chega vem dentro de roça. Um macaco pulava num pé só, sacudia no ar uma perna tesa dura de frio, entanguida, ele assim parecia até um senhor. Mas, muito antes da luz das barras, os passarinhos percebem o sol: pio, pingo, pilgo, silgo, pinta-alecrim..." (B, 135/136)

Pode-se rastrear, a partir das citações acima, a presença de alguns elementos da lenda tupi da criação da noite, tal como relatada por Couto de Magalhães em seu volume $O$ selvagem, de 1876.

O caráter noturno da narrativa e a importância do elemento sonoro, resultado da intensa atividade de todos os habitantes da noite, são características inegáveis presentes nesta novela. Na trilha de Adélia Bezerra de Meneses, o vínculo entre noite e sexo ganha destaque como articulação central no texto e abre possibilidades de interpretação ainda mais significativas quando aproximadas deste e de outros mitos indígenas. Além disso, pode-se elencar a figura da cobra, sua inserção no meio aquático e sua aproximação com a noite, como se pode ver pelas passagens acima destacadas entre outras. 
A lenda em questão pode ser encontrada no volume Antologia de lendas do índio brasileiro, de Alberto da Costa e Silva, encontrado na biblioteca pessoal de Guimarães Rosa, disponível no IEB. Aqui ela será exposta em itálico.

Era um tempo no qual a noite não existia para os homens. Era sempre dia e os animais também não existiam. Os objetos inanimados conversavam com os índios. A noite era guardada pela Cobra Grande, no fundo do rio.

A filha da Cobra Grande decide sair de seu reino e se casar com um índio que tinha três servos. O índio dispensa os servos e chama a filha da Cobra Grande para se deitar com ele. Ela responde que não seria possível, porque ainda não era noite. $O$ índio se espanta e diz que a mulher falava de algo incompreensível, que não existia. A mulher responde que ele poderia mandar seus servos para o reino da Cobra Grande para que esta lhes desse a noite, que era guardada dentro de um coco de tucumã, no fundo do rio.

Dada a ordem, os três servos vão ao encontro da Cobra Grande. Esta lhes entregou um coco de tucumã fechado por uma resina e advertiu-os de que não o abrissem, caso contrário todas as coisas se perderiam. De dentro do coco ouvia-se um barulho, ten-ten-ten-xi..., que era o barulho dos sapos e grilos que cantam à noite.

Intrigado, um dos índios sugeriu que se abrisse o coco. Outro respondeu que não, ou estariam perdidos. Mais adiante, não resistindo à curiosidade relativa ao barulho que vinha do interior do coco, fizeram fogo na canoa e derreteram a resina que o mantinha fechado. Aberto o coco, imediatamente escureceu. O piloto da canoa disse: estamos perdidos, e a moça já sabe que abrimos o coco de tucumã.

A moça em sua casa disse: eles soltaram a noite, vamos esperar a manhã.

Então, todas as coisas espalhadas pelo bosque se transformaram em animais e pássaros. As coisas espalhadas pelo rio se transformaram em patos e peixes.

A filha da Cobra Grande ao ver a estrela d'alva disse ao marido: a madrugada vem rompendo, vou dividir o dia da noite. Enrolou um fio e disse: tu serás cujubim. Fez o cujubim com a cabeça pintada de branco e o corpo pintado de vermelho e disse-lhe: tu cantarás para todo o sempre quando a manhã vier raiando. Depois enrolou um fio, 
despejando cinza sobre ele e disse: tu serás inhambu, para cantar nos diversos tempos da noite e de madrugada.

Desde então os pássaros cantam nos diversos tempos, e de madrugada para alegrar o começo do dia.

Quando os três servos chegaram, o moço disse-lhes: Não fostes fiéis, soltastes a noite e todas as coisas se perderam, e vós também, que se transformaram em macacos, andareis para sempre pelos galhos dos paus. (CASCUDO, 2001, 209/211).

\subsection{1 - Paraíso perdido}

O próprio Couto de Magalhães comenta a semelhança desta história com o mito de origem do Gênesis. Ambas falam de um tempo onde havia plena harmonia e que, devido a uma desobediência, o antigo estado se transforma definitivamente, degradando-se, em certa medida, em relação à condição original.

O desejo, o fruto proibido oferecido pela serpente/Cobra Grande, a desobediência que se concretiza num misto de medo e curiosidade e a consequente mudança do modus vivendi, são alguns dos elementos estruturantes dos mitos em questão que aqui se observam.

O aparecimento da noite, na lenda indígena, tem, no entanto, a função de por em marcha o tempo, instituindo a rítmica alternância do dia com a noite, na medida em que põe uma quebra ao modo único da vida sob a luz do sol. Diferente, portanto, do Gênesis, no qual a divisão entre dia e noite aparece como obra do divino, que precede a criação do homem e o aparecimento da serpente.

A noite traz a escuridão povoada de barulhos, sendo, na versão de Rosa, o “corpo de noturno rumor", a própria carne disto que deixa de ser mero fenômeno astronômico para virar personagem. O "corpo da noite" se defende, tem espessura e se enrola, é a própria cobra. A desorientação e o perigo da convivência com seres que até então não existiam é a consequência da união do casal mítico, sendo clara a função fecundante que faz com que os objetos inanimados ganhem vida, fazendo aparecer os pássaros e outros animais de terra, água e ar. 
A Cobra Grande, na visão de Câmara Cascudo (1983, p. 128), "é um anel de um mito religioso". Monstro aquático da tradição amazonense, tem ação quase sempre destrutiva, malévola, cruel. "Cada igarapé, rio, lago tem sua Mãe e esta só aparece como uma imensa serpente. Não tem piedade nem aplaca a fome. Mata e devora quem encontra. Vira as barcas, arrasta os nadantes, estrangula os banhistas, apavora todos. A noite veem seus dois olhos de fogo, alumiando o escurão."

As referências às cobras em "Buriti" são diversas, chegando a serem insistentes:

O brejão era um oásis, impedida a entrada do homem, fazia vida. Não se enxergavam os jacarés, nem as grandes cobras, que se entranham $(\mathrm{B}, 108)$

A noite traspassa de longe, e se pertence mais com o chão que uma árvore, que uma barriga de cobra. Tem lugar onde é mais noite do que em outros. $(\mathrm{B}, 114)$

Atrás, em cada canto do campo, tem uma cobra, espreitante. O vento muda: traz voz, marmugem. (B, 115 - grifos meus em todas as citações)

Destaque-se ainda, no texto de Rosa, o seguinte trecho: "Então, o que vem, é uma cobra desconforme, cor de olhos. Calamidade de cobra. Um mau espírito, ainda sem nenhuma terra." (grifo nosso) Num trecho do Olavo Bilac, citado por Câmara Cascudo (Idem, p. 122), lemos: “[...] a Boi-guaçu mata todos os animais, mas não os come inteiramente: come somente os olhos da carniça; tantos olhos devora, que fica cheia de luz de todos esses olhos: o seu corpo transforma-se em ajuntadas pupilas rutilantes [...]"10 (grifo nosso).

Vale salientar, seguindo o pensamento do folclorista, que a "serpente ser o próprio rio, ou sua gênese $(\mathrm{C} i$ ) dispensa comentário para quem estuda folclore". Se a escrita de Rosa faz menção à origem mítica dos tempos, contrastando-a com a atualidade histórica suposta como o tempo presente da narrativa, qual seja, as condições da família e da sociedade sertaneja no Brasil pós-imperial, não é demais lembrar que os elementos naturais - alguns deles estudados no capítulo anterior - carregam, em si, esta ligação com a origem, que o ficcionista trabalha à sua maneira.

\footnotetext{
${ }^{10}$ Este trecho de Olavo Bilac pode ser encontrado, em espanhol, no livro El folclore en el Brasil, de Basílio Magalhães, encontrado na biblioteca particular de Guimarães Rosa, no IEB.
} 
Guimarães Rosa, ao evocar e trabalhar ao seu modo esta figura mitológica, expõe toda a ambivalência relativa tanto à noite quanto à sexualidade ${ }^{11}$. Por meio da Cobra Grande a noite entra no mundo dos homens, graças ao desejo sexual do moço em relação à filha do ente mítico. Perde-se a antiga estabilidade, estática, em troca de um ciclo onde se alternam dia e noite, criação e destruição, vida e morte.

Trata-se de colocar, de forma muito sucinta, a proposta de leitura do presente trabalho. "Buriti" traz à baila a discussão relativa a sexualidade humana trabalhada nesta encruzilhada: as possibilidades entre o uso civilizado, condicionado pelo fluir do tempo histórico, balizado por interditos e regras, e uma sexualidade anterior a esta condição, livre, sem freios, que faz menção a um tempo mítico.

Ao longo de toda a trama pode-se perceber, nas entrelinhas, a máxima riobaldiana que no mesmo ano de publicação de Corpo de baile se tornaria conhecida do público: "viver é muito perigoso". Em "Buriti”, naquilo que a novela tem de erótica, trata-se de pensar este fenômeno, o erotismo, de forma integral, considerando-o em toda sua plenitude, tomando suas características positivas e negativas, tanto no plano das personagens humanas quanto nos aspectos naturais, como a flora, a fauna e a geografia.

O sertão é de noite, feito para as "luas-de-méis", os encontros amorosos, consentidos ou não, para os arroubos impulsivos, para a violência do desejo que encontra sua via de expressão, para o encontro com forças que resistem ao entendimento e ao cálculo racional. Contraponto natural do dia, onde tudo se toma pelos afazeres da casa, da fazenda, dedicado aos trabalhos duros da roça, momento regido pela ética do trabalho, da acumulação, da construção do mundo civilizado.

\footnotetext{
${ }^{11} \mathrm{O}$ uso da mitologia indígena pelos autores da literatura brasileira é evidente, pelo menos desde o Romantismo. Aqui, ao fazer referência ao mito da Cobra Grande, não se pode deixar de mencionar o feito de Cobra Norato, de Raul Bopp, e sua versão muito particular do legado amazônico, bem afinado com a vertente primitivista da primeira geração do Modernismo nacional. Neste poema percebe-se, assim como no texto de Rosa, a natureza manifestando um erotismo próprio, participando ativamente da viagem do personagem em busca da filha da rainha Luzia. Um cotejo mais apurado entre os textos - "Buriti" e Cobra Norato - mereceria um trabalho à parte, inclusive como sendo uma das muitas fontes usadas pelo escritor mineiro para a composição de sua obra. Breve sugestão é comparar o nome dado por Rosa, "Brejo do Umbigo", posto lado a lado com o verso de Bopp: "A terra agora perde o fundo/Um charco de umbigo mole me engole", (BOPP, 1978, p. 10 - grifo meu)
} 
Aqui, como em outros momentos, Rosa trata de fenômenos humanos considerando-os em seu caráter integral. Há em cada ato do homem o bom e o mau, o construtivo e o destrutivo, o que, sem dúvida, causa angústia, uma vez que lança o sujeito num redemoinho dialético do qual é difícil extrair uma síntese definitiva e segura. Trata-se da lógica do "mundo misturado" de que fala o herói Riobaldo, tão bem analisada no trabalho de Davi Arrigucci Jr. (1994)

Mais do que fazer menção à lenda indígena, indicando pontos de correspondência entre sua fatura literária e a tradição oral, Rosa se aproveita da lenda para fazer a sua própria criação.

Em "Buriti", a noite, assim como a flora, ganham tratamento privilegiado, sendo possível considerá-los como personagens que, à sua maneira, participam da ação tanto quanto as personagens "humanas".

A noite não é apenas a ausência de luz, um acontecimento natural, uma ambiência ou pano de fundo para a ação. Ela tem corpo, semelhante ao de uma cobra que se enrola em si mesma, vive à espreita e se compõe de uma infinita sucessão de silêncios e rumores. Além disso, pode-se estabelecer uma relação de proximidade, de identificação sem precedentes entre a noite e o personagem mor da ficção rosiana, o sertão: “O sertão é de noite.” (B, 84)

Exemplos da exuberância sonora deste corpo não faltam. Alguns poucos trechos de "Buriti" bastam para que se entenda a importância da dimensão auditiva contida dentro deste recipiente narrativo, análogo ao coco da lenda indígena.

Miguel e o rapaz comeram seu farnel, já no sufusco e tempo fresco, já anoitecendo, enquanto ouviam o cucubo da coruja e o regougo da raposinha. Entrementes ocorria também o vozejo crocaz do socó: - Cró, cró, cró... - membranoso. [...]Não dilatava, bastando a gente guardar um pouco o silêncio, e o confuso dos sons rodeava, tomava conta. $(\mathrm{B}, 83)$

[...] (Miguel) reconheceu, remoto, o barulhinho do monjolo. De par em par, de minutos, o monjolo range. Gonzeia. Não se escuta sua pancada, que é fofa, no arroz. Ele estava batendo, todo o tempo; eu é que ainda não tinha podido notar. [...] O ranger do monjolo é como o de uma rede. [...] e o outro gemer? - "Esse outro, é de bicho do brejo..." - Glorinha disse. $(\mathrm{B}, 85)$ 
O que era próximo e um, era a treva falando nos campos. $(\mathrm{B}, 114)$

De desde que o sol se some, e os passarinhos do branco se arrumam em pios, despedidos, no cheio das árvores. Aí começa o grôo só, do macuco, e incoam os sapos, voz afundada. Com as corujas, que surgem das grotas. $\mathrm{O}$ clique-clique de um ouriço, no pomar. O nhambú, seu borborinho. O ururar do uru, o parar do ar, um tossir de rês, um fanhol de porteira. (B, 114/115)

Exemplos como os acima destacados são abundantes ao longo do texto, e poderiam ser expostos à exaustão. Abre-se a oportunidade, nestes trechos, para Rosa desfilar toda sua erudição e criatividade, que vai desde a mais simples onomatopeia ("o grôo/ "Cró, cró, cró”") às inventadas poeticamente (“o ururar do uru, o parar do ar”) nas quais se imiscuem verbos pouco usados, como os sapos que "incoam"/começam sua particular cantoria de "voz afundada".

Com tantas passagens remetendo aos sons que fazem da noite o que ela é, disseminados ao longo do texto, parece fácil construir a ponte entre o texto de Rosa e a lenda apresentada. Percebe-se também a distância entre elas, uma vez que a noite composta por Rosa não é feita apenas pelo mar de ruídos naturais - grilos, sapos e aves - pois não se trata do tempo mítico do aparecimento da noite para os índios.

A noite do "Buriti" mostra a mistura dos rumores da natureza com ambientação já civilizada, até certo ponto, com o "fanhol de porteira", o "tossir de rês", assim como o rangido intermitente do monjolo e mesmo os índices da atividade erótica do patriarca da família, barulho constante no Buriti Bom, que Maria da Glória e Behú prefeririam não ouvir:

(Lalinha) Ouviu galos, continuavam os grilos. E assim o silêncio da casa do Buriti Bom - que era como levantada na folha de uma enorme água calma. [...] e ouvia. Ouviu. Era um rumor de cavaleiro chegando, estacara encostado nos pilares da varanda. [...] Mas era iô Liodoro, retornando. Iria escutar-lhe os passos, quando viesse pelo corredor. [...] iô Liodoro, infatigável no viver, voltando do amor de cada dia, como de um trabalho rude e bom. $(164 / 165)$

De qualquer forma, ante a treva que desorienta pela cegueira, é "uma necessidade" estabelecer um parâmetro de orientação, desta vez pela audição, a fim de garantir a sobrevivência. 
O certo, que todos ficavam escutando o corpo do noturno rumor, descobrindo os seres que o formam. Era uma necessidade. O sertão é de noite. Com pouco, estava-se num centro, no meio de um mar todo. [...] dificuldade em separarem-se sons, de seu amontôo contínuo. (B, 84)

No caso dos homens, vê-se logo a desvantagem em relação aos animais. Para fazer a travessia da escuridão, portanto, somente fazendo uso deste recurso "primitivo", mais do animal que do humano, a fim de se separarem os sons de seu "amontôo contínuo". Sendo a noite também sinônimo de sexo, será preciso coragem para assumir o risco de se perder no encontro, naquilo "que a noite traz." (B, 91)

\section{2 - O noturno rumor}

As observações feitas até aqui estabelecem, portanto, um ponto de comunicação entre o texto rosiano em questão e alguns elementos da mitologia dos índios do Brasil. Na correspondência de Rosa com seu tradutor italiano encontra-se a menção a figuras relevantes da mitologia indígena, como a Anhanga - "o diabo dos índios tupis e guaranis", ou a tagoaíba, "fantasma, aparição sobrenatural, assombração" (ROSA, 2003, p. 85 e 113.).

Investigar a presença de alguns elementos deste arcabouço mitológico no texto de "Buriti" mostra-se produtivo em termos críticos, a partir, por exemplo, das indicações do próprio Rosa. Na apresentação do personagem vegetal - Buriti Grande o autor, não por acaso, através da lucidez lunática do "bobo risonho" Chefe Zequiel, nomeia a planta de "Palmeira do Curupira", $(\mathrm{B}, 126)$

Com esta denominação, é possível identificar, do ponto de vista crítico, verdadeira encruzilhada entre a erotização da natureza tratada no capítulo precedente e o universo indígena como fonte de significações eróticas próprias. Isto porque o Curupira, segundo João Barbosa Rodrigues (1890, p. 4) em seu Poranduba amazonense, tem o hábito de bater nas árvores para ver se estão firmes usando seu pênis "que é de tamanho extraordinário" ${ }^{12}$. Não bastasse isto, lê-se, na sequência da apresentação desta palmeira, via narrador, que a natureza é, por excelência, o cenário primeiro para a prática erótica,

\footnotetext{
${ }^{12}$ Dentre o material do arquivo pessoal de Guimarães Rosa disponível no IEB, o caderno 14 traz uma menção ao volume de Barbosa Rodrigues aqui citado.
} 
no encontro entre seres mitológicos e a humanidade ainda jovem, ardente: "Como o Curupira, que brande a mêntula desconforme, submetendo as ardentes jovens, na cama das folhagens, debaixo do luar." (B, 126 - grifos nossos)

De forma análoga à análise feita dos elementos da Natureza no capítulo anterior, é notório aqui a relação dos elementos afeitos à noite, a saber, a escuridão, a lua, os barulhos e mesmo o mutum (ave de hábitos noturnos), e sua relação com o erotismo que perpassa a obra. Assim, de forma nem sempre explícita, a menção a estes elementos ativa relações de significado que contribuem para reforçar o sentido erótico da narrativa.

O vínculo estabelecido entre a noite, os sons que a compõem e o sexo desdobrase entre os elementos que são adjacentes ao significante "noite". A mitologia indígena, tendo o mito da Cobra Grande como primeiro índice explícito, fornecerá os pontos de articulação de sentido que restam ser assinalados para a compreensão da interpretação aqui proposta.

Cabe lembrar que a mitologia grega em Guimarães Rosa já foi bastante percorrida, como nos trabalhos de Luiz Roncari (Buriti do Brasil e da Grécia, O Brasil de Rosa ou $O$ cão do sertão) e Helóísa Vilhena de Araújo ( a raiz da alma) enquanto que a relevância dos mitos indígenas, ao menos no tocante a Corpo de baile, ainda demanda pesquisa mais aprofundada.

É relevante citar, ainda, que o interesse de Rosa pela cultura indígena pode ser encontrado no levantamento feito por Suzi Sperber em seu Caos e cosmo. Sumariamente, cabe citar aqui alguns títulos como Antologia de lendas do índio brasileiro, de Alberto da Costa e Silva, Viagem ao Araguaia, do já mencionado Couto de Magalhães, além de outros volumes que tratam de relatos de viagens e explorações de todo o território nacional, como, por exemplo O naturalista no Rio Amazonas, de Henry W. Bates.

Outros mitos indígenas, além do recolhido por Couto de Magalhães, dão conta da associação da noite com os barulhos que lhe dão corpo e com o elemento erótico. $\mathrm{O}$ fenômeno natural, astronômico, parece verdadeiramente indissociável de todas as suas decorrências para a terra e seus habitantes. Numa pesquisa sumária, pode-se encontrar 
outras histórias, também dos índios brasileiros, nas quais é possível identificar este mesmo vínculo.

Antes, porém, desta investida, desde já se faz a ressalva de que junto com este canto noturno que associa sexo/noite/sons é necessário vislumbrar que, em "Buriti", apresenta-se, desde logo, uma noite terrível, que pode também trazer o medo, a violência e a destruição. Esta é a perspectiva do Chefe Zequiel, sem a qual a apreciação do "noturno rumor" ficaria incompleta.

\subsection{1 - Intermezzo: Para além dos confins do ouvir.}

"Nhossim, escutei o barulho sozinho dos parados..." (B, 129)

A lenda da origem da noite exposta acima traz uma advertência. Ao oferecer aos índios a noite dentro do coco fechado, a Cobra Grande adverte para que este não fosse aberto, ou tudo se perderia. Os objetos inanimados que até então conversavam com os homens tornam-se animais o que, em muitos casos, pode representar uma ameaça. Ao lançar as trevas sobre a terra, ocasião para o amor, sem dúvida, apresenta-se algo a mais, da ordem do terrível, daquilo que escapa ao controle e à possibilidade de compreensão. Vale mencionar o caráter homólogo deste mito em relação ao de Pandora, que abre a caixa proibida fazendo sair dali os males que passarão a assolar o gênero humano.

Chefe Zequiel, como outros tantos "bobos" na obra de Rosa, tem uma sensibilidade extraordinária que, em "Buriti", se expressa na extrema capacidade de captar e transmitir aos demais tudo aquilo que sai do coco de tucumã/caixa de Pandora. O excêntrico Zequiel, assim como Gorgulho de "Recado do morro", escuta "o que para ouvido de gente não é $[\ldots . .]^{, 13}(\mathrm{~B}, 106)$

Diga-se mais uma vez que Zequiel, assim como Malaquias - verdadeiro nome do Gorgulho - fazem referência aos profetas hebreus. Profetas, segundo o dicionário Michaelis, são "anunciadores ou intérpretes de uma mensagem divina". Malaquias pode

\footnotetext{
${ }^{13}$ Esta aproximação entre Gorgulho e Zequiel devo ao professor José Miguel Wisnik, em aula ministrada no Atelier Paulista, em abril de 2015, registrada em áudio no endereço http://www.atelierpaulista.com/index.php/peter2011-2/3667-2
} 
ser traduzido como "meu anjo" ou "meu mensageiro", sendo que os anjos também eram considerados mensageiros de Deus.

Ezequiel, por sua vez, pode ser vertido por "Deus fortalecerá" ou "será fortalecido por Deus". ${ }^{14}$ Chefe Zequiel é descrito como alguém que "por erro de ser" se destaca por sua incomum capacidade de ouvir e decifrar os segredos da noite, o que o torna quase totalmente improdutivo na rotina do Buriti Bom. Tomado por sua missão, adoece a ponto de quase morrer, "Como se o poder da noite de propósito pesasse sobre aquele enjeito de criatura, que queria sair de seu errado desenho, chegar a gente, e o miolo da noite não consentia, para trás o empurrava.” (B, 208) A promessa de fortalecimento inscrita em seu nome só vem ao final da narrativa, quando, após a morte de Maria Behú, ele se percebe curado.

Estes "profetas" lunáticos do sertão rosiano, têm suas peculiaridades se comparados aos bíblicos. Aquele que transmite, originalmente, a mensagem não é, claramente, uma instância divina. Sabe-se, no entanto, que este "emissor", situado além ou alhures, tem algo a dizer e precisa de alguém que carregue este recado. O Morro da Garça, assim como "a treva falando nos campos", têm ao menos um fundo em comum na sua mensagem, a saber, a morte, a violência.

O texto de Rosa, ao abordar a perspectiva do Chefe Zequiel e seu "estudo terrível" (B, 91), além de por o leitor (ouvinte?) em contato com uma miríade de sons indistintos e onomatopeias, expõe o lado mortífero da noite. Fosse um paciente psiquiátrico, facilmente poderia ser diagnosticado como portador de um transtorno paranoide, dada a espera iminente de um ser que vem para assassiná-lo, a Morma, "mulher que pariu uma coruja" $(\mathrm{B}, 141)$, sem mencionar a referência a todos os seres disformes e/ou de formas e ações no mínimo grotescas, impensáveis ou impensadas, que chegam a lembrar um quadro de Hyeronymus Bosch: "É uma pessoa aleijada, que estão fazendo. Dou medida de três tantos! Só o sururo... Chuagem, o cru, a renho... forma bichos que não existem. De usos, - as criaturas estão fazendo corujas. Dessôro, caras mortas. [...] No que é que, bichos de todos malignos formatos" (B, 142, grifos meus)

\footnotetext{
${ }^{14}$ Sobre a etimologia e significado dos nomes hebraicos, sou grato ao amigo e rabino da Congregação Israelita Mineira, Uri Lam.
} 
Como se trata de uma personagem literária, no caso de suma importância para a compreensão da narrativa, é indispensável destacar sua função de nomear e traduzir o "amontôo contínuo" da noite, sendo Zequiel um "mestre da linguagem", como quer Luiz Costa Lima (1974, p. 161), ou ainda sua condição de "sentinela", termo usado diversas vezes em "Buriti" e bem salientado na tese de doutorado de Erich Nogueira (2014, p. 115), o que só reforça, entre outros fatores, a aproximação do personagem rosiano com o profeta bíblico.

Em meio a este "estudo terrível”, no qual o iletrado, à exaustão, lê e interpreta o livro da natureza, na medida em que escuta seus sinais e os traduz tanto quanto possível em palavra, a violência surge inequívoca.

No adoecimento de Zequiel, concomitante ao de Maria Behú, o Chefe passa a negar o relato do "descomposto das visões que seus ouvidos enxergavam" (B, 208). Mesmo assim, como num momento em que seu temor se recrudesce e a violência se volta toda contra ele, o lunático teme "umas mãos", "roxas mãos, que por estrangulação rodeavam." (B, 208).

Em trecho no qual se aproxima do "miolo maior" (B, 141) da noite, verdadeira "sinfonia da noite no mato", para usar a expressão de Edoardo Bizarri (ROSA, 2003, p. 97), destaca-se no trecho o ataque certeiro de uma coruja a uma presa, conforme explica o próprio Rosa ao seu tradutor italiano (Idem, p. 105/106).

Sem desprezar a riqueza das paisagens sonoras captadas por Zequiel, que abrem inúmeras possibilidades interpretativas, ressalta-se aqui a presença de um perigo eminente, de um ato de ferocidade, tanto de ordem natural quanto humana.

É o que aparece numa destas sequências, quando no rastro dos sons indistintos a narrativa recai sobre a tocaia e morte de um casal de tamanduás. A passagem em questão, de quase três páginas, traz um anúncio, quase como um quadro pintado dentro de outro maior: "Daí, depois muito silêncio, tem um pássaro que acorda. Mutum. O mutum se acusa, o mutum, crasso. As pessoas mais velhas conversavam, do que havia entre o mato e o campo" (B, 115/116) 
A referência ao mutum permite estabelecer uma ligação com a história de Miguilim/Miguel, encenada no Mutum. E não por acaso, alternam-se as referências entre os adultos em contraposição às crianças, além de referências mais ou menos explícitas a "Campo geral":

As pessoas mais velhas conversavam, do que havia entre o mato e o campo $(\mathrm{B}, 116)$

O mato do Mutum é um enorme mundo preto, que nasce dos buracões e sobe a serra.

As pessoas mais velhas são inimigas dos meninos. Soltam e estumam cachorros, para irem matar os bichinhos assustados - o tatu que se agarra no chão dando guinchos suplicantes [...] e os cachorros estão rasgando o sangue dele, e ele pega a sororocar.

O tamanduá. [...] No esgueirar as compridas cabeças, para escapar, eles semelhavam tontos, pedintes, sem mossa de malícia, como fossem receber comida à mão. Era de por piedade. Os homens mataram, com foiçadas e tiros, raivavam.

O excurso em torno do personagem Miguel/Miguilim e "Campo geral" se torna necessário, aqui como em outros momentos desta tese, para depois retomarmos o "miolo" central deste capítulo.

A cena dos tatus perseguidos e mortos já havia sido mencionada anteriormente, de forma breve, na recordação do primeiro serão de Miguel no Buriti Bom, sendo clara a evocação da infância do protagonista ${ }^{15}$ e a impregnação do trecho com o tema da raiva e da violência desmedidas dos homens contra os animais indefesos.

Curioso notar ainda o curso da narrativa, como se da paisagem sonora de Zequiel houvesse ocasião para a evocação de um território alheio, afeito à Miguel e suas vivências dolorosas, numa aparente fusão entre o que o Chefe escuta e o que Miguel relembra. Cumpre assinalar que a rememoração do protagonista, quando de seu retorno ao Buriti Bom, é disparada justamente às barras do anoitecer, facilitada pelo "confuso de sons" que o rodeiam, sobretudo o "sipipilo do regato" e os grilos, "sempre surgindo". (B, 84/85)

\footnotetext{
${ }^{15}$ O horror de Miguel pelas caçadas, expresso em "Buriti" na página 88, relaciona-se com mais de um trecho de "Campo geral", onde se registram a fúria dos caçadores no matar animais, coelhos e tatus, e a torcida, via identificação com a vítima, de Miguilim para que os animais se salvassem.
} 
Qual um motivo musical que, num crescendo, se repete, o trecho da escuta de Zequiel se dá entre a segunda viagem do rapaz ao Buriti Bom e um novo flash back da primeira visita, na companhia de Gualberto. Aproveitando a noturna "submúsica" que invade o pavilhão auditivo do Chefe e o contexto da rememoração de Miguel, o passado deste se mistura ao aqui e agora do "bobo", afinando-se as experiências que vibram no mesmo diapasão: o da violência que constitui a matéria vivida de um e outro e que jaz, latente, nas Noites do sertão.

É com esta tônica, noturna, soturna, trágica, grave, que Miguel se apresenta diante das moças do Buriti Bom. Entremeado ao escrutar terrível de Zequiel, o passado do arcanjo salvador mostra seu peso, a fundamentar a observação feita pouco antes sobre o "medo de repetição", motivo musical para o qual, talvez, se quisesse tapar os ouvidos. Esta marca, como será analisada mais detalhadamente adiante, se impõe, ou mesmo sobrepõe-se à possível leitura que associa a noite e seus rumores com a possibilidade do encontro amoroso. No caso de Miguel, é tímida sua contribuição para o erotismo que tomará volume na segunda parte de Buriti, e aqui está parte da explicação.

O mutum guarda para si uma participação no noturno encontro amoroso, à sua maneira, num tom certamente abaixo, como um ruído grave e surdo, fazendo vibrar os иu guturais do seu nome. Distinto, portanto, dos demais elementos naturais que enfeixam a trama de "Buriti”, de caráter mais expansivo e solar, estudados no capítulo precedente.

\section{3 - O rumor do mutum}

Para retomar a proposta deste capítulo, a seguir se apresenta mais um exemplo da união entre a noite e sua constituição, a um só tempo erótica e ruidosa. Recolhido no volume Vozes da origem por Betty Mindlin (2007, p. 85/87) a partir da narração de Dikboba Suruí, com o povo Suruí-Paiter, de Rondônia, mostra-se a noite sendo conduzida dentro de uma flauta. Abaixo a lenda, de forma resumida, em itálico.

Palop e Palop Leregu são irmãos. Palop Leregu saiu de sua aldeia para viver com o povo Mambetorei, ficando ali por um tempo. Palop saiu em busca do irmão, pois estava com saudade. No caminho, ouviu o irmão voltando, tocando uma flauta para anunciar sua volta. 
Após saudarem-se, Palop notou que o irmão trazia uma grande flauta de taquara, bem fechada com uma tampa de espiga. Perguntou o que era. Palop Leregu diz:

- Não é nada, não, coisas à toa, que estou carregando para alguém lá em casa, e não quero mostrar para ninguém!

Palop, no entanto, estava muito curioso, ouvindo barulhos misteriosos dentro da flauta. Leregu insistia que só poderia mostrar quando chegasse em casa.

Seguiram andando e, num momento de distração do irmão, Palop destampou a flauta. Imediatamente escureceu. Era a noite dentro da flauta, que até então não existia. Junto com a noite, saíram da flauta todos os tipos de plumas de pássaros e ouviram-se os barulhos da noite, ruídos e silvos.

Leregu ralhou com o irmão, reprovando sua atitude, insistindo que só deveria abrir a flauta quando chegassem em casa, e não no meio do caminho. Na mesma hora ele inventou pernilongos e outros mosquitos que atacam as pessoas no mato, quando escurece. Em resposta, Palop inventou micuins para o irmão se coçar bastante.

Os irmãos continuavam brigando, até que Palop pediu ao irmão para que desse um jeito de acabar com a escuridão.

Leregu atirou penas de nambu para o ar, como se fossem flechas, e viraram nambus, sentados nas árvores, assobiando. Estes pássaros são os primeiros a piar na madrugada. Fez o mesmo com as penas do nambuzinho e do cujubim. Depois voaram as penas do jacu, do mutum, de todos os pássaros que costumam aparecer de madrugada, virando aves verdadeiras. Logo começou a clarear.

Os irmãos alegraram-se, mas continuaram discutindo. Palop queixava-se do irmão ter inventado a noite, dizendo que seus filhos ficariam no escuro e poderiam machucar-se. Leregu retrucava dizendo que fora o irmão a soltar a noite. Palop propôs continuarem andando, acrescentando que, depois, daria cabo dessa invenção.

Chegaram à maloca, onde ficara a mulher de Palop. Lá ainda não escurecera. Palop quis ver o resto da noite dentro da taquara. 
Palop Leregu recomendou: “abra de uma vez!”

Palop destapou a flauta e escureceu de uma vez. Só que agora, como sobrara pouca noite na taquara, passou a haver dia e noite.

Tanto nesta lenda como na relatada por Couto de Magalhães, observa-se o mesmo rumor que atiça a curiosidade dos personagens no caminho de uma viagem de volta ao lugar de origem. Note-se, para não perder a relação com "Buriti”, que Miguel empreende esta viagem de volta, uma vez que volta ao sertão de origem, e é o ruído do "riinho" e da noite que se aproxima que disparam sua rememoração da primeira visita ao Buriti Bom. E, mais uma vez, prevalece o impulso transgressivo, ou seja, o que a noite contém está na ordem do proibido que deve ser devassado pelo sujeito diante da lei. Já se sabe: essa lei em "Buriti” será suspensa e contornada, instaurando um universo de outros possíveis para o desejo.

Nas duas lendas, a mesma curiosidade atiçada, seja no interior do coco de tucumã, seja no interior de uma flauta. Mas, de que servirá uma flauta tampada? É preciso abri-la e deixar sua música sair.

Se o elemento erótico é mais explícito na lenda registrada por Couto de Magalhães, aqui há apenas sugestão. Leregu parece desfazer da importância de sua carga, dizendo não ser nada, fingindo levar "umas coisas" para "alguém lá em casa", e insiste que seja aberto apenas lá, e não no meio do caminho, provavelmente já sabendo a finalidade daquela "invenção", para o bem e para o mal.

Do meio da noite, surgem os pássaros por ação do índio, assim como a filha da Cobra Grande que lhes dá sua forma e cor. E, graças aos pássaros, seus cantos e pios, anuncia-se a aurora.

No interior da flauta, ouvem-se os pássaros que cantam na noite, entre estes, não se pode deixar de notar, o mutum. Portanto, ao fazer a separação de um destes cantores da noite do "amontôo contínuo" dos barulhos, da total indiferenciação, destaca-se o mutum. Aplica-se aqui, para a interpretação do texto, por pura "necessidade", a indicação do narrador àqueles que se aproximam da noite do "Buriti": "O certo, que todos ficavam escutando o corpo do noturno rumor, descobrindo os seres que oformam. 
Era uma necessidade." (B, 84, grifo meu) Ou seja, trata-se de apurar os instrumentos para a análise do texto, e das configurações de seus seres, da mesma forma que se apura os ouvidos ante a noite escura. ${ }^{16}$

A presença desta ave, o mutum, constituinte desta noturna fauna mítica, mostrase significativa para o entendimento da perspectiva de Miguel no contexto maior de "Buriti". Mais surpreendente, no entanto, é a reiterada presença desta ave e sua simbologia noturna - e sexual - também na mitologia indígena. Acrescente-se, ainda, que como palíndromo, "mutum" permite fazer dois caminhos espelhados: de ida e de volta, sendo a ave de ligação entre Miguilim criança e Miguel adulto.

Outro mito, recolhido dentre os Ianomâmis por Bruce Albert (1990, 172/174. tradução minha) a partir da narração de Ikahi, dá conta da mesma conjunção noturna, na qual se mesclam o sexo, os cantos dos pássaros e o mutum. Aqui, a preocupação com a luz do dia e a importância da escuridão da noite são explícitas.

O povo macaco branco era "obrigado a copular em plena luz do dia". Isto porque os espíritos da noite, titikike, ainda não haviam sido mortos. Eles faziam fogueiras com a intenção de criar fumaça, que pudessem escondê-los em seus encontros amorosos. Até o dia em que se cansaram: eles queriam a noite, estavam cansados de transar na floresta à luz do dia.

Foi o Jaguar quem viu os espíritos da noite quando caçava. Ele ouviu os espíritos que estavam empoleirados a certa distância e sua música era audível. Cantavam e, ao mesmo tempo, davam nome aos rios da floresta: "Bei ya shiii! Bei ya shiii! Bei ya shiii!”. Sua lamentações e os nomes dos rios podiam ser ouvidos acima do canto triste dos mutuns que estavam empoleirados abaixo deles: “Hmmmm! Hmmmm! Hmmmm!”

Jaguar começou a atirar em todos os mutuns e outros pássaros que estavam próximos aos espíritos da noite. Ele atirou uma flecha que foi por entre folhas e galhos

\footnotetext{
${ }^{16}$ Em tese de doutorado recém defendida, Erich Soares Nogueira (2014), ao abordar a questão sonora de "Buriti", embora em perspectiva diversa da nossa, chama a atenção para a "pura voz da natureza", esforço máximo de condensação linguística por parte de Rosa, "amontoo contínuo" que dispara no sujeito o esforço para a busca de possíveis significações.
} 
e arranhou os espíritos. Surpresos, eles bateram suas asas enquanto chamava: "Shii tititititi!" Imediatamente anoiteceu debaixo da árvore e Jaguar adormeceu por alguns instantes, mas logo amanheceu.

Ele voltou à sua aldeia e perguntou à sua mãe se ela havia adormecido, ao que ela confirmou. Pensou: "É isso! Aqueles devem ser os espíritos que fazem a noite cair!" Decidido a atirar nos espíritos para fazer uma noite de verdade, ele pediu à mãe que fizesse uma fogueira enquanto ele estivesse fora, e ela fez perto da casa deles.

Novamente ele ouviu o canto que incessantemente nomeava os rios, num lamento sem fim. “Hmmmmm! Hmmmm! Hmmmm!” Jaguar imaginou se não seriam os mesmos espíritos da primeira vez que estavam empoleirados mais adiante. Ele tentou fazê-los sair, mas tinha dificuldade em vê-los, pois eram os espíritos da noite. Onde os espíritos estavam, havia uma mancha negra, uma mancha de noite. Jaguar fixou os olhos na direção deles enquanto estas começavam a se mexer e cantar novamente. Ele atirou nos espíritos, que foram ao chão. Jaguar adormeceu ao mesmo tempo em que a noite caiu, e acordou um tempo depois.

De volta a aldeia ele se deitou na rede, perto da qual sua mãe preparara a fogueira, a noite caíra e ele adormeceu. Seu povo, então, muito feliz, aproveitou a oportunidade para copular no escuro. A noite era muito curta e a aurora chegou logo. Eles disseram uns para os outros: “nós queremos mais noite!” a noite caiu novamente e o povo começou a pensar direito: "Sim, eram eles de verdade, eles realmente eram os espíritos da noite!”

Foi assim que aconteceu, há muito tempo atrás. Desde então, os espíritos permaneceram em forma espectral. Depois de Jaguar atirar neles, eles se espalharam em todas as direções. No começo, logo após terem sido atingidos, a noite era muito curta e a aurora logo chegava. Mas os espíritos da noite permaneceram e cresceram, $e$ agora conseguimos dormir mais. Os espíritos tinham se escondido entre mutuns, jacus e outros pássaros sobrenaturais que acompanhavam os espíritos da noite. Apenas depois de matar todos estes pássaros foi que Jaguar finalmente conseguiu atirar nos espíritos. 
Esta lenda não deixa dúvidas quanto à finalidade da noite, ou pelo menos aquela que se apresenta como possibilidade de desfrutar a sexualidade de forma diferente da conhecida até então. A noite e sua constituição ruidosa, fenômeno inédito nas três histórias indígenas aqui apresentadas, vale como uma descoberta. Instaura-se um novo tempo, dividido entre luz e trevas, cabendo à noite o tempo privilegiado ao encontro amoroso. "Lua-de-mel, luas-de-méis", diria a avó de Maria da Glória.

$\mathrm{Na}$ imbricada tessitura das narrativas rosianas, entre as novelas Corpo de baile por exemplo, ainda há ocasião para pensar a questão dos ruídos de forma transversal, como uma rede sonora que transcende o contexto de uma narrativa em específico. Isto porque parece possível - e mesmo inevitável - estabelecer uma associação desta massa sonora aqui apreciada com o caso de Maria Mutema, em Grande sertão: veredas. $\mathrm{O}$ nome - significante - criado por Rosa, a partir de "fonema", apresenta sua contra face lógica - o mutismo/“mutema" - e mortal.

Na história de Mutema, o chumbo derretido, disforme, que entra pelo ouvido do marido inconsciente pode ser aproximado com o amontoo sonoro, também disforme, que povoa a noite do Buriti Bom atingindo a todos indistintamente. Já as palavras de sentido mortífero proferidas por Mutema - chumbo tornado símbolo - remetem uma vez mais ao Chefe Zequiel - que do amontoo indistinto de ruídos faz emergir um discurso. A ação de Mutema, determinada a realizar o mal, refina seu arsenal (do chumbo à palavra), quiçá em função de suas vítimas, mantendo a entrada do duto auditivo como o caminho para a morte. Zequiel oferece seu duto auditivo em particular para, na condição de sentinela do Buriti Bom, fazer do mal que o cerca algo traduzível ainda que incompreensível - chamando para si os "segredos da noite".

Da mesma forma, pode-se pensar, no nível da estrutura mesma do romance rosiano, a existência deste conto paradigmático incrustado na trama do livro, ressoando quase como o chumbo solidificado - o conto - dentro do romance - o crânio do marido morto. "Buriti" apresenta algo semelhante na história de Do-Nhã. Esta personagem, mulher de "vida estúrdia", conta sua história aos ouvintes do Buriti Bom e faz menção a uma ética erótica bastante dissonante em relação aos costumes sociais mais conservadores, sobretudo quando esclarece ter vivido certo período de sua vida amasiada, de forma relativamente harmônica, com quatro homens ao mesmo tempo. 
O princípio elaborado por Walnice Galvão mostra-se certeiro também em relação à narrativa estudada aqui. Ela escreve (1986, p. 121): “A imagem da coisa dentro da outra, visualmente tão impressiva e tão rica do significado global do romance [...] reitera-se em suas páginas, em diversas variantes".

De forma análoga à Maria Mutema, Do-Nhã funciona como uma espécie de espelho no qual as personagens, principalmente Glória e Lalinha, podem mirar-se, vendo na feiticeira a força de uma mulher que assume seus desejos e leva-os a consequências inesperadas. Ao analisar a importância de Mutema e sua história para a fatura literária de Grande sertão: veredas, Cleusa Passos (2000, 141/142) salienta que esta "condensa desejos interditos e transgressores, revelando também aguda representação de uma busca [...]”. Vale a citação do estudo desta autora, pertinente aqui para pensar a presença da história de Do-Nhã em "Buriti:

O caso atua tal qual o espelho que ao receber a imagem a inverte, sugerindo sua totalidade, mas a tornando exterior e inquietante, sobretudo porque os desejos proibidos de Mutema se aproximam das personagens principais do livro, com a diferença de se concretizarem, apesar de penas e censura (PASSOS, 2000, p. 142).

Não resta dúvida de que a "busca" encenada em "Buriti" passa pela realização amorosa, o que faz ressoar os desejos de Lalinha e Maria da Glória. Neste espelho - ou caixa de ressonância - que é a história contada por Do-Nhã, vê-se a possibilidade de se afirmar, via certa dose de transgressão, a possibilidade de realização dos desejos que, de outra forma, permaneceriam calados, submetidos à lógica do interdito.

Em “Buriti”, além da narrativa de Do-Nhã, análoga ao conto de Maria Mutema, pode-se pensar, em paralelo, nos barulhos que constituem o corpo da noite, assim como o interior do coco - na lenda colhida por Couto de Magalhães. Nunca é demais lembrar que esta lenda, afinal, relaciona-se com o desejo transgressor do casal mítico de ter para si um tempo/espaço para a união amorosa: a noite, feita essencialmente de trevas e uma infinidade de sons indistintos.

Estes barulhos indiferenciados que compõem a noite, e entram de forma involuntária pela orelha das personagens, assim como o chumbo no marido inconsciente de Mutema, compõem o todo disforme que ronda os moradores do Buriti Bom e desafia 
o leitor de "Buriti". Cabe aqui o esforço por discriminar e analisar, ainda que um único destes elementos, para lançar alguma luz na escuridão ruidosa desta novela. À guisa de interpretação, selecionamos aqui o mutum, elemento comum nos mitos transcritos por Betty Mindlin e Bruce Albert, e indispensável para o entendimento do papel desempenhado por Miguel, tanto em "Buriti" quanto em "Campo geral", na sua meninice.

No tocante ao mutum, de acordo com as narrativas indígenas aqui apresentadas, sua associação com as trevas precede a descoberta humana da noite. Seja na condição de habitante da flauta junto com os outros pássaros, ou como pássaro mítico guardião do espírito da noite, o negror de suas penas testemunha a origem da noite em tempos imemoriais.

Mutum: inconfundível em seu canto gutural, representante noturno aproximado, na lenda, com o próprio espírito da noite que guarda para si as trevas. Indispensável para se compreender a perspectiva de Miguel dentro da narrativa, a importância deste elemento dentro da economia literária de "Buriti" e mesmo de "Campo geral" parece ainda pouco apreciada.

\section{4 - Mutum, solista.}

Miguilim, natural do Pau-Roxo, passa parte de sua infância no Mutum, local onde se desenrola "Campo geral". O protagonista sofre, em sua perspectiva infantil, alguns dos efeitos - trágicos - das viravoltas eróticas dos adultos, mais especificamente do comportamento adúltero de sua mãe. Esta narrativa inicia-se com a dúvida de Miguilim sobre a beleza do lugar onde mora, que só se dissipa com os óculos emprestados do doutor que o leva para a cidade grande.

Já em "Buriti", lê-se o seguinte, no diálogo que encerra o primeiro encontro entre Miguel e Maria da Glória:

$\boldsymbol{O}$ Mutum. Assim, entre a meninice e a velhice, tudo se distingue pouco, tudo perto demais. De preto, em alegria, no mato, o mutum dansa de baile. Maria da Glória sabe que pode fiar de sua beleza. Ela tem meu olhar para os seus braços. - "O senhor está com a ideia muito longe..." De onde eu sou, ela é: descende dos 
Gerais, por varonia. Minha meninice é beleza e tristeza. (B, $139 / 140$, grifos meus)

Inconteste a mistura de beleza e tristeza que marca a vida de Miguel/Miguilim, herança dos tempos do Mutum. Agora, diante de Maria da Glória, tem a oportunidade de experimentar a combinação da beleza com a alegria: "Sei que desejaria parar, demorado, perto dela. Da alegria." (B, 87), "De nascença recebera aquela alma, alegria e beleza: tudo dum todo só. Miguel gostava dela." (B, 114) O texto citado acima, aliás, já serve para ressaltar a força da alegria em detrimento da tristeza, uma vez que o pássaro mítico não se lamenta como na lenda ianomâmi, mas "dansa de baile", trajado "de preto, em alegria", como que a confirmar as derradeiras palavras de "Campo geral", quando a protagonista deixa o Mutum: "Sempre alegre, Miguilim... sempre alegre, Miguilim..."17 (CG, 103)

Mas a aproximação de Miguel em relação a Maria da Glória não se dá sem hesitação, sem o movimento de Miguel para vencer o sertão - e suas marcas - contra o qual ele luta, sobretudo contra $o$ medo: "Tenho medo de sofrer? Você acha que sou fraco?" (B, 89, grifo nosso) "[...] me travou um medo. O medo de não ser o momento certo para a encontrar. Maria da Glória era a mulher que menos me lembrava minha mãe. Ela não me lembrava pessoa alguma." (B, 128, grifos nossos) Ou, como na síntese do narrador:

Contra o sertão, Miguel tinha sua pessoa, sua infância, que ele, de anos, pelejava por deslembrar, num esforço que era a mesma saudade, em sua forma mais eficaz. Mas o sertão dos Gerais povoava-o, nele estava, em seu amor, carnal marcado. Então, em fim de vencer e ganhar o passado no presente, o que ele socorrera de aprender era a precisão de transformar o poder do sertão - em seu coração mesmo e entendimento. Assim na também existência real dele sertão, que obedece ao que se quer. - "Tomar para mim o que é meu... $(\mathrm{B}, 97)$

O que se pretende mostrar aqui é o quanto, para além dos sinais mais evidentes, o Mutum (lugar) traz, para Miguel, a marca do mutum (Mito indígena). Para que Miguel tenha o poder de tomar para si o que é seu - no caso o amor de Maria da Glória,

\footnotetext{
${ }^{17}$ As referências a "Campo geral" podem ser encontradas no volume Manoelzão e Miguilim, Rio de Janeiro: José Olympio, 1976, e serão aqui apresentadas entre parênteses com a abreviação 'CG' seguida do número de página.
} 
correspondido, mas ainda sem seu conhecimento - nada se fará sem a coragem para enfrentar seus fantasmas, alguns dos quais passam pelo escuro do Mutum que o habita: "Mas o sertão dos Gerais povoava-o, nele estava, em seu amor, carnal marcado" (grifo nosso)

Além da leitura que permite entender o crescimento da personagem no seu nível mais pessoal, parece cabível a interpretação do trecho assinalado numa dimensão maior, que diz respeito à presença do mito no texto moderno.

Quando se lê: "Vencer e ganhar o passado no presente" e a necessidade de Miguel "aprender [...] a precisão de transformar o poder do sertão - em seu coração mesmo e entendimento" é pertinente pensar numa forma de compreender a presença do passado/mito no texto moderno/presente, sendo o mito isto que está incrustado no "poder do sertão" e pede interpretação (no coração e no "entendimento"), seja no nível da história pessoal do personagem seja no nível do entendimento mais geral da novela.

A mitologia - aqui, no caso, a indígena - se faz presente nos meandros narrativos, na disposição de determinadas figuras, em trechos da novela, em referências nem sempre explícitas, elaboradas segundo o critério do autor e que pedem o trabalho de "aprender" - apreender, analisar e interpretar - o "passado no presente". Obviamente, a interpretação tem outros objetivos além deste.

O presente do texto rosiano pede, porém, a atenção para a existência destes elementos, diferente, por exemplo, de Macunaíma, em que as referências são explícitas. A modernidade do texto de Rosa está, dentre outras razões, neste desafio de adentrar o sertão da linguagem a fim de conhecê-la a fundo, desentranhando os signos que remetem seja à aurora dos tempos seja ao conflito humano mais atual. Reatualiza-se, por um lado, a força do mito, registro de um tempo imemorial e, por outro, através da interpretação, colhe-se disto que é passado a força que permite "vencer e ganhar" sentido novo, atual, "presente".

Exemplo destas considerações é a própria análise e interpretação feita aqui sobre um destes elementos do passado - tanto mitológico quanto pessoal - para Miguel: o mutum. O peso ancestral trazido pelos mitos indígenas, passa pelo local da ação de "Campo geral” e serve como meio de reflexão sobre a presença de Miguel/Miguilim em 
nova situação de tensão, desta vez propriamente amorosa. O que se observará é a própria reversão do sentido trágico e taciturno da figura da ave mítica, associada, agora, com a alegria e a dança (ou dansa, como quer o autor). O presente da ação no sertão de "Buriti" reverte a tristeza do sertão de "Campo geral" em alegria. O que se tem é o homem feito Miguel vencendo e ganhando "o passado" de sua triste meninice "no presente" feliz de sua maturidade na promessa do amor de Maria da Glória.

\subsection{1 - Mutum, Crax, Caz: o nome do pai.}

A marca carnal do sertão em Miguel, voltando ao trecho citado acima, é também simbólica, a começar pelo nome. Em "Campo geral”, Drelina discute com o irmão recém-crismado, acusando-o de mentir sobre os presentes que ele disse terem sido engolidos por um jacaré. Questionado sobre qual seria seu nome, ele responde apenas: "Miguilim”, ouvindo da irmã a seguinte resposta: “- Bobo! Eu chamo Maria Andrelina Cessim Caz, Papai é Nhô Bernardo Caz! Maria Francisca Cessim Caz! Expedito José Cessim Caz! Tomé de Jesus Cessim Caz... Você é Miguilim Bobo..." ${ }^{18}$ (CG, 9)

Patronímico pouco comum - Caz - entra em consonância com o nome científico do gênero de aves da família Cracidae à qual pertence o mutum: $\operatorname{Crax}$ (Crax alector) ${ }^{19}$. Em "Buriti", acha-se o seguinte trecho: "O mutum se acusa. O mutum, crasso. [...] O mato do Mutum é um enorme mundo preto, que nasce dos buracões e sobe a serra". (B, 115/116, grifo meu) O mutum Crax, "crasso" - espesso, grosseiro - acusa sua presença no Mutum lugar, cujo "mato [...] é um enorme mundo preto que nasce dos buracões". A junção de ambos, ave e lugar, constituem a matéria prima do qual o homem Miguel é feito, sua carne traz a marca do (M)mutum, assim como sua memória e sua afetividade.

Acrescente-se ainda, para enriquecer a significância desta aproximação, via sintaxe e homofonia, o fato de que "cras" - presente, por exemplo, na palavra "procrastinar" - é um advérbio latino que significa "amanhã". Se é plausível e legítima

\footnotetext{
${ }^{18}$ Mesmo sabendo que o sobrenome da família de fato é "Cassio" e não "Caz", por meio da leitura de "Campo geral" à página. 25 e a "Estória de Lélio e Lina", leva-se aqui em consideração o lapso, o "erro" infantil da pronúncia de Drelina que cria esta corruptela cheia de sugestões e possibilidades de interpretação no contexto da narrativa e no desenvolvimento do presente estudo.

${ }^{19}$ Conforme pesquisa no site Comitê Internacional de Ornitologia (http://www.worldbirdnames.org/ioclists/family-links/), em 23/02/2015.
} 
a aproximação destes achados - Caz (sobrenome), Crax (mutum) e o cras (amanhã), poder-se-ia dizer que Miguilim, criança em "Campo geral”, tem de procrastinar sua alegria e sua glória, deixá-la para amanhã até tornar-se Miguel, em "Buriti", e finalmente encontrar-se com Glória, a fim de "vencer e ganhar o passado no presente". ${ }^{20}$

Na passagem citada de "Campo geral", vê-se o despeito da irmã Drelina. Nenhum dos irmãos fora crismado, a não ser Miguilim, e a menina tenta excluí-lo da linhagem paterna. Sendo a crisma a confirmação do batismo, pode-se, neste ato, mudar o nome do crismado. A irmã quer crismá-lo de "bobo", mas é mais provável que se tenha confirmado o Caz. Confirma-se, dessa forma, a ligação de Miguilim ao pai, nhô Bernardo. Faça-se a ressalva de que é possível mudar na crisma o prenome do crismado, como forma de confirmar as promessas feitas pelos pais. Conta neste trecho, portanto, mais o desejo de Drelina de, mudando o sobrenome do irmão, tirá-lo da família, negando-lhe a inscrição na linhagem paterna.

Nhô Bernardo, por seu turno, deixa clara a preferência em relação a Dito, dispensando trato violento ao filho crismado. A ligação entre pai e filho, além da marca da violência - que em Miguel se manifesta na ojeriza que esta personagem tem pela caça - pode ser estendida à sina infeliz quanto a uniões amorosas. Parece cabível aqui, portanto, outra interpretação ao trecho a seguir, centro dos temores mencionados acima: "Quando Miguel temia, seu medo da vida era o da repetição." $(\mathrm{B}, 114)^{21}$

A proximidade do Caz/Crax só intensifica alguns pontos de contato entre a criança e o adulto, principalmente quando se leva em conta alguns dos aspectos já discutidos até aqui, como a vegetação e as trevas. "Miguel esperou. Devagar, recuava. Tragava o medo do mato." (B, 125) O narrador de "Campo geral" observa quanto a Miguilim: “[...] a mata, ali perto, quase preta, verde-escura, punha-lhe medo" $(\mathrm{CG}, 6) \mathrm{e}$, mais adiante, "Miguilim não gostava de por os olhos no escuro" (CG, 23) Aqui se

\footnotetext{
${ }^{20}$ A redação deste parágrafo não seria possível sem a contribuição da Profa. Adélia Bezerra de Meneses, responsável pelo esclarecimento e reflexão em torno do termo "cras" latino, por ocasião do exame de qualificação. A ela, meu muito obrigado.

${ }^{21}$ Aqui, leva-se em conta a proposta interpretativa de Ana Maria Machado com relação ao medo da repetição de Miguel, na qual a autora chama a atenção para a fala de Miguilim "O Ditinho está em Glória" e a semelhança do nome de Maria da Glória. Embora em acordo com a leitura desta autora, entende-se que este medo da repetição pode ser mais amplo, nos moldes aqui propostos.
} 
observa, no tocante à perspectiva de Miguel, a estreita relação do escuro com o medo, travo infantil que se espalha, como a noite, sobre a vida do adulto. Ademais, como o leitor de "Campo geral" bem sabe, Miguilim é míope, fato que se revela ao final desta narrativa e ajuda a entender o medo do escuro.

E é com o escuro da noite, das penas do mutum, que Miguel tem de se haver quando toma conhecimento do Buriti Bom e seus habitantes. Seu jeito calado e reflexivo, reservado - como o mutum "atoleimado, escondido em oco de pau" contrasta com a expansividade solar de Maria da Glória e é ocasião para o aprofundamento da conversa entre ambos:

“- Lá tinha pássaros cantando de noite?" “- Sério. O mutum. De dia ele fica atoleimado, escondido em oco de pau, é fácil de se pegar à mão. Mas, à noite, sai para caçar comida. Canta, antes da meia-noite e do romper da aurora. Chega dá as horas. É grande e formoso, como as penas dele brilham, feito um pavão." “- E como canta?" "- No meio do mato, de madrugada, ele geme: - Huhum... Uhu-hum... Não se parece com nenhum." "-Aqui não tem." “- É um pássaro tristonho..." "Você teve namorada, lá, em sua terra?" (B, 87, grifo meu)

“- Por que você não vem caçar? Sabe, eu não disse a verdade, de propósito: por aqui também tem mutum. Mutum no mato, ronca cismado, que até enjoa a gente... Se caça. A carne é muito gostosa... Você não gosta de caçada?" (B, 88)

Miguel sabe do que fala ao tratar do mutum, descreve a ave, conhece seus hábitos, admira sua beleza, conhece seu canto e reconhece sua singularidade. Ao observar, no entanto, que se trata de um "pássaro tristonho", projetando a tristeza de sua meninice à ave/lugar de onde veio e da qual descende, recebe, em resposta a mais radical mudança de rumo na conversa: "Você teve namorada, lá, em sua terra?"

A aproximação de Miguel com o mutum, agora via tristeza, e sua possibilidade de envolvimento amoroso merece aqui ser destacada, levando em conta a própria pregnância textual. No comentário de Gualberto sobre as filhas de iô Liodoro, o compadre "prevê" o enamoramento de Maria da Glória e Miguel, nestes termos: "Mas, Maria da Glória, o senhor sabe, pressentimento meu: ela há-de simpatizar com o senhor, de tudo me vem o palpite. O senhor é um bem-apessoado moço, solteiro, tristonho.” (B, 104 , grifo meu) 
Maria da Glória, já interessada em Miguel, vai direto ao ponto e, sem saber, toca o ponto fraco do protagonista, qual seja, a questão da afetividade, e do já mencionado medo da repetição trágica do destino paterno.

A atitude tristonha e quase de veneração de Miguel em relação ao mutum/Mutum cai por terra quando Maria da Glória o afronta com a possibilidade de saborear sua carne, propondo-lhe algo equivalente a um banquete totêmico, mediante prévio ato violento - a caça - que Miguel odeia: "Fugi de responder. O que devia ter dito: que odeio, de ódio.” (B, 88)

Note-se: Miguel não diz a Maria da Glória, e a nenhum outro personagem, o nome do lugar no qual viveu. Limita-se a dizer para Maria da Glória que: “ - É um lugar que nem sei se ainda existe, lá. Minha gente se mudou...” (B, 87) e para Gualberto: "Do alto dos gerais. Dum mato, um sitiozinho da serra... Tenho o jeito não?" $(\mathrm{B}, 100)$

Vê-se, portanto, que a restrição, ao modo de um tabu, quanto ao mutum pássaro evoca a situação vivida por Miguel no Mutum. A restrição, diga-se, é relativa, pois ainda há tempo para o registro do monólogo interno de Miguel, pouco antes do fim deste serão: “[...] daqui a pouco mais nos vamos separar, todos a dormir. Como será o quarto de Dona Lalinha? Caçam. Dona Lalinha pode ser que aprecie a carne do mutum, que é branca, mais gostosa que a do peru." (B, 90, grifo nosso)

O amor de Miguel pelos Gerais, amor "carnal marcado", passa pela prova da própria carne dos Gerais, em seu representante simbólico, o pássaro nativo e noturno. Todos os medos e cautelas herdados de sua vivência no Mutum acompanham-no e são reatualizadas na sua chegada, à noite, no Buriti Bom e seu diálogo sobre o mutum. A carne de Miguel está marcada pelos acontecimentos dolorosos registrados em "Campo geral" e isto não deve ser colocado em pouca conta quando se depara com a leitura de "Buriti", principalmente quando se atenta aos detalhes.

\section{5 - O mutum e a lua}

$\mathrm{Na}$ perspectiva da mitológica indígena, viu-se acima o aparecimento da noite associado a uma busca ligada ao impulso erótico, sexual, como forma de experimentar 
novas modalidades de encontro amoroso. Ao redor da noite, como elemento constitutivo, próximo do próprio espírito da noite, o mutum, pássaro mítico. Uma vez estabelecida a noite, é a vez de fazer surgir a lua, de presença tão extensa no imaginário indígena como nas páginas de "Buriti".

Alguns exemplos desta presença na novela rosiana seguem abaixo como referência:

- Olhe: pior, para cristão, é quando a lua tira o juízo...

- Dentro da lua, diz-que moram umas coisas...

- Tem loucura de lua e loucura de sol, Virgem Maria...(B,

209)

- Muitos morrem na lua nova... (B, 239)

Glória, Glorinha, podia dizer, pegar-lhe nas mãos, cheirar o cheiro de seus cabelos. A boca. Os olhos. A espera, lua, luar de mim, o assopro [...] $(\mathrm{B}, 250)$

O extenso imaginário popular que trata da lua pode fazer do astro celeste depositário de múltiplos conteúdos. Nos trechos acima, pode-se cogitar alguns deles: a lua como fonte de loucura, ponto de partida ou chegada dos lunáticos, seu caráter mortífero assim como o romântico. As coisas que "moram na lua", ao menos naquela encontrada em "Buriti", dizem respeito ao universo das paixões humanas, em contraponto com à razão solar, que se ocupa dos trabalhos da terra, entre roça e gado.

Mais do que tirar o juízo, se verá que alguns mitos indígenas trazem a lua como decorrência de uma "falta de juízo", desfecho trágico de uma paixão incestuosa que deixa no céu a marca da desrazão. Daí, por sua influência sobre a terra, o astro assume o contraponto com o sol que tudo põe às claras, estabelecendo definitivamente a dialética entre a iluminação - entendida em seu sentido amplo - e a noite que abre espaço, sob a tênue luz fria da lua, para as paixões, "escândalos e incestos" aos quais o "instinto humano" acede, para fazer jus ao verso de Augusto dos Anjos que serve de epígrafe a este capítulo. 
Como mais um exemplo da relevância dos elementos afeitos à noite na fatura erótica de "Buriti", é importante mencionar a lenda colhida por João Barbosa Rodrigues, em seu volume Exploração do rio Yamundá, de 1875.

Este autor, ao fazer a exploração do rio da região amazônica, acredita, a certo ponto da viagem, ter chegado à mítica terra das Amazonas, local onde se encontravam em sua grafia - as muyrakytãs. Ali, encontra uma serra denominada Acunã ou Yacy taperê (tapera da lua). Segundo ele, Yacy, a lua, é a mãe do reino vegetal, uma vez que, em tupi, "Ya" significa planta e "Cy", mãe. Explica que a origem do nome da serra se liga a uma lenda indígena, abaixo reproduzida em itálico.

Conta-se a história de uma índia que habitava a beira do lago Yacy-uaruá (espelho da lua) que se apaixonou pelo irmão, que morava no alto da serra. Em segredo, passou a visitava-lo toda noite em sua rede, protegida pelas trevas. $O$ índio, cada vez mais curioso em saber quem era aquela que o despertava para o amor, certa noite, decidiu untar as mãos e pintou as faces da jovem. Ela, que habitava as margens do lago Jacy, espelhou-se em suas águas e viu que estava marcada para sempre. Para não corar ante o irmão, fugiu para sua casa, onde pegou o arco e um maço de flechas. Manejando o arco, despediu flecha após flecha, até formar uma longa vara, e por ela subiu, transformando-se em lua. O irmão que habitava o alto da serra, indo vê-la e não a encontrando, de dor, metamorfoseou-se em mutum. Ela agora vem mensalmente, sob a forma de lua, mirar-se no espelho do lago para ver se desapareceram as manchas. Eis a origem do nome espelho da lua e tapera da lua. ${ }^{22}$

Tomando esta lenda ao lado das que falam sobre a origem da noite, pode-se lêlas numa espécie de continuum. O surgimento da noite, colado ao desejo sexual e a novas possibilidades/modalidades de desfrute da sexualidade. No breu da noite, os parceiros se encontram, muitas vezes sem conseguirem se identificar. Usa-se a noite para dar vazão aos impulsos incestuosos, só descobertos mediante um artifício afeito à

\footnotetext{
${ }^{22}$ RODRIGUES, 1875 , p. 31/32. Vale lembrar que a lagoa Jacy-uaruá era o lugar de onde as Amazonas, tiravam as muiraquitãs para presentear os índios que vinham, anualmente, para a festa na qual elas mantinham relação com a finalidade de aumentar a tribo. Em Macunaíma se lê: "Macunaíma escoteiro topou com uma cunhã dormindo. Era Ci, Mãe do Mato. Logo viu pelo peito destro seco dela, que a moça fazia parte dessa tribo de mulheres sozinhas parando lá nas praias da lagoa Espelho da Lua, coada pelo Nhamundá. A cunhã era linda com o corpo chupado pelos vícios, colorido com jenipapo." (ANDRADE, 1978, p. 21)
} 
arte, a pintura do rosto do amante secreto. A lua é resultado do desvelamento desta relação incestuosa que se torna pública. Separados de corpo pela vergonha ante a coletividade, mas unidos no plano mítico, os irmãos tornam-se companheiros inseparáveis, lua e mutum têm a noite como momento privilegiado do encontro. Pode-se daí pensar na lua, e sua influência, como signo do encontro proibido a emanar suas vibrações nas páginas do Corpo de baile.

O destino da família Caz apresenta-se, em termos do desfecho de "Campo geral" e de parte expressiva de "Buriti" no que concerne a perspectiva de Miguel, ligado à origem do mutum, Crax, nos moldes da lenda acima transcrita. Percebe-se, ademais, que o comentário de Miguel sobre o mutum como sendo um "pássaro tristonho" tem seu fundamento mítico.

Há uma pequena referência ao incesto em "Campo geral”, quando Miguilim, doente, propõe que os irmãos casem-se entre si. Ainda que em tom agônico, não se deve deixar de assinalar esta ocasião para a nomeação do desejo proibido. Parece evidente então a possibilidade de relacionar o mito acima exposto com a história de Miguilim. A marca do encontro proibido, que burla a lei da cultura ou os ditames sociais que regem as relações civis é, portanto, inequívoca, somada a menção ao incesto e a ação de Nhanina, mãe de Miguilim e seus amores extraconjugais.

Vale assinalar outro trecho significativo de "Campo geral" que, embora não seja o objeto de estudo desta tese, justifica-se devido à menção a algumas marcas que ajudam na compreensão da personagem Miguel, que serve como o disparador de toda a trama de "Buriti".

Trata-se, justamente, de um encontro entre a lua e o mutum, mais especificamente, um passeio proposto pela mãe de Miguilim, aproveitando a ausência do pai e de Vovó Izidra, agentes repressores por excelência. Este passeio se realiza à noite, sob a luz de uma grande lua no mato do Mutum: “[...] foi o dia mais bonito de todos." (CG, 65).

Experimenta-se ali, para os integrantes deste passeio no mato sob a luz da lua o mesmo esgarçamento dos limites que tanto se encontra em "Buriti", no dizer do narrador: "Tinha lua-cheia, e de noitinha Mãe disse que todos iam executar um passeio 
até aonde se quisesse, se entendesse." (CG, 65, grifos nossos) O que se tem aqui, na verdade, é a livre manifestação da vontade de uma personagem que vive a opressão e busca uma válvula de escape, uma vez que sente haver pouco espaço para o seu querer ("até onde se quisesse") e o seu entendimento ("se entendesse"). Na dança dos contrários que unem o Corpo de baile, vê-se que o que é dificuldade em "Campo geral" é relativamente facilitado em "Buriti".

O narrador prossegue, colado à perspectiva de Miguilim: "Tinha lua-cheia”, e "Quando a lua subiu no morro, grandona, os cachorros latiam, latiam." (CG, 66) A lua deixa a todos siderados. Miguilim, de sua parte, busca a proximidade com a mãe. Mas logo ao começo do passeio anota-se que: "Mãe ia na frente, conversando com Luisaltino."

A conversa não poderia ter caráter mais sugestivo e sedutor, uma vez que o homem começa por reprovar o costume dos pais casarem as filhas muito novas, sem que estas tivessem a oportunidade de escolher os noivos, numa sutil evocação do passado de Nhanina e num velado convite ao adultério. Este passeio e a conversa entre os adultos podem remeter, por seu teor, à entrevista noturna e sedutora entre Lalinha e iô Liodoro, convite ao incesto. É necessário anotar também as devidas diferenças, sobretudo quanto ao ambiente fechado e ao caráter particular dos encontros em "Buriti".

Não por acaso o passeio noturno de "Campo geral" marca uma virada na trama da novela. Uma série de eventos classificados por Dito como "o tempo-do-ruim" culminará com a morte desta personagem. Daí que a noite do passeio, tão marcante para Miguilim, possa reverberar ainda no homem Miguel, pois a noite pode marcar tanto a beleza quanto aquilo sobre o que não se pode ter controle.

Já foi dito que em "Buriti" alguns interditos sociais em relação à sexualidade encontram um ponto de suspensão. No encontro de iô Liodoro com a nora, a quem trata por "minha filha", assim como na iniciação sexual de Maria da Glória pelo compadre substituto paterno - nhô Gualberto, vê-se inequívoco o sinal do incesto.

Note-se que o relato destes eventos acima mencionados, na segunda parte de "Buriti", exclui a presença de Miguel. Este, portanto, ignora totalmente o que se passara no Buriti Bom, uma vez que é entre o período de tempo entre sua primeira visita e seu 
iminente retorno que se passa toda esta parte. Pode-se considerar aqui, embora em caráter conjectural, que a ignorância é uma bênção que certamente facilita, ou mesmo propicia, a aproximação de Miguel para, candidamente, pedir a mão de Maria da Glória. Caso ele soubesse que ali, como no tempo/espaço de sua meninice, os adultos se comportam de forma tão desregrada, manter-se-ia firme em seu propósito, principalmente se soubesse que sua amada tomara a iniciativa para perder a virgindade com Gualberto, de quem ele se considera vero amigo?

Caberia perguntar o que se passa nessa segunda parte de "Buriti". Verdadeiramente, a fábula. Algo fantástico, extraordinário e, por este viés, algo que se aproxima do mito. Reforça-se a ideia de uma narrativa composta como um sonho que remete a um tempo de origem, no qual a possibilidade de fruição sexual é distinta daquela circunscrita no padrão civilizado stricto sensu.

Faça-se a ressalva de que o plano mítico, referência aos primórdios da humanidade, serve aqui como pano de fundo, não sendo este o destino das personagens. Estes, em "Buriti", buscam à sua maneira discriminar-se do "amontoo" - a larga herança autóctone brasileira - para uma busca no sentido de gerirem a si próprias como personagens.

\section{6 - Da lua ao lampião: um desfecho}

O caráter noturno e a influência da lua no desenrolar de "Buriti", já assinalados pela estudiosa Heloísa Vilhena de Araújo em seu A raiz da alma, mostram-se insidiosos e cheios de consequências, principalmente quando se procura saber que lua é esta. Para esta estudiosa, marca-se em "Buriti" a predominância do feminino, ligada à lua, à agua e à fertilidade. Da mesma forma, na vigência lunar desta novela, circunscreve-se a possibilidade de Lalinha e Maria da Glória experimentarem o desfrute da sexualidade adulta num ambiente "protegido".

No entanto, esta pesquisadora não menciona, ou não nomeia com propriedade, $o$ que significa esta experimentação, a saber, fenômenos afeitos ao espectro incestuoso do comportamento das personagens. Ao contrário, Araújo insiste na possibilidade dessa 
experimentação ter um caráter positivo, pois a sexualidade, num primeiro momento, "assusta a ninfa", pois com sexo vem o mal. Como se experimentar o sexo e o erotismo com uma figura paterna, ou um substituto deste, não pudesse assustar, na medida em que representa um tabu, o mal inerente à sexualidade.

Trata-se, na realidade, de fazer aqui um adendo à exposição de $A$ raiz da alma, pois, principalmente nas divagações de Lalinha pode-se perceber, mesclado com a naturalidade do ritual noturno, a angústia, principalmente à medida que se aproxima o desfecho da trama: "seu sentir era uma lâmina capaz de decepar no espaço uma melodia. E teve medo. Um medo pavor, como se seu ser de repente não tivesse paredes." (B, 231)

Pensando especificamente na figura da lua, muitas podem ser as fontes de entendimento, uma vez que diversas lendas dos índios brasileiros - para ater-se ao repertório usado neste capítulo - falam da origem da lua. Chama a atenção, porém, a constância da temática do amor incestuoso e o aparecimento do satélite em algumas destas histórias.

Exemplo semelhante ao da lenda citada por Barbosa Rodrigues é um mito colhido por Betty Mindlin (2007, p. 44/46) entre os índios Suruí-Paiter, a partir da narração de Dikboba Suruí. Com poucas variantes, conta-se a história de uma jovem, prometida em casamento, que começa a receber, à noite, em sua rede, a visita de um amante misterioso. Decidida a descobrir quem era, pinta-lhe o rosto com jenipapo sem que ele se dê conta. Descobre, por fim, que o irmão amanhecera com o rosto manchado de jenipapo. Irmão e irmã decidem subir ao céu por um cipó, por sugestão da mãe, e transformar-se na lua, sendo a face escura do satélite o rosto do irmão manchado de jenipapo.

Outra versão, registrada em Moqueca de maridos e também colhida por Mindlin (1998, p. 77/78), a partir da narração de Uberiká Sapé Macurap traz o mesmo namoro incestuoso relacionado ao aparecimento do astro. A diferença aqui diz respeito à época em que os homens menstruavam, fato natural antes do namoro entre os irmãos. Quando o irmão aparece com o rosto pintado, este decide fugir ao céu e virar a lua, Uri. A partir deste momento, a moça, após contemplar o amado no céu, volta à sua maloca e percebe ter menstruado. 
Aliando este breve levantamento com o que se lê nas páginas de "Buriti", parece inegável anotar a questão da fertilidade associada à lua, da mesma forma que se observa certa constância entre a questão do incesto. Percebe-se que a presença deste astro, sua insistente menção ao longo da narrativa aliada aos outros elementos naturais aqui já analisados, só faz potencializar o sentido do erotismo que constitui a novela.

A suspensão de certos tabus, seja pela aquosidade do terreno e as emanações vegetais que ajudam a dissolver as barreiras socialmente constituídas, seja por todo o corpo que compõe a noite e sua conotação sexual, ou mesmo pela influência lunar, em sua evocação do proibido, dão a especificidade do texto. Identifica-se aqui a tessitura, o grosso tecido narrativo fortemente amarrado, coeso na sua distribuição de signos que evocam o caráter excepcional dos acontecimentos desta segunda parte de "Buriti".

No serão de Lalinha e iô Liodoro a lua, indiretamente, se faz presente, selando com sua pálida luz o encontro proibido. Iluminados pela dupla presença dos lampiões de Lalinha e Liodoro, pequenas fagulhas lunares, a escuridão não é total. Graças a isto se torna possível a relação em toda sua exuberância voyeurística/exibicionista, diferente do encontro mítico, às cegas. Aqui, o evento incestuoso se dá com razoável dose de conhecimento mútuo e inteligibilidade.

Ela saíra do quarto, segurava o pequeno lampião, pouco maior que uma lamparina. [...] Ele empunhava o lampeão grande. [...] Ele depusera o lampeão grande na mesa, e ela o imitou, colocando bem perto o lampeãozinho. $(\mathrm{B}, 211)$

Adiante, no corredor, bruxeava a candeia na parede, sob a imagem de um santo. Aquela luzinha, frouxamente [...]

E havia luz, na sala. Seria ele? Lalinha se ajeitou, resoluta. Pegara a lâmpada. Ia. Caminhou, queria ter o ar de que não ia com intenção [...] $(\mathrm{B}, 214)$

Deixara o lampeãozinho na mesa, no mesmo lugar da outra noite, ao pé do lampeão grande.

Na mesa, o lampeãozinho junto do lampeão grande, as luzes agrandadas. $(\mathrm{B}, 219)$

Da mesma forma, no encontro final entre estas personagens, após a chegada da carta que anunciava o nascimento do filho de Irvino, o lampião testemunha a 
consumação do encontro amoroso, liberados enfim do peso dos laços familiares que impediam a realização de ambos na condição de amantes.

Ainda era maio. Estrelava. Ali, o jardim, de Deus, o laranjal, a noite azulante. Lala fechou a janela. Toda se preparara, de estudo. Agora se despia. Sim, ia espera-lo desse jeito, sobre as roupas do leito, em carne. Sim, pouco somava com o friozinho, que arrepiava um tanto. Seus seios. Mas, ele, se viesse, teria de achala assim, dizendo de vencido pudor, de desejo e liberdade. Já era tarde. A porta encostada, o lampeão aceso com a chama baixa. $[\ldots]$

- “Alecrinzinho, é. O amor gosta de amores...” [...]

- "Mocinha virgem, na noite do dia, só quando deita na cama é que perde o bobo medo..." (B, 244, grifos meus)

Juntos, elementos vegetais e signos noturnos se encontram e compõem a atmosfera do encontro. O jardim, "de Deus", outra referência ao Éden, mostra sua conformação de "lugar de agrado", cheirando a alecrim. A "noite azulante" estrelava e o "lampião com a chama baixa", tênue iluminação, como a lua, guiam o desejo e a liberdade no momento pleno de afirmação, marcado pelo "sim" duas vezes repetido no curto trecho.

No entanto, antes deste momento, ápice do jogo erótico encetado entre Lalinha e iô Liodoro, a consumação amorosa é substituída, mais uma vez, pelo véu das palavras veículos do desejo - à maneira do que foi dito no capítulo precedente. Agora, com toda a exuberância semântica e sonora, sogro e nora "encontram" um "brinquedo", excitação sexual que passa pela carícia do olhar e a sucessiva nomeação das delícias percebidas, como um jogo de preliminares.

Note-se que o "brinquedo" de Lalinha e Liodoro passa pelo gozo tanto do corpo que se dá a ver e é visto como da palavra dita e ouvida, estando aí, nesse intercâmbio do que entra e sai pelos sentidos - sem o contato direto entre os corpos - o ato sexual possível naquele momento. Não deixa de haver, portanto, à sua maneira, o intercurso entre sogro e nora sob a luz do lampião, sucedâneo da lua que contribui para tirar o juízo das personagens, pois proporciona a luz suficiente para manter o encontro na discrição ao mesmo tempo em que alimenta o espetáculo particular. 
Já não há o breu total da noite que cerca e propicia o encontro sexual dos irmãos da mitologia. Em "Buriti", no interior da Casa (grafada muitas vezes com maiúscula, como se ela também tivesse o estatuto de um personagem), sob a luz do lampião - luz produzida artificialmente, marca da cultura - o encontro do patriarca e sua "filha", neste ponto, é mediado pela palavra carregada de sentido erótico, que compõe, com o olhar, esta cena decisiva para o desfecho da novela.

Tal encontro, porém, por sua riqueza de significados dentro da narrativa, não caberá analisar aqui. Frise-se, de qualquer forma, que esta sucessão de encontros, ponto máximo do erotismo das Noites do sertão, é a culminância deste mesmo erotismo espalhado prodigamente nos diversos elementos da natureza, entre céu e terra, animais e vegetais, plenos de significação, erotismo que nos remete a tempos imemoriais.

O mito, em "Buriti”, mostra sua força, seu poder de emanação simbólica, ao mesmo tempo em que, em contato com questões afeitas ao tempo histórico, ganha novos sentidos e nuances. Seja a origem do homem, barro animado pelo sopro úmido e que acorda num "lugar de agrado", ou dos fenômenos que participam dos primórdios do seu percurso sobre a terra, na noite que cega e assusta, na lua que sinaliza o (des)encontro dos amantes, a pena de Rosa nesta novela não poupa esforços para mostrar a complexidade, o corpo deste fenômeno chamado Amor, com suas velhas e novas demandas. 
Capítulo 3 - Os clãs e seus totens. 


\section{CAPÍtULLO 3}

\section{Os clãs e seus totens}

"De preto, em alegria, no mato, o mutum dansa de baile" (B, 139/140)

“O Buriti-Grande: que poder de quieta máquina era esse, que mudo e alto maquineja?” (B, 114)

\section{Introdução}

A força simbólica de alguns elementos ligados à natureza literariamente constituída de "Buriti" foi estudada nos capítulos precedentes. A relevância da flora e dos elementos ligados ao solo, assim como a noite, os sons e a lua que dão materialidade ao seu corpo, forneceram dados importantes para pensar a singularidade do elemento erótico construído por Rosa nesta narrativa.

Dentre estes elementos podemos notar, além da evidente importância da palmeira nativa que nomeia a novela e compõe a ambientação e a valoração erótica desta, a invocação do mutum, presentificado no personagem Miguel, herdeiro do sangue Caz/Crax e da terra, Mutum, que marcam sua história de vida de forma decisiva.

Como decorrência do argumento central desta tese, de que o erotismo de "Buriti” guarda estreita relação com as emanações do próprio sertão, todo ele propiciador de signos eróticos, tome-se agora os grupos familiares - de Maria da Glória e de Miguel - como frutos desta terra fértil que é a ficção de Rosa, mais especificamente como clãs regidos por totens específicos, a saber, o mutum e o buriti.

A partir desta etapa da pesquisa, neste e no próximo capítulo, ficará mais evidente o encontro do homem com a terra, da natureza impregnada de erotismo abrindo espaço para que o sujeito humano vivencie o seu próprio. Em muitos momentos, ficará evidente que as personagens, atuadas pelo erotismo natural, experimentam a relação com seus próprios desejos e o encontro com o outro em uníssono com o elemento natural.

Cada um destes clãs, ao seu modo, e de acordo com as características próprias de cada totem que os representa, manifestam e lidam com o erotismo de forma particular, como se verá. Nas páginas de "Buriti" encena-se o encontro - pleno de consequências interpretativas - do filho do mutum com a flor do buriti, cujos caminhos se cruzam, 
num primeiro momento, por obra do acaso. Para tornar mais produtiva esta proposta de leitura, alguns trechos de "Campo geral" serão apreciados em paralelo com os de "Buriti".

Desde já faça-se a ressalva de que se trata - o totemismo fazendo parte da fatura literária destas obras de Guimarães Rosa - de um constructo com finalidades analíticas e interpretativas. Não se verá, em parte alguma do entrecho narrativo, os personagens afirmando sua filiação a este ou aquele clã sob a influência e proteção do totem 'a' ou 'b'. Observar-se-á, no entanto, o sobrenome das personagens envolvidas (Maurício Faleiros/ Bernardo Caz) além da questão da "descendência" do sertão, "por varonia", expressões plenas de sentido e que se mostram pertinentes como suporte da leitura aqui proposta.

A possibilidade de usar o conceito de totemismo, ainda que de forma analógica, vem também, em parte, de uma formulação do professor Luiz Roncari (2013, p. 109), que em seu recente estudo sobre "Buriti" menciona as "influências totêmicas" do Buriti-Grande que "regem" a vida amorosa dos habitantes do Buriti Bom e da Grumixã.

Este "totemismo literário", se é permitida a expressão, não se dá de forma absoluta. Lalinha, vinda da cidade, é estranha a este cenário e sua inserção na dinâmica do sertão terá consequências decisivas. Guiada mais por seu desejo do que por qualquer sorte de "descendência por varonia", a segunda parte da narrativa incluirá o ponto de vista de Lalinha que se chocará com a vida infinitamente cíclica da roça. Daí a importância do elemento temporal para compreender a importância de Lalinha na narrativa.

O Buriti Bom, caracterizado como "um belo poço parado", no qual se vive o erotismo que emana da natureza, será marcado por uma experiência temporal mais afeita àquilo que é cíclico, fechado em si mesmo, mítico. A contraposição a esta condição, colocando em choque o eterno retorno do mesmo, e que contribuirá para uma abertura deste "poço" ao fluir do tempo Histórico, é a presença de Lalinha, estranha ao sertão e que trará as marcas de uma regência não totêmica, mas sujeita ao próprio desejo. 


\section{1 - Os totens: casamento dos opostos}

Mais uma vez, o estudo de Heloísa Vilhena de Araújo, A raiz da alma, pode ser tomado como referência e ponto de partida para a presente interpretação da obra rosiana. Considerando a relação das narrativas de Corpo de baile com os diferentes corpos celestes, proposta por esta autora, a infância de Miguel/Miguilim teria o sol como regente, cabendo a regência lunar a "Buriti". O fim desta novela, com o início de um novo dia e a chegada de Miguel ao Buriti Bom, sinaliza o recomeço, desfecho de um ciclo e possibilidade de um início que dá novo sentido ao percurso das narrativas/astros celestes.

Mas, justamente, se "Campo geral" trata da infância, o início da vida e seu espectro solar, insinua-se ali o aspecto noturno ligado ao mutum, ave mítica, que nomeia o espaço da ação. Além do que já se falou sobre a associação do mutum com a noite e a sexualidade nos mitos indígenas, pode-se aqui evocar outra menção plena de significado para tipificar a presença do elemento noturno na narrativa em questão, a saber, a afirmação da personagem Macunaíma, de Mário de Andrade, sobre o Cruzeirodo-Sul, ou Pauí-Pódole, ser o pai do mutum.

Em "Buriti”, por sua vez, inegável é a relevância da noite e da lua, como já se demonstrou aqui e em outros estudos. Chama a atenção, no entanto, o fato do buriti servir para nomear esta novela, uma vez que a palmeira resplandece sob a luz do sol e precisa dele para verdejar, dar frutos e, em sua materialidade mais imediata, figurar a fertilidade e os encontros amorosos, tanto de noite quanto de dia.

"Campo geral” é marcado pela dureza da infância de Miguilim, que, em meio à pobreza material de sua família, soma-se a perda do irmão e do pai. O protagonista se salva por seu poder e capacidade de fabulação e por uma intervenção do acaso, na figura do doutor da cidade que o tira do lugar de origem para, literal e simbolicamente, ampliar- lhe os horizontes.

Os membros do clã do Buriti, por sua vez, opostos à dureza da vida da família Caz, vivem na abundância material ("iô Liodoro possui um município de alqueires"), na fartura das águas, da fertilidade e da sexualidade relativamente mais liberal. Com a exceção de Maria Behú, todos têm uma vivência da sexualidade que põe em questão, 
em certos aspectos, alguns padrões mais conservadores da sociedade patriarcal brasileira.

Liodoro é o "garanhão ganhante" de todas as mulheres. Neste sentido ele encarna o padrão conservador da sociedade patriarcal. Mas em seus filhos, nova geração, se por um lado desce "por varonia" a mesma prodigalidade erótica, há espaço para a flexibilização de alguns padrões. Maria da Glória, sua legítima herdeira, não se contenta com sua condição de moça donzela. Irvino deixa o casamento com Lalinha para assumir outro relacionamento, sem dar maiores satisfações. Ísio dá "um meio desgosto" à família, pois se casa com iá-Dijina, ex-prostituta, e com ela vive "em anjos", tal e qual Soropita e Doralda de "Dão-Lalalão". Breve síntese da moral sexual deste clã. Leve-se em conta que "ali nada podia acontecer, a não ser a lenda", inclusive a possibilidade de uma vivência incestuosa, ainda que deslocada, tanto no caso de Lalinha e Liodoro quanto no de Glorinha e Gualberto, compadre de Liodoro.

De qualquer forma, Maria da Glória, na visão de Lalinha, deve ser salva, liberta das amarras familiares do Buriti Bom, tirada de seu viscoso envolvimento sexual com Gualberto, cabendo esta missão ao arcanjo Miguel que, por acaso, tomara conhecimento da então donzela Glorinha.

Mesmo a situação de Maria Behú, em meio a toda sua carolice, merece ser vista em perspectiva. Entre rezas e penitências, figurando como que o negativo da atitude predominante dos demais membros da família, ela ainda consegue sua nesga de prazer:

Ela até ajuda, com rezas maiores, com mortificações. E oração de Behú vale muito... [...] Aceitavam que Maria Behú por todos arcasse penitências. Parecia justo. Ela - a feia, sem nem um singelo atrativo - era a que se vestia sempre de escuro, e as golas tão altas, e contudo com rendinhas, que ao queixo lhe chegavam. Para proteger a santa-pureza; e de tudo aquilo, tiraria a Behú um lado de contentamento? ( $\mathrm{B}, 170$, grifo meu)

Maria Behú gostava de rezar e de ser triste (B, 176, grifo meu)

Maria Behú que recolhia para suas rezas os pecados de todos (B, 213 , grifo meu)

Maria Behú, no centro de diversa região [...] Maria Behú era uma estranha, sua doçura vinha de imensa distância. Maria Behú 
conhecia outros cansaços e consolos, e repouso, que a gente podia amenamente invejar, oh, às vezes. ( $\mathrm{B}, 222$, grifo meu)

O "lado de contentamento" é colocado no texto em forma de pergunta, como uma dúvida que se interpõe a algo aparentemente translúcido e evidente por si mesmo. E é sobre este tom de dúvida, de suspeita, de quem pergunta antes de afirmar, que pode (e deve) recair o tom da leitura. Para Maria Behú, aparentemente, não interessa o êxtase sexual, uma vez que sua ação busca o que registra o narrador por ocasião de sua morte: "a morte a embelezara" (B, 238).

A presença do prazer onde ele aparentemente não existe, de fato, aparece no texto de forma muito sutil, nas entrelinhas, nos detalhes. As rendas, "rendinhas", detalhe aparente da vestimenta de Behú, que remete ao interior e ao contato com o corpo, aqui, aparece para "proteger a santa pureza", de onde se emenda, na sequência, a pergunta acima referida.

Curioso, no entanto, é o resultado de uma associação deste trecho com outro, referido pelo narrador, próximo à perspectiva de Nhô Gualberto, a respeito de Lalinha: "Iô Liodoro não fazia mal em deixar assim, dentro de casa, a nora, com delúsios e atavios da cidade? O exemplo dela não ia cassar a virtude das filhas, de Maria da Glória? Ninguém sabe em que roupas de rendas o diabinho-diabo se reza..." (B, 110, grifo meu).

Ou seja, o mesmo adereço usado para a sedução, ação do diabo que tenta e "se reza" (se invoca, se faz presente), serve de esteio para apoiar a proteção da santa pureza de Behú. A renda que tenta a pureza é a mesma que a protege, assim como a reza que afasta o diabo é a mesma através da qual ele pode aparecer. Observa-se uma vez mais o jogo de polarizações, de reversões de sentidos usuais em seus contrários, o que só reforça a ideia do casamento, muitas vezes improvável, dos opostos.

No caso da "renda", assim como no da "reza" - significantes trazidos a guisa de descrição de Behú, mas encontrados no trecho acima destacado noutro contexto - além da proximidade sonora dos termos que garante a musicalidade da frase, alternando sibilantes e guturais (Ninguém sabe em que roupas de rendas o diabinho-diabo se reza), percebe-se pequenos índices de uma relação mais complexa. Trata-se da manifestação 
do prazer erótico na narrativa, seja no encontro dos amantes, já exaustivamente elencado, seja na beatice de Maria Behú.

Trata-se de uma prodigalidade erótica que se manifesta pelo avesso, mais próximo a uma formação sintomática do que da fruição do impulso propriamente dito. Do embate entre as forças pulsionais e a censura consciente, resulta a "solução de compromisso", possibilidade de satisfazer ambos os lados, mas que deixa o sujeito prisioneiro desta condição, popularmente conhecida como neurótica. ${ }^{23}$ Sem a intenção de rotular a personagem numa psicopatologia própria, vale aqui assinalar o lugar de Maria Behú na narrativa como esteio da moralidade, à margem da tônica familiar.

Não é à toa que a morte de Behú marca a virada que levará à realização sexual tanto de Maria da Glória quanto de Lalinha, confirmando o caráter transgressivo do erotismo que até então se mantinha interditado por "um fio" (B, 230). Ou, mesmo antes, quando do adoecimento de Behú, pouco antes de morrer, há ocasião para que Gualberto "suje" Glorinha e esta, ao procurar Lalinha, acabe sendo beijada e trocando afagos com a cunhada.

Em perspectiva contígua à desta pesquisa, Erich Nogueira (2014, p. 125 e seguintes), em sua tese de doutorado, articula o que ele chama de "voragem noturna", a massa sonora que envolve o Buriti Bom e a capacidade de Chefe Zequiel, sentinela apto a "escrutar" a "treva falando nos campos" e traduzir o quanto possível este recado aos habitantes locais. À medida que o Chefe adoece e a "voragem" chega à "Casa" há a ocasião para que o "desejo transgressor" se realize por parte de alguns personagens, com a exceção de Behú. Este mesmo autor pontua, de forma pertinente, a associação de Behú com o lado negativo, terrível da noite - e não sua face erótica como vem sendo exposta aqui - condensada na figura da coruja.

Este pássaro noturno - assim como o mutum - carrega uma conotação negativa que, no caso de Behú, marca o lugar do interdito, da morte em vida que se opõe ao chamado noturno para o amor. Behú, na contramão dos demais, tira seu prazer das

\footnotetext{
${ }^{23}$ Ao escrever a Edoardo Bizarri para esclarecer passagens difíceis de "Buriti", Rosa trata da "aversão" que o Chefe Zequiel tem de Maria Behú, apesar de esta personagem ser "a mais bondosa para com ele". E acrescenta: "Mas a Behú tem seus recalques. Quando Maria Behú morre, mais tarde, terá sido só por acaso que na mesma ocasião o chefe se viu curado?” (ROSA, 2003, p. 107, grifo meu)
} 
rezas, das penitências: "Maria Behú gostava de rezar e de ser triste” (B, 176, grifo meu) Enquanto para os demais membros da família a prodigalidade erótica é a regra, Behú é o contraponto, garantia da manutenção da "roda travada" familiar e, pode-se dizer, o último dique que impede que o "belo poço parado" transborde, exceda seus limites.

Retomando o pensamento de Araújo, faz-se necessário, então, estabelecer aqui o contraste entre a dominância solar de "Campo geral" com o aspecto noturno e suas nefastas influências da regência do negro mutum. De forma semelhante a noturna atividade erótica de "Buriti" é regida pela solar palmeira e sua pródiga fertilidade. O que em "Campo geral" é vivido em meio à culpa e com desfecho trágico, em "Buriti” é experimentado com prodigalidade.

\section{2 - Os filhos deste solo}

Miguel e Maria da Glória têm em comum a descendência "dos Gerais, por varonia." (B, 140 - grifo nosso). As consequências desta descendência, para cada uma das personagens, são facilmente constatadas a partir das considerações já feitas até aqui, e são, a princípio, de naturezas opostas. Para Miguel, a tragicidade e o aspecto taciturno, para Maria da Glória a alegria e a expansividade sexual herdada de iô Liodoro.

Da mesma forma, seja em relação à carne do mutum - da qual Miguel já provara - ou à carne do "Buriti", faz-se referência ao mesmo cerimonial que garante a união entre os membros do clã, numa clara alusão a eucaristia, versão mais recente do banquete totêmico:

O Chefe falava do buriti-grande, que se esse fosse antiquíssimo homem de botas, um velho capataz, de repente, dobrar as pernas estirava os braços, se sentava, no meio da vargem. Morto, deitado, porém, cavavam-lhe no lenho um cocho, que ia dessorando até se encher de róseo sangue doce, que em vinho se fazia; e a carne de seu miolo dava-se transformada no pão de uma grumosa farinha, em glóbulos remolhada. (B, 126, grifos meus) 
Ou ainda no doce de buriti, feito por ià-Dijina - cujo nome e pessoa são tabus para o clã do buriti - como iguaria a garantir a celebração coletiva de mais um ritual este cristão - por ocasião do $\mathrm{Natal}^{24}$ :

Ainda no dia, iô Ísio trazia o doce-de-buriti, tão belo, tão asseado - aquele doce granulado e oleoso, marrom claro, recendendo a tamarindo e manchando-se, no oscilar, como azeite de dendê: assim só as mulheres sertanejas acertavam de o preparar, com muito amor. Todos sabiam: a mulher - ià Dijina - o fizera; mas iô Ísio não ousava mencionar-lhe o nome. $(\mathrm{B}, 183)$

Lévi-Strauss (1986, p. 40), ao fazer uma síntese sobre o totemismo, reflete sobre a associação dos clãs totêmicos com o elemento da natureza eleito para representar o clã. Para o antropólogo, secundando o pensamento de Firth e Fortes: "as razões da escolha de certas espécies animais ou vegetais residem numa analogia objetiva, intelectualmente percebida". No desenvolvimento de seu raciocínio, ele expõe a proximidade desta forma de escolha do animal totêmico com o nascimento da metáfora, na medida em que, para estes povos, a escolha de certos elementos representativos da natureza designam "relações lógicas, às quais a diversidade de espécies animais serve como suporte.”(Idem, p. 42) Identifica-se aqui, segundo este autor (2010, p. 109), o caráter de "mediação entre natureza e cultura, que é uma das funções distintivas do operador totêmico [...]"

Por isto, ainda segundo Lévi-Strauss, os animais totêmicos "oferecem um meio sensível de expressar relações entre conceitos." Desta forma, ele prossegue, para um estudo aprofundado da relação dos grupos sociais com seus totens faz-se necessário o acesso ao conhecimento acumulado por estes povos no que diz respeito a cada um dos elementos da natureza. Ele escreve (1986, p. 43):

Toda investigação sobre a organização social, a vida religiosa, a atividade ritual e o pensamento mítico exige uma grande familiaridade com essas etnomineralogia, etnozoologia, etnobotânica, que não podemos estar seguros de que continuarão por muito tempo acessíveis a nós.

\footnotetext{
${ }^{24}$ Pode-se cogitar que este tabu, além de apontar para a mulher de Ísio ter sido meretriz, relaciona-se, aqui, inclusive com o fato dela, "com muito amor", dominar a técnica de transformar o fruto do buriti num doce que nenhum dos membros deste clã consegue fazer.
} 
Faça-se a ressalva, evidente, de que não se trata aqui de um estudo antropológico sobre uma população aborígene, mas de um excerto teórico para o estudo de um clã literariamente constituído. O que não elimina a relevância da analogia aqui proposta com os achados antropológicos sumariamente expostos acima. Trata-se, antes, de estabelecer um paralelo entre estes aspectos do totemismo tais como descritos por LéviStrauss e o que se observa nisto que, aqui, na obra de Rosa, funciona de forma análoga aos clãs das populações estudadas. Desta forma, a familiaridade com a "etnomineralogia, etnozoologia" e "etnobotânica", podem, relativamente, ser substituídas pela mineralogia, zoologia e botânicas literárias, tais como constituídas no arcabouço criativo do escritor mineiro.

Da mesma forma, o sentido e o tratamento dado ao termo totemismo não são aqui tomados stricto sensu do campo da antropologia. Para a consecução dos objetivos propostos neste estudo, não se fará referência aqui, por exemplo, à dimensão religiosa afeita a este fenômeno ${ }^{25}$, privilegiando a faceta relativa aos laços sociais que unem os membros do clã. Restringe-se a noção de totem, para fins de análise e interpretação de "Buriti", à estrita relação simbólica, mediadora entre a figura representativa do totem e o grupo familiar em questão, levando-se em consideração os efeitos do primeiro sobre as características e o modo de funcionamento das personagens membros destes clãs na fatura literária de Guimarães Rosa.

Em todo caso, é importante mencionar a dimensão sagrada relativa ao Buriti Grande, feito já realizado pela crítica rosiana ${ }^{26}$, enquanto representante da árvore cósmica. Para Mircea Eliade (2010, p. 124), a escolha da árvore a simbolizar o Cosmos, via experiência religiosa, se relaciona com a "capacidade infinita de se regenerar", carregando o sentido de "regeneração, de eterna juventude, de saúde, de imortalidade."

Exemplos da relação do totem com os respectivos grupos familiares mencionados acima são as epígrafes deste capítulo.

\footnotetext{
${ }^{25}$ Para uma discussão mais aprofundada sobre esta questão, inclusive sobre a crítica de Lévi-Strauss à face religiosa do totemismo, vide a introdução e o capítulo 5 do volume Totemismo hoje, deste autor.

${ }^{26}$ Conforme MENESES, 2010, p. 130. Em perspectiva distinta, mas também relacionando o Buriti Grande ao sagrado, remeta-se ao estudo feito por RONCARI, 2013.
} 
"O Buriti-Grande: que poder de quieta máquina era esse, que mudo e alto maquineja?" A aproximação do buriti totêmico a uma "quieta máquina" que "mudo e alto maquineja" dá a dimensão da influência da palmeira sobre os que vivem sob sua égide. Este "poder", cujo pleno significado parece escapar ao narrador e às personagens, a princípio indefinido, mas aparentemente certeiro como algo existente, é sentido na sua muda e alta maquinação. Esta bela metáfora aponta para o paradoxo de algo que, em meio aos barulhos da noite se imiscui mudamente, mas ainda assim se faz irresistivelmente audível, porque precede a esfera dos sentidos e atinge o âmago das personagens que compõem este clã, movendo-os para suas ações de forma inexorável.

Ou, de forma semelhante, a alegre "dança de baile" do mutum, frase lapidar que conjuga o nome do ciclo de novelas (Corpo de baile) com a coreografia da ave mítica, como a prefigurar o movimento de dispersão das personagens que integram o clã Crax/Caz, culminando com a chegada de Miguel ao Buriti Bom. Em "Buriti", a alegria da dança do mutum, contrastante com a tragicidade de "Campo geral", aponta para mais uma reversão de polaridades e associa-se com o encontro de Miguel com Maria da Glória e sua alegria, indicando a possibilidade de um novo núcleo familiar.

Mostram-se produtivas, portanto, do ponto de vista da crítica literária, as observações acerca do caráter metafórico dos elementos que servem como representantes daqueles clãs. Conforme o exposto sobre a relação dos mitos indígenas com as figuras que fazem parte do desenvolvimento da trama de "Buriti", é possível, ao modo do que se estabelece com os achados das diversas tribos estudadas, entender o mutum e o buriti como sendo estes elementos que se oferecem como suporte "de relações lógicas" relativas à composição da narrativa e da obra do escritor mineiro como um todo. Não por acaso, portanto, o entendimento da função mediadora entre natureza e cultura do operador totêmico mostra sua pertinência para a leitura aqui proposta sobre a relação do elemento erótico presente, em "Buriti”, tanto nos personagens quanto no ambiente em que estes vivem.

\subsection{1 - A palmeira}

[...]a palma-real, com a simpleza de todo dia, imagem que se via, e que realegrava. [...] Para levar o prazer de o sentir ali, nem se carecia de o olhar demorado. A gente ia passando. Mas ele deixava, no corpo e no espírito, um rijo doce-verde sombreável, que era o bater do coração, uma onda d'água, um vigor na relva. Aquele coqueiro crescido 
consolava mais do que palavras procuradas num livro, do que um bom conselho de amigo. Assim em deixação, só ser - como um rio se viaja. $(\mathrm{B}, 144)$

Dentro da obra de Guimarães Rosa poucos elementos da natureza são tão significativos como o buriti. O estudo pioneiro de Cavalcanti Proença (1959, p. 198/199) sobre Grande sertão: veredas estabelece a associação entre a palmeira e o caráter suave, de remanso, ligando a beleza dos buritis aos verdes olhos de Diadorim. Do ponto de vista da natureza mesmo, a palmeira nativa guarda íntima relação com as águas, sendo indicativo das veredas do cerrado, conforme a correspondência do autor com o tradutor Edoardo Bizarri (ROSA, 2003, p. 41).

Se por um lado há a relação com a fertilidade, com a beleza da palmeira que se ergue ao céu, há também o aspecto traiçoeiro ligado ao fato destes cursos d'água indicados pelo buriti serem também morada de grandes cobras, que vivem à espreita. Além disso, embora indiquem a presença de água, a vereda, propriamente dita, é também lugar intransitável, sinônimo de atolamento, de obstáculo, segundo o estudo de Ana Luiza Martins Costa (2002, p. 42).

O Buriti Grande, por sua vez, garante de forma inequívoca sua função de totem daquela família em particular. Já se falou de suas emanações eróticas e de sua aproximação com a índole amorosa do patriarca, desde as relações contidas em seu nome - Liodoro Maurício Faleiros ${ }^{27}$ - sua ascendência - "sendo Maurícia sua mãe, que no meio dos Gerais residia" ( $\mathrm{B}, 131)$ - até a herança que desce "bem herdada" a Maria da Glória. Note-se que o "Faleiros" traz mais uma referência ao Buriti Grande, pelo aspecto visual da palmeira enquanto falo, ("mas a pura luz de maio fá-lo maior" B, 126) a estender sua sombra sobre o terreno. Ao mesmo tempo, para Maria Behú "ele é que nem uma igreja" $(\mathrm{B}, 126)$, enquanto para Dona-Dona o Buriti Grande "parece até uma palmeira do capeta" $(\mathrm{B}, 106)$.

Esta palmeira/totem, como se vê, de acordo com a perspectiva de cada personagem, assume diferentes facetas, sendo possível falar de uma coexistência de valorações opostas, antitéticas, num mesmo signo, ressaltando-se, por exemplo, a união

\footnotetext{
${ }^{27}$ Nunca é demais lembrar o que a estudiosa Cleusa Passos já assinalou sobre a relação do nome deste personagem com o nome científico do buriti (Mauritia Vinífera) e de sua mulher iá Vininha.
} 
dos polos sagrado e profano, do carnal e do espiritual, todas amalgamadas poeticamente pelo autor.

Dizer deste clã que aqui se estabelece como descendente do buriti é ligá-lo a um elemento "plurissignificante", como foi dito em relação ao Éden por Haroldo de Campos. A palmeira que nomeia a narrativa traz em sua constituição dentro da obra de Rosa nada menos que a complexidade deste fenômeno humano que é o Amor, tratado nas linhas de "Buriti”. Belo, terrível, traiçoeiro, tranquilo, tumultuoso, carnal, espiritual, sagrado, profano. Facilmente poderia se fazer do buriti um redemoinho, que tudo transporta, fazendo girar até a perda total das referências, as certezas que se quer - ou se pretende - estabelecer sobre o Amor.

Se em "Buriti" o aspecto totêmico da palmeira é contundente, o mesmo não aparece, ou, ao menos não aparece da mesma forma, em "Campo Geral" no tocante ao mutum.

\subsection{2 - O pássaro}

Vale aqui retomar, por força de argumentação, o que se analisou sobre a relevância mítica desta ave noturna, também ligada ao amor por sua presença nas histórias indígenas mencionadas no capítulo anterior. Protetor da noite, ligada à possibilidade do encontro amoroso, ainda que denotando o lado negativo desta união, não é de se estranhar que Miguel traga em si o lado melancólico associado a tudo que pode vir com o amor e acabar de forma trágica.

Já no primeiro encontro com Maria da Glória, no serão que antecede sua partida, Miguel expõe parte de sua bagagem afetiva ao falar de seu passado, rememorando a afeição e o luto pelo irmão morto: “... Até hoje, não posso demorar o pensamento nele. Tenho medo de sofrer. Você acha que sou fraco?" (B, 89, grifo nosso)

Sem dúvida, das emanações de sua infância passada no Mutum, o medo é das mais expressivas, significante presente em muitas passagens de "Buriti" sempre próximas à perspectiva de Miguel: "Como a infância ou a velhice - tão pegadas a um país de medo. Miguel, sem o saber, sentia afastadas coisas, que se ocultavam de seu próprio pensamento" (B, 83, grifo nosso) O medo da mata, da noite, do sofrimento, da 
repetição, da morte, signos da negatividade radical que compõem a trajetória de Miguilim a Miguel.

O historiador francês Jean Delumeau (2009, p. 23/24), em seu estudo História do medo no Ocidente, estabelece a questão do medo à precoce consciência da finitude que caracteriza o ser humano. "O animal não tem ciência de sua finitude. O homem, ao contrário, sabe - muito cedo - que morrerá.” Prossegue este autor reforçando a ideia de que o medo, ao mesmo tempo em que se constitui como uma "defesa essencial que garante a integridade do ser, pode, no extremo, causar verdadeira chaga: "Pode-se morrer de medo, ou ao menos ficar paralisado por ele".

Logo se vê que o diálogo encenado neste serão é como um desafio ao homem Miguel, para saber se prevalecerá o arcabouço de medos que ele traz junto de si ou se, num movimento análogo ao que o levou para fora do Mutum em direção à vida adulta, ele irá ao encontro de seu "destino verdadeiro", de sua realização amorosa.

Note-se, também, que Miguel, embora traga a marca do medo em sua constituição subjetiva, deixa o Mutum ainda menino, movido por uma coragem inaudita. Este é um fato significativo a ser assinalado, pois ao mesmo tempo em que é descendente do mutum/Crax/Caz, é fato de que ele tem influências distintas por crescer e tornar-se adulto alhures, sem, aparentemente, nunca ter retornado ao sítio no qual viveu parte de sua infância. Desta forma, abre-se a perspectiva de diferentes experiências, dado o alargamento de seu horizonte pessoal. Deixa de ser Miguilim, ao sair de "Campo Geral" para tornar-se Miguel em "Buriti".

Seu caminho é, portanto, o de um verdadeiro migrante, quase um expatriado, que deixa sua terra natal para seus anos de formação intelectual - do qual pouco se sabe além do fato de ser veterinário - e afetiva - da qual nada se sabe - no ponto de encontro no final/recomeço do ciclo de Corpo de baile que é "Buriti". Se o medo é parcela importante de sua constituição subjetiva, faz-se indispensável o registro de sua coragem ao se deparar com Maria da Glória, força que o motiva a retornar ao Buriti Bom com a intenção de desposá-la, deixando o medo em suspenso.

Neste aspecto - o da saída do núcleo familiar - a trajetória de Miguel diferenciase daquela apresentada por Maria da Glória. Esta, mesmo tendo estudado em colégio 
interno na cidade grande, volta ao mesmo Buriti Bom, ao lugar de origem, mostrando-se aí sua forte vinculação afetiva e familiar com a terra. "Você é o Buriti Bom" (B, 160), observa Lalinha a Maria da Glória.

Obviamente que se poderia argumentar, em relação às trajetórias individuais de cada personagem, sobre as diferenças inerentes ao gênero de cada um deles e o papel que cabe ao homem e à mulher no contexto da sociedade patriarcal brasileira. Ao homem, relativa liberdade e autonomia para sair de casa e ganhar o mundo, enquanto à mulher cabe, eventualmente, a possibilidade de estudar, mas torna à casa paterna para sair, preferencialmente, quando se casa. Isto sem mencionar a diferença na condição social das duas famílias: uma abastada, no caso de Maria da Glória, e outra paupérrima, no caso de Miguel.

Sem prejuízo desta observação, cabe aqui ressaltar a dinâmica estabelecida entre a ligação das personagens à terra e aos elementos míticos que se relacionam com os clãs aos quais se ligam. A mobilidade da ave mítica garante, em parte, a errância de Miguel, incluindo aqui tanto sua partida do Mutum quanto o retorno ao sertão para o encontro com Maria da Glória, tanto o primeiro - obra do acaso - quanto o segundo - por vontade própria, movido por seu amor e intenção de desposá-la.

Quanto a Maria da Glória - e aqui se resgatam as metáforas florais afeitas à jovem: nascida do cacho do buriti mais altaneiro ( $\mathrm{B}, 90)$, fruta em ponto de ser provada, "no ponto justo, escorrendo caldo" (B, 94) - garante-se certa estaticidade ligada ao status vegetal do buriti.

Pode-se afirmar, na verdade, aliando a leitura mítica com a sociológica, que a mobilidade do mutum metaforiza a mobilidade guardada ao homem (Miguel) enquanto a condição de flor em vaso, esperando ser colhida, afina-se com o esperado em relação à mulher (Maria da Glória). Mas isto também mostra sua limitação, quando se lembra que a filha de iô Liodoro toma a iniciativa - deixando de lado a expectativa social em relação à sua atitude passiva - tanto na abordagem com Miguel, ao perguntar-lhe sobre sua possível namorada ou noiva, quanto na decisão de perder sua virgindade com Gualberto. 
Ressalta-se, desta forma, a força da ligação da personagem feminina à índole familiar expressa em Liodoro, de sua ligação ao buriti como totem ligado à fertilidade e ao encontro erótico. Esta atividade, busca da satisfação, comum entre pai e filha, pode ser entendida pela metaforização de outro ente da natureza, caçador por excelência, elencado para a caracterização destas personagens: a onça.

Para Liodoro se lê: "Seu conspeito era um acaso de firmeza mansa e onça, uma demasia sã em si, que minava da pessoa e marameava, revertendo na gente uma circunstância." (B, 95, grifo meu). Para Maria da Glória, "Glória: o olhar dado brilhante, sempre o sem-disfarce do sorriso como se abre, as descidas do rosto se assinalando - uma onçazinha; assim tirando às feições do pai [...]” (B, 86, grifo meu).

O casamento entrevisto de Miguel e Maria da Glória, por sua vez, tem a função de apontar para uma saída possível para a questão colocada das ligações afetivas e eróticas carregadas de aspectos incestuosos e adúlteros encontradas em "Campo geral" e "Buriti".

Luiz Roncari (2013, p. 83) em seu recente estudo sobre "Buriti" observa que, no encontro de Miguel e Maria da Glória, ambos omitem detalhes a respeito de suas origens, mais especificamente sobre a figura materna, frisando, no caso de Maria da Glória, a figura masculina, ainda que num tom figurado: o surubim, na fala de Glória e um "buriti altaneiro" na de Miguel. A herança de uma sexualidade mais abundantemente vivenciada é marca da família de Liodoro Maurício Faleiros, como lembra o mesmo Roncari (Idem, p. 48 e seguintes), quando faz um levantamento dos familiares ascendentes e relativos neste mesmo estudo.

Na caracterização de Nhanina, figura chave para entender parte da ética amorosa de Miguel, percebe-se a marca, por sua união com nhô Bernardo Caz, da infelicidade na busca amorosa que leva ao final trágico.

O que falta assinalar é que, no passeio noturno empreendido pela mãe de Miguilim e seus filhos, logo de saída o narrador observa.

Então, aquela noite, sem Pai nem Vovó Izidra, foi o dia mais bonito de todos, tinha lua-cheia, e de noitinha Mãe disse que todos iam executar um passeio, até onde se quisesse, se 
entendesse. Eta, fomos subindo, para lá dos coqueiros. (CG, $65-$ grifos meus)

Quando chegaram nos coqueiros, mãe falou que gostava deles, porque não eram árvores do Gerais: o primeiro dono que fez a casa tinha plantado aqueles, porque também dizia que queria ali outros coqueiros altos, mas que não fossem buritis. Mas o buriti era tão exato de bonito! (CG, 66/67 - grifos meus)

O amado buriti não encontra simpatia na perspectiva de Nhanina. Sua predileção recai sobre os coqueiros exóticos que, como ela, não pertencem aos Gerais. Trazidos por mãos alheias, são plantados no sertão para fazer valer a vontade do "primeiro dono que fez a casa" na qual, naquele momento, mora a família de Miguilim. Os altos coqueiros tornam a paisagem outra, e é com estes "outros" que Nhanina se identifica. Desagradalhe, aparentemente, tudo o que é dos Gerais, a começar pelo buriti. Embora se possa supor que ela tenha nascido naquela região, o fato é que se registra sua sensação de que aquele não é um lugar de pertencimento.

As características que são enaltecidas nas terras do Buriti Bom, a saber, a abundância de águas e os longos meses chuvosos, são estes que compõem o desagrado da mãe de Miguilim em relação ao Mutum: "lá chove sempre" (CG, 5). Ao fim e ao cabo, Nhanina se parece mais com Lalinha do que Maria da Glória - o que também já foi observado por Roncari - uma vez que, para além da semelhança física, são análogas a flores enxertadas, que não pertencem aos Gerais e não compartilham, em grande medida, com os termos de sua ética.

Se Miguel sente orgulho de sua descendência sertaneja, o mesmo não se pode dizer de sua mãe, ao menos pelo que se depreende do narrado: "Mas sua mãe, que era linda e com cabelos pretos e compridos, se doía de tristeza de ter de viver ali (no Mutum). Queixava-se, principalmente nos demorados meses chuvosos, quando carregava o tempo, tudo tão sozinho, tão escuro, o ar ali era mais escuro [...]" (CG, 5 grifos meus)

O negror da plumagem do mutum, Crax, se por um lado traz a associação com a noite e garante a beleza do animal, indica também, no tocante aos habitantes do Mutum, os Caz, certo aprisionamento e falta de perspectiva. Tanto pelo aspecto da má sina 
amorosa - afeito no conto e também no mito colhido por Barbosa Rodrigues ${ }^{28}$ - quanto na condição social e material da família de Miguilim, percebe-se horizonte negro, fechado, restrito, oposto ao verdor carregado de fertilidade e esperança dos habitantes do Buriti Bom, sob a égide da palmeira descomunal.

Em especial, pode-se ver, na perspectiva de Nhanina - que tinha "cabelos pretos" - o escuro das penas do mutum se refletindo, ou se estendendo, para o horizonte que escurece devido às chuvas, reforçando a sensação de solidão e opressão vivenciada no casamento e a ausência de alternativas para sua própria existência.

Ser membro do clã Caz/Crax mostra-se, para ela que faz parte da família mediante a contração dos laços matrimoniais, desde logo, evento agoureiro. Resta-lhe entregar-se aos amores claramente clandestinos - como com o Tio Terêz, irmão de seu marido - semelhantes àqueles que, na escuridão propícia do mito, regiam os encontros entre os irmãos.

\section{3 - Totem: antepassado mítico e atualidade paterna.}

“[...]o pai no lugar do animal totêmico. [...] Os primitivos mesmo declaram isso, e, onde o sistema totêmico ainda se acha em vigor, designam o totem como seu ancestral e pai primevo." (FREUD, 1912/2012, p. 202)

Ao usar aqui a noção de totem em relação a "Buriti" e "Campo geral" como instrumento de análise e interpretação, delimitaram-se, acima, certos aspectos relativos ao conceito de totem, de acordo com a definição de Lévi-Strauss. De forma semelhante, é indispensável trabalhar com a contribuição de Freud sobre o assunto, resgatando seu clássico texto Totem e tabu, de $1912 .^{29}$

Sem pretender aqui uma exposição exaustiva do pensamento freudiano, resta trazer alguns pontos principais, auxiliares no desenvolvimento da presente argumentação.

É conhecida a formulação do mito freudiano que, para o psicanalista, ensejou uma reflexão sobre as origens da cultura e sua relação com o fenômeno do totemismo.

\footnotetext{
${ }^{28}$ Vide o item 2.5 do capítulo 2.

${ }^{29}$ Na biblioteca pessoal de Guimarães Rosa, hoje no IEB, encontra-se um exemplar, em francês, deste volume de Freud, com algumas marcações na lateral do texto.
} 
O levante dos irmãos que se revoltaram contra o pai da horda primeva - violento senhor absoluto das mulheres do bando - sua morte, devoração e posterior passagem à condição de totem protetor do clã indicam, no nível social, a passagem da selvageria ao estado da cultura, pela instituição da proibição do incesto e o estabelecimento da exogamia como corolário do totemismo.

No comentário de Caterina Koltai (2010, p. 46), o mito da horda primeva criado por Freud e as consequências decorrentes desta tese apontam para a passagem de um "estado arcaico, no qual reinavam incesto e violência, para desembocar num outro regido por um contrato social, no qual tanto o incesto quanto o monopólio da violência eram proibidos".

O nascimento deste contrato social, em termos individuais, será conhecido, na teoria psicanalítica, como a instância psíquica do superego, internalização dos ditames sociais e, ao mesmo tempo, precipitado de identificações resultantes da dissolução do Complexo de Édipo.

É possível notar, na fatura literária de "Buriti”, certos pontos de comunicação com as formulações freudianas, principalmente quando se pensa nas ações de iô Liodoro frente ao seu núcleo familiar e em suas "mulheres exatas". Em certa medida, o patriarca se aproxima da figura do pai primevo, tendo em vista sua centralização na relação com as mulheres, sua exclusividade no trato com estas, bem como o afastamento relativo dos filhos do sexo masculino.

No confronto com esta autoridade absoluta, e garantindo, relativamente, a mudança na economia erótica do patriarca, mas também de outros membros do clã - se pensarmos em sua relação com Maria da Glória - Lalinha representa aqui a possibilidade de um "contrato social" outro que não o do erotismo natural, exposto no capítulo 1. A evolução, por assim dizer, deste clã fechado em si mesmo para um estágio no qual pode haver uma maior influência do elemento humano - por intermédio de um ritual de culto à Beleza, se dá, nas páginas de "Buriti”, pela ação deste ente da cidade, esta "planta andrógina" $"$, pronta a confrontar a égide do erotismo natural inspirado pelo Buriti Grande à lógica do desejo humano.

\footnotetext{
${ }^{30}$ A expressão é de Ana Maria Machado.
} 
Não se deve esquecer ainda, mesmo que sem tanta ênfase, a influência indireta do representante paterno de Miguel/Miguilim. É fato que a aproximação de Miguel do Buriti Bom tem efeito decisivo, na medida em que é o disparador de uma série de eventos na trama. Mas também é certo que, do ponto de vista erótico, sua contribuição é ainda tímida, "tristonha", para lembrar a percepção de Gualberto sobre o rapaz. Parte desta presença, certeira ainda que contida, pode ser entendida quando se pensa, em perspectiva, a relação de Miguilim com nhô Bernardo Caz, soturno e violento descendente do mutum, Crax, "crasso".

\subsection{1 - Liodoro: árvore}

"ele era meio dos Gerais e dali - de seus matos, seus campos, feito uma árvore".(B, 228)

"Modo estranho, em iô Liodoro, grande, era que ele não mostrava de si senão a forma. Força cabida, como a de uma árvore".(B, 132)

Tendo sempre em mente o parecer crítico de Gunter Lorenz sobre Corpo de baile, já exposto no Capítulo 1: "o sertão [...] do Brasil, um mundo no dia da Criação, povoado por homens que ainda não perceberam as consequências do pecado original, que ainda não derrubaram as pontes para o paraíso" (LORENZ, apud ROSA, 2003, p. 377.), tem-se aqui a possibilidade de incrementar a discussão sobre o elemento de passagem, ponte, transição que caracteriza a trama de "Buriti".

Isto porque, embora haja inegável aparência de um núcleo social civilizadamente constituído, o proceder de iô Liodoro enseja uma profunda reflexão, na qual tanto podem caber a atualidade histórica da sociedade patriarcal brasileira quanto certos traços de uma antiguidade mítica trazida pelo mito da horda primeva, de Freud. Em certa medida a violência contra o sujeito da sociedade brasileira recria parte desta antiguidade mítica. Em "Buriti" mostra-se um caráter permissivo a certas manifestações de incesto - como no caso já mencionado de sua relação com Lalinha - e uma dose de violência discreta e silenciosa, atrelada, certamente, mais à posse das terras e à abastança monetária que à força bruta, esta mais afeita ao mito freudiano, sem a mediação de forças institucionais.

Por sua densidade na caracterização desta personagem, vale reproduzir este trecho de "Buriti", ainda que um tanto extenso: 
[...] Temiam iô Liodoro? Tem um não em todo sim, e as pessoas são muito variadas. Aí em algumas horas, temessem. Mas não precisavam de dar demonstração. Tinham respeito.

Iô Liodoro era um homem punindo pelos bons costumes, com virtude estabelecida, mais forte que uma lei, na sisudez dos antigos. Somente que o amor dele pela família, pelos seus, era uma adoração, era vasteza. Via disso, de certo, que não queria se casar outra vez, depois de tanto que enviuvara. E ele, por natureza, bem que carecia, mais que o comum dos outros, de reservar mulher. Mas prezava o inteiro estatuto de sua casa, como que não aceitando nem a ordem renovada, que para ele já podia parecer desordem. (B, 95, grifos meus)

Trata-se de um dos trechos em que a narração se cola à perspectiva de nhô Gualberto Gaspar, compadre do patriarca, que não deixa de expressar sua opinião enviesada, plena de inveja em relação ao vizinho. Ainda assim, avaliar esta impressão subjetiva em relação a Liodoro não deixa de trazer subsídios significativos para o presente estudo.

Note-se a ambiguidade, por exemplo, ao falar dos "bons costumes" sem que se esclareça quais são eles. A violência vai implícita na autoridade que emana do patriarca em relação aos demais moradores da região, no temor disfarçado de respeito, e na conotação sempre violenta do verbo "punir" na frase de efeito suficientemente vazia a ponto de tudo nela caber: "punindo pelos bons costumes". Louva-se, por outro lado, a "virtude estabelecida, mais forte que uma lei".

Ora, pode-se cogitar que este personagem, Liodoro, que "por natureza", reserva mulheres como quem estoca mantimentos faça do seu desejo a lei, estando aí, quem sabe, sua "virtude", que pode ser mais forte que "uma lei" "dos antigos", uma antiga lei, quiçá esta lei totêmica, mítica. Iô Liodoro, desautorizando qualquer lei que não seja seu desejo, emanação natural da força da terra, autoriza-se a manter para si "mulheres exatas", expulsando os filhos Ísio e Irvino e mantendo sob sua vigilância Maria da Glória e Behú. O “desfrute” - e o uso do verbo afeito a um elemento vegetal não vai ao acaso - em relação às filhas mulheres não se dá, como no mito freudiano, no plano sexual, mas no controle de mantê-las junto a si, sob sua tutela, na Casa, junto com outro séquito feminino: as mulheres da cozinha. 
Guiado por esta antiga lei, que só enxerga sua própria satisfação, concretização bruta do impulso erótico - antiguidade mítica que se reatualiza no contexto histórico deste sertão brasileiro - Liodoro estabelece seu "estatuto": "conjunto de regras de organização e funcionamento de uma coletividade, instituição, [...] pública ou privada" (HOUAISS, 2001, p. 1248). Tal estatuto, observa o narrador, era prezado por inteiro, não sendo aceito "nem a ordem renovada, que para ele já podia parecer desordem".

Outras passagens reafirmam esta condição de iô Liodoro que vive esta dupla e curiosa intersecção de um passado mítico - de uma imemorial antiguidade pré-contrato social - mas, ao mesmo tempo, pleno de significação no contexto social brasileiro. Pode-se pensar, talvez com mais precisão, o quanto a organização social brasileira, percebida e transmutada por Rosa em sua ficção, propicia a manifestação de certas pulsões afeitas a este passado - histórico e pessoal - com desconcertante legitimidade. Em nome do interesse e satisfação pessoal de um "chefe de família", suspende-se, em favor deste, todo e qualquer contrato social.

De novo, quem observa é Gualberto: "O que Liodoro é, é antigo. Lei dum dom, pelos costumes. E ele tem mesmo mais força no corpo, açoite de viver, muito mais do que o regular da gente. [...]fraqueza dele é as mulheres...” (B, 104, grifo meu).

Note-se a insistência nos termos jurídicos, tanto aqui como no trecho acima, como "lei" e "estatuto", além da menção, mais uma vez, aos "costumes", associados por contiguidade às mulheres, fraqueza que faz manifestar a "força macha" do personagem. Ou, na percepção do Chefe Zequiel, dirigindo-se a Miguel e Gualberto enquanto apontava para Liodoro: “- "Duro, duro...” Fazia um gesto de sacudir mão, de sova bem dada, e ele mesmo dizia e se respondia: - "Duro, duro?” - Dém-dém!” O que podia não ter significação.” (B, 130)

A significação, que "podia" ser vazia, é, na realidade, plena, sobretudo na evocação dos "costumes" afeitos ao Brasil, seja no exercício da violência seja no arraigado costume da disposição das mulheres à serviço da satisfação sexual masculina. Antonio Candido (1951, p. 300) ao estudar a família brasileira lembra que, na sua origem, a família colonial no Brasil tinha uma função mais política e econômica do que propriamente afetiva e sexual, sendo "natural" a existência de prostíbulos ou outros 
arranjos locais para dar conta da demanda de satisfação que, no seio da família, ficava em segundo plano.

Os filhos "expulsos", por seu turno, dão ao pai "um meio desgosto". Mas herdam certo traço, assim como Maria da Glória, na medida que não se conformam com o matrimônio tradicional que se esperaria de uma tradicional família abastada do sertão mineiro. Ísio se casa com uma ex-prostituta e "vive em anjos" em propriedade vizinha à do pai. Irvino, "que detestava a roça" (B, 149), deixa a esposa na cidade sem mais explicação para ficar com outra, "uma morena mandadora" (como Liodoro?), “corpulenta, a voz de homem" (igual à do pai?). (B, 147, grifos meus)

As aspas aplicadas à indicação do distanciamento dos filhos homens fazem-se necessárias, uma vez que não se trata da força bruta do pai que se impõe aos filhos - até porque não se trata de um decalque, efeito de pura e simples sobreposição do mito freudiano ao texto de Rosa. Mas é digno de nota perceber no cenário do Buriti Bom a gravitação dos entes femininos em torno do único homem da casa, o patriarca Liodoro.

Note-se, por isso mesmo, que a questão da afetividade paterna em relação aos filhos, é dada como certa em mais de uma passagem. Do trecho citado mais acima, temse que: "Somente que o amor dele pela família, pelos seus, era uma adoração, era vasteza." Mais adiante, o mesmo Gualberto observa: "Iô Liodoro é pai amoroso, como não pareça" (B, 103). Miguel, por sua vez, observa que ele é "mudamente afável" (B, 130).

Pensando no contexto específico da família brasileira, como já foi feito acima, Antonio Candido (Op. Cit. p. 303) assinala as mudanças pelas quais esta vai passando ao longo da história, em seu estudo "The brazilian family". No que se refere ao quadro apresentado em "Buriti", é nítido perceber, correlacionando o texto ficcional com o estudo sociológico, a função social da família não mais atrelada à perspectiva exclusivamente econômica e política encontrada desde os tempos da Colônia. Aqui se vê a marca da passagem para uma família que é, também, um sistema afetivo e sexual, mais afeita ao sistema burguês, citadino, ainda que com as marcas deste passado mais tradicional. 
Outra marca desta transformação no quadro da família brasileira assinalada por Candido é o arrefecimento das lutas de sangue, até a morte, entre outros motivos, pela disputa das mulheres: "the disappearance of blood feuds and conflicts between families is an evident sign of the disintegration of the colletive consciousness of kinship in favor of a restricted domestic organization [...]” (Idem, p. 309).

Nhô Gualberto comenta, em tom quase sociológico, o tranquilo passeio de iô Liodoro e Dionéia, mulher do Inspetor, enquanto este procura no meio da lama pelo capinzinho que poderia restituir-lhe "as forças machas desabrocháveis já perdidas": "Em outros tempos, homem matava homem, por causa de mulher! Como os bichos fazem... Mas o mundo vai demudando. Raça de gente vai esfriando, o tempo será se vai ficar todos frios, feito os peixes.” $(\mathrm{B}, 112)$

Mais uma vez a evocação da força do elemento vegetal - já estudada no primeiro capítulo - portador de um milagroso poder capaz de restaurar a potência sexual masculina. A impotência do Inspetor, pode-se afirmar, vai, ao que tudo indica, muito além da questão sexual, sendo visível a instalação de outra ordem no lugar daquela desaparecida e lamentada no comentário de Gualberto. Não há mais a matança dos machos entre si, seja pela disputa das fêmeas ou pela vingança das honras manchadas. Há, agora, a relação de submissão do agregado perante o dono das terras.

Parece evidente aqui a evocação daquilo que se chamavam "crimes passionais em defesa da honra", segundo Marilena Chauí (1984, p. 78), para se referir aos crimes cometidos pelos maridos traídos, que lhes garantia a absolvição pelos assassinatos caso se comprovasse o adultério feminino. A cena analisada expõe a contradição inerente a esta prerrogativa injusta, pois delata a relação assimétrica de um serviçal que tem a mulher amasiada do chefe das terras. Mais decisivo que ter a honra manchada é a obediência que se deve a este que, em boa medida, garante a integridade física e o sustento do casal Inspetor/Dionéia.

A submissão se dá também pelo contraste dos elementos que compõem a cena. Esta ocorre aos pés do Buriti Grande, em época de chuva, com o chão todo encharcado. Convidado pelo Inspetor a procurar o capim milagroso, Gualberto, "sem soberba", se recusa: "O Inspetor desceu do animal, se curvou, chega se ajoelhou, nas umidades. [...] 
Estava jazente aí, de mãos no chão, catando, o Inspetor anda sempre vestido de preto: figurava um besouro bosteiro..." $(\mathrm{B}, 112)$

Curvado no chão úmido, de preto, o besouro - animal de sangue frio, como o peixe - humilha-se na tentativa de recuperar pela crendice popular o que se perdera: além da potência, a dignidade. Ao rés do chão, ajoelhado "debaixo do pé do buritigrande", o Inspetor contrasta com o chefe do clã do Buriti, Liodoro e Dionéia, altaneiramente montados, sem fazer menção de apearem do cavalo: "parece que nem se importavam”. (B, 113)

A autoridade do senhor da terra sobre seu serviçal se superpõe à superioridade da silhueta do buriti sobre o "capinzinho" e à posição inferior do Inspetor/besouro bosteiro ante os cavalos montados por Liodoro e Dioneia. Retomando a esfera da influência do elemento vegetal a compor a força do totem buriti, lembre-se que Dioneia é uma espécie de planta carnívora, também conhecida como Vênus papa-mosca que digere pequenos insetos (como o besouro) e vive em pântanos. Aqui, "à sombra" do Buriti/Liodoro.

No trânsito entre a antiguidade mítica e a atualidade histórica, ou melhor, na convivência possível entre estas duas esferas no texto de Rosa, outra relação entre "Buriti" e o Totem e tabu de Freud é o desejo de Maria da Glória de saber o nome da “outra”, que roubou o marido de Lalinha, a fim de lhe encomendar um feitiço, logo após a visita de Dô-Nhã. Trata-se de uma evocação de um passado longínquo ainda vivo em certas práticas, como que resistindo ao passar do tempo: "Mas, ali no sertão, atribuíam valor aos nomes, o nome se repassava do espírito e do destino da pessoa, por meio do nome produziam sortilégios." (B, 170)

A evocação das práticas dos diversos povos arroladas por Freud traz em destaque o tabu de se pronunciar o nome dos mortos, assim como a questão da nomeação dos clãs totêmicos. Freud (1912/2012, p. 96) escreve: "para os selvagens o nome é o elemento essencial e patrimônio importante da personalidade, que eles atribuem à palavra o pleno sentido de coisa”. Mais adiante, ao falar da nomeação dos clãs em referência aos totens, o psicanalista pontua (Idem, p. 173): "Para os primitivos, como para os selvagens de hoje e mesmo para nossas crianças, os nomes não são algo 
indiferente e convencional [...] mas algo essencial e pleno de sentido. O nome de alguém é parte importante de sua pessoa, talvez de sua alma”.

Note-se semelhança entre os "selvagens" de Freud e este filhos da selva/sertão que são os habitantes do Buriti Bom. A presença e mesmo a perseverança destas práticas ancestrais parecem ainda harmônicas - para não dizer naturais - a ponto de contar com a anuência da representante-mor do Catolicismo, Maria Behú: “[...] também Maria Behú de boa mente aceitara os ofícios da Dô-Nhã.” (B, 170)

Faça-se ainda uma observação sobre isto que parece óbvio: a sabedoria dos "selvagens" permanece viva, entre os estudiosos da língua e da literatura, por certo. Senão, parte preciosa de tudo que já se escreveu, sobre Rosa e todos os autores até hoje estudados pela Crítica, teriam de ser jogados fora. Não fosse a percepção, tão antiga quanto o Homem, do Nome enquanto receptáculo de sentidos e histórias, estaríamos ainda na Pré-história das ciências interpretativas. Se é legítimo falar, em relação à obra de Guimarães Rosa, da permanência do velho no novo, na modernidade com que trata a matéria prima ancestral do sertão e do sertanejo, parte disso se deve à profunda compreensão do poder da palavra - matéria prima da Literatura - que evoca, a todo instante, a aurora do Homem, quando o maravilhamento diante do mundo em descoberta pode ser posto em palavras.

\subsection{2 - Bernardo: a fúria}

Resta falar de Bernardo Caz, pai de Miguilim, chefe do clã do mutum. O contraste entre Bernardo e Liodoro, neste momento, será bastante produtivo em termos críticos, a começar pelo nome dos personagens. Bernardo, etimologicamente, o "urso" (Bern) "forte" (hart), faz ressoar a força bruta e o caráter pouco sociável do animal, quase como um sinônimo de isolamento. Liodoro, por sua vez, traz a marca dos "laços de ouro", sendo este preservador dos laços familiares, para o bem e para o mal, conforme já assinalado pela crítica ${ }^{31}$.

\footnotetext{
${ }^{31}$ A significação do nome de Liodoro, aqui, se afina com a proposta de Luiz Roncari (RONCARI, 2013, p. 46), sendo respaldada pela leitura de Ana Maria Machado em seu estudo sobre os nomes na obra de Guimarães Rosa, quando anota que Liodoro - Heliodoro, "sol de ouro", em torno do qual gravitam as demais personagens - figura, com sua autoridade, o "vínculo que liga os membros espalhados da família" (MACHADO, 1991, p. 84). Perspectiva diversa, mas não necessariamente excludente, ressaltando a virilidade, a força pulsional de Liodoro, é estabelecida por Adélia Bezerra de Meneses, ao ressaltar a
} 
Se, por contraste, as referências a iô Liodoro marcam a afetividade discreta, embora marcante, do patriarca, conforme as citações trazidas acima, a leitura de "Campo geral" caracteriza o pai do menino como figura de difícil trato, que não deixa de esconder sua dificuldade na relação com o pequeno Miguel.

“Mas não era o Pai quem mais primeiro tinha ódio dele Miguilim?” (CG, 83) Esta frase sintetiza a vivência do menino Miguilim que o adulto Miguel traz, ao menos em parte, como sua bagagem afetiva. Em meio à surra que recebe, sobrevém a ideia de matar o pai. Nada semelhante à experiência colocada nas linhas de "Buriti" em relação a iô Liodoro e o trato com seus filhos.

Já que se falou da questão do nome, vale notar a variação do nome desta personagem: Nhô Bernardo Caz, Béro, Pai. Por se tratar do uma narrativa cujo foco narrativo vem sempre muito próximo da perspectiva infantil, não deixa de ser previsível, e cheio de consequências, ter o "Pai", como personagem. A intenção não é fazer um levantamento de todas as consequências interpretativas deste fato, apenas marcar que, embora desde o princípio, Miguilim não quisesse "de forma nenhuma" proceder mal e desgostar o pai $(\mathrm{CG}, 6)$, o fato é que, talvez pela excessiva proximidade com a "Mãe" e sua sensibilidade exacerbada, revela-se, para o pequeno Miguel, a dimensão do "urso forte", Bernardo, Béro, fero, feroz.

Uma das queixas trazida pelo Pai - representante chefe do clã totêmico - é a sentença de que Miguilim não se afina totalmente ao grupo familiar: "Este menino é um mal-agradecido. Passeou, passeou, todos os dias esteve fora de cá, foi no Sucuriju, e, quando retorna, parece que nem tem estima por mim, não quer saber da gente..." (CG, 6 - grifos meus) Trata-se da primeira fala do Pai trazida em "Campo geral”, e a tônica não será muito diferente até o final da narrativa: "O que ele quer é sempre ser mais do que nós, é um menino que despreza os outros e se dá muitos penachos. Mais bem que já tem prazo para ajudar em coisa que sirva, e calejar os dedos, endurecer o casco na sola dos pés, engrossar esse corpo!" (CG, 82 - grifos meus)

\footnotetext{
"força do leão, que ecoa em Leo-doro" (MENESES, 2010, p. 126). Esta autora ainda aponta para o caráter "leonino e solar" do patriarca, aproximando-se, relativamente, ao estudo de Ana Maria Machado citado aqui.
} 
Fica marcada nas falas paternas a percepção que este tem do filho, como alguém que quer ser diferente dos demais membros do clã. Quase em tom de inveja ou ciúme o Pai marca o fato dele ter passeado e sido crismado no Sucuriju, lugar com nome de cobra. Índice de traição?

Já foi mencionado no capitulo 2 o valor da crisma como cerimônia para confirmação do nome de batismo e, portanto, de pertencimento ao grupo familiar. Certamente que a expectativa de Nhô Bernardo era outra quando do retorno de Miguilim ao Mutum, talvez um ato de agradecimento, demonstração de "estima", que viesse lhe tomar a bênção, algo que assinalasse que o menino quisesse "saber da gente".

Na percepção de Pai, no entanto, Miguilim, embora membro do clã, Caz/Crax, "quer é sempre ser mais do que nós". Freud já assinalara em Totem e tabu a importância dos filhos nas sociedades patriarcais, principalmente quando do desenvolvimento da agricultura. Por certo que a questão aqui vai nesta direção, bastando lembrar a própria condição de arrendatários da família de Nhô Bernardo e as diversas alusões ao trabalho com a terra, destino que o Pai vê como natural do filho.

Por diversas razões, que não caberiam analisar aqui, visto que excederia à proposta do estudo, Miguilim destoa do grupo. Pai insiste em fazer valer sua autoridade, mediante os castigos e o processo de educação pelo trabalho, insistindo no endurecimento necessário à vida na roça (a escolha dos verbos é autoexplicativa: “ajudar”, “calejar", “endurecer”, “engrossar”) e no pertencimento ao clã.

Por mais que o viés das falas paternas possa vir carregado de um ódio em relação ao filho, não deixa de ser relevante a frase: "é um menino que despreza os outros e se dá muitos penachos." Talvez mais penachos que um mutum Caz normalmente deveria ter. Talvez mais próximo do ancestral totêmico Crax, no ponto de alçar voo além daqueles que Miguilim já alçava pela imaginação e voar para fora do Mutum, lembrando que este comentário do Pai vem pouco antes do fim da narrativa. $\mathrm{O}$ penacho, por sua vez, é justamente a crista, e por extensão, representa o mando, o governo de si, que, no caso, entra em confronto com a autoridade paterna.

Como se não bastasse toda a sorte de violências físicas e verbais trazidas ao longo do conto, Miguilim testemunha, como se sabe, a tumultuosa questão amorosa dos 
pais, que se encerra de forma trágica com o suicídio de Nhô Bernardo. Já se disse aqui o quanto este traço "bem herdado" influencia, relativamente, a aproximação de Miguel ante o Buriti Bom, sobretudo com Maria da Glória. Vencer o "país de medo", tarefa que Miguilim já enfrentara no obscuro Mutum, se colocará novamente ante a amplitude solar do "Buriti".

Cabe assinalar que Miguel/Miguilim acaba por realizar parte do desejo materno, de ir além do "morro" que a impedia de ver "outras coisas, que o morro está tapando de mim" (CG, 6) A mesma Nhanina que expressara desde sempre seu descontentamento em relação ao Mutum, na sua tortuosa busca pela felicidade afetiva, passa ao filho parte de sua sina. O pertencimento ao clã do mutum, no seu aspecto mais taciturno e sombrio, como se vê, não é absoluto no caso de Miguel, abrindo-se a possibilidade de "em alegria, no mato" a ave mítica "dançar de baile", prenunciando outro desfecho que não o trágico.

\section{4 - O desejo por totem: Lalinha}

"somente uma coisinha desejada" (B, 200)

Resta observar mais atentamente um elemento absolutamente estranho a todo este contexto envolvendo o regime totêmico dos clãs que se encontram em "Buriti". Estranho, e, no entanto, participante ativo da trama e decisivo para a mudança no quadro geral da narrativa.

Lalinha, outra fêmea trazida ao Buriti Bom sob nobre pretexto, acabará se mostrando como uma inesperada "desordem" na estaticidade mítica do funcionamento dos habitantes da localidade. Tendo toda a segunda parte da novela dedicada à perspectiva desta personagem, o efeito de estranhamento em relação àquilo que parece natural aos moradores do lugar e seu posterior envolvimento com Maria da Glória e Liodoro levarão a uma mudança significativa na novela.

Isto se dará justamente na medida em que, através de sua ação, as "leis" e "estatutos" que regem este mítico "belo poço parado" sejam questionados e se abram ao fluir do tempo histórico, às demandas do sujeito moderno, autônomo, que ela representa em contraste com o erotismo natural, que se manifesta através das personagens "da terra". 
Alguns trechos reforçam a ideia deste conflito entre a dificuldade da fruição do tempo para os moradores do Buriti Bom, de acordo com a perspectiva de Lalinha:

Tudo ali podia repetir-se, mais ralo, mais lento, milhões de vezes, a gente sufocava por horizonte físico. $(\mathrm{B}, 164)$

Novo dia. Tudo invariável. Todos tão em mesmo, até Maria da Glória; então não notavam o tempo? [...] depressa eles se refugiavam no uso, ramerravam, a lidada miudez da vida retomava-lhes o ser. $(\mathrm{B}, 230)$.

$\mathrm{Ou}$, de forma mais contundente, no trecho seguinte:

[...] aquilo era a Família. A roda travada, um hábito viscoso: cada um precisa de conter os outros, para que não fossem e vivessem. Um antigo amor, rasteiro.

Em certas noites, só, Lalinha retornava à tenção de partir, tomando-a um tédio de tudo ali, e daquela casa, que parecia impedir os movimentos do futuro. Do Buriti Bom, que se ancorava, recusando-se ao que deve vir. [...] Ali, nada se realizava, e era como se não pudesse manar - as pessoas envelheciam, malogradas, incompletas, como cravadas borboletas; todo desejo modorrava em semente, a gente se estragava, sem um principiar; num brejo. Não acontecia nada. Um dia, aconteceu. Chegara aquele moço, chamado Miguel, vindo da cidade. (B, 191, grifos meus em todas as citações)

Salta aos olhos a insistência no campo semântico da repetição, da invariância, da imobilidade que levam à morte do desejo. Não se trata apenas do contraste entre a vida na roça e o ritmo da cidade grande que Lalinha traz consigo, mas de uma percepção da personagem em relação àquele locus específico e as relações estabelecidas entre os habitantes da Casa (grafada muitas vezes em maiúsculo). Note-se que a recusa "ao que deve vir" é do Buriti Bom, como uma resistência arraigada à força da terra, do brejo, aqui assinalado em sua potência mortífera. Trata-se do embate entre o "hábito viscoso" e repetitivo disto que se apresenta como imutável e a perspectiva de uma personagem que, de passagem pelo sertão, busca seu caminho e põe em questão a lógica reinante no local, pondo em movimento, à sua maneira, as peças deste tabuleiro.

Não por acaso, nesta segunda parte, as marcações temporais mostram-se mais abundantes, oscilando entre o tempo dos trabalhos da roça e a pressa crescente de Lalinha em retornar à cidade. Assinalam-se os preparativos para a moagem da cana, as 
festas como o Carnaval, o São João e o Natal, o tempo das chuvas, sinais do tempo cíclico a se repetir indefinidamente.

O desafio do Buriti Bom "ao que deve vir", porém, acaba dando sinais de debilidade, sendo determinante o acaso e a força destes que estão distantes, navegando no curso da História. A começar por Lalinha, casada com o filho pródigo que não retorna à casa paterna, antes só se distancia mais e mais. Com o casamento desfeito, trazida ao sertão pelo sogro, Lalinha se alia a Maria da Glória e terá papel decisivo quando da vinda ao sertão - na realidade um retorno - do "moço da cidade", Miguel, outro acaso, como um sopro à superfície do "poço parado". Golpes decisivos a vencer a resistência do lugar, "destravando a roda", são a carta anunciando o nascimento do filho de Irvino e a morte de Behú. A vida, a morte, idas e vindas, movimento. Não há como negar a força do desejo, motor da História que atravessa esta "estória" e que, por ação dos "viajantes" - Miguel e Lalinha - se torna possível.

As marcas do erotismo natural, expostas no capítulo 1, ganham aqui, com a perspectiva de Lalinha, a possibilidade do contraste. Decisiva, portanto, é a menção ao desejo que, no contexto do Buriti Bom, parece destinado à morte, uma vez que, para Lalinha, o peso de uma âncora impede que a vida se abra ao "que deve vir" como sinal inevitável do tempo que urge e ronda o "poço parado". Por ação da nora de iô Liodoro, mais próximo ao desfecho da narrativa, esta estaticidade é posta em xeque, sendo agora presa por um tênue fio: “À noite, o Buriti Bom todo se balançasse, feito um malpreso barco, prestes a desamarrar-se, um fio o impedia. (B, 230, grifo meu)

É através de Lalinha, nesta versão moderna e brasileira do mito da horda primeva, que se estabelecerá o contrato social que regulamentará uma "ordem renovada" na erótica de "Buriti". Sua função será, essencialmente, a de mediadora, seja pela fantasia nas conversas com Maria da Glória, no jogo da bisca com iô Liodoro e, finalmente, nos serões eróticos com o sogro. A diferença essencial é que, contrariando o que Freud estabelece em Totem e tabu, a "consciência de culpa", inerente ao contrato social e ao estabelecimento do superego, não há em "Buriti", aparentemente, sinal de culpa no que diz respeito a esta "passagem". É fato de que não há assassinato, tampouco devoração do pai primevo que justifiquem o sentimento de culpa como no mito freudiano. Mas, no que diz respeito aos assuntos eróticos - e estes tocam diretamente o 
"pai da horda" Liodoro - de qualquer forma, a resolução dos conflitos se dá de forma relativamente livre e sem sinais de culpa ou sérios constrangimentos às personagens.

Seguindo a linha argumentativa desenvolvida neste capítulo, será necessário assinalar que Lalinha não é regida por totem qualquer, sendo, antes, sinal de um tipo relativamente estranho à ficção de Guimarães Rosa até o momento, uma mulher citadina, independente até certo ponto, de casamento desfeito. Diferente das personagens sertanejas, também ricas em nuances e contradições, mas "frutos" do meio criado por Rosa - o sertão ficcional - Lalinha representa esta ponte de comunicação entre mundos distantes, mas que, inevitavelmente, estabelecem comunicação cada vez mais intensa entre si na literatura do escritor mineiro, como se verá, por exemplo, em muitos contos de Primeiras estórias.

Para entender o contraste entre a presença de Lalinha sob o fundo do Buriti Bom, o estudo de Gerd Bornheim, "O sujeito e a norma”, traz elementos decisivos, por tratar justamente disto que parece distintivo em Lalinha, a saber, traços afeitos à autonomia do sujeito. Pondo em contraste a ascensão da burguesia com os valores da Idade Média, o autor caracteriza as transformações pelas quais passou a concepção de sujeito até os dias atuais.

Destacam-se aqui as noções de liberdade e conhecimento, decisivas para esta definição. Bornheim (1992, p. 250) retoma as transformações destes conceitos em perspectiva histórica, sublinhando a importância de pensadores como Francis Bacon e Descartes para a construção da concepção do "conhecimento como uma forma de poder" e a articulação desta com a ideia cartesiana de liberdade. Citando Bornheim (1992, p.251): "Descartes comete o feito de restringir a liberdade ao livre-arbítrio", sendo lícito afirmar que "o homem, pelo livre arbítrio, promove-se à condição de senhor - senhor de sua escolha.” Isto torna possível, de acordo com este autor, a concepção do sujeito moderno como uma realidade autônoma, independente.

O que se lê nos diversos momentos em que o foco narrativo é centrado na perspectiva de Lalinha é o embate de um sujeito em conflito consigo mesmo, na busca do conhecimento de si em direção à sua realização como sujeito autônomo. 
Ele ia ver. Gostaria de aparar-lhe o olhar atônito, seu pasmo de bárbaro. Ao mesmo tempo, provava-o. Se ainda a levava, se não a levava. [...] Saudou o espelho. - "Sabia de uma assim, meu caro iô Liodoro?..." (B, 150)

Tomavam-na a tento de um perseverar fiel, a despeito de tudo findo; e ela, a bem dizer, conservara-a (a aliança) apenas por petulância, e quase como um sinal de maior liberdade $(B, 155)$

Cada uma precisa de se sentir desejada... $(\mathrm{B}, 157)$

Agora, descobrira que tinha poros que ela mesma ignorara. (B, 160)

Lalinha traz em si o germe da reflexão, do conhecimento de si e da auto realização. Acede ao intento de Liodoro de ser levada ao Buriti Bom na possibilidade conservadora do retorno de Irvino e o consequente "salvamento" do matrimônio. No entanto, após a chegada de Miguel, "vindo da cidade" (B, 191), e a paixão de Maria da Glória pelo moço, observa-se ao longo da segunda parte o debater-se da personagem em torno da questão amorosa, mas, sobretudo, na busca de um conhecimento de si e da afirmação de sua autonomia.

Os trechos acima destacados dão uma ideia desta busca, na medida em que flagram diversos momentos da trajetória de Lalinha. O conhecimento de si própria toma dimensão privilegiada, seja para confrontar o sogro que a vem buscar, seja no contraste entre si e os outros da fazenda seja no nível do solilóquio. O caminho, como se sabe, levará tanto ao desejo em relação a Maria da Glória até o ritual noturno entre ela e Liodoro, culminando com a determinação por voltar à cidade, não sem antes por às claras o desejo do sogro por ela e sua disposição de finalmente "conhecê-la", expressão máxima de sua autonomia.

Após a proposta feita a Liodoro, evidencia-se, mais uma vez - e dessa vez de forma definitiva - sua condição de estrangeira em relação a este lugar "retirado de rota" e seus habitantes: "tudo era para mostrar, a ele, que ela já era mesmo uma estranha, uma mulher, prestes a deixá-los, sem perigo de comprometê-los, de contagiar o Buriti Bom com seu ser." (B, 243/244, grifo do autor)

A autonomia de Lalinha, sua coragem para seguir o percurso de seu desejo, seu esforço por sair da "roda travada" e seguir seu próprio caminho soam estranhos ao 
"poço parado" do Buriti Bom, a ponto de parecer nocivo e "contagiar" a pureza mítica, regida pelos ancestrais ciclos da Natureza encarnados no Buriti Grande, representante mor da condição do erotismo natural. Com a dissolução definitiva do casamento, materializada na carta que anuncia o nascimento do herdeiro legítimo do clã, desfaz-se o derradeiro dique. O incesto se desfaz e o intercurso com Liodoro não representa mais uma transgressão aos padrões do clã. Ela volta para a cidade, seu mundo próprio, e deixa o campo entregue às suas próprias leis, novamente fechadas ao elemento estranho, ex-cêntrico que ela até então representava. Uma vez agitadas, momentaneamente, as águas do "poço parado", sua imobilidade se repõe, tal e qual eram anteriormente.

Parece legítimo aliar às reflexões sobre a autonomia do sujeito segundo Bornheim a noção de desejo, nos moldes da teoria psicanalítica, como forma de compreender a trajetória de Lalinha em meio a este jardim. Percebe-se, pelo que já foi dito, que não se trata de um desejo qualquer, mas daquele afeito ao universo feminino e que ressoa nos trechos já destacados e em muitos outros.

Nas palavras de Eliana Calligaris (2006, p. 60), o "desejo de produzir desejo" é considerado como fundamental da constituição do sujeito feminino. Ao diferenciar a configuração edípica de meninos e meninas, expõe a importância do olhar do pai dirigido à filha para que esta se sinta amada. Para a autora, a fantasia de prostituição, o expor-se ao olhar alheio a fim de capturar o desejo de outrem, é um dos caminhos possíveis, senão o privilegiado, para, na vida adulta, a mulher vivenciar sua feminilidade.

Prostituição, do latim, segundo Bloch e Wartburg citados por Calligaris, significa "expor livremente: pro - na frente, statuere - colocar. Expor abertamente, colocar na frente". Para a psicanalista (2006, p. 60):

A mulher trabalha psiquicamente para fazer existir um corpo protegido, um corpo que não se exponha, que se mantenha a salvo do desejo paterno e no abrigo do amor. Por outro lado, fantasias que acenam para um gozo feminino levam-na a querer se expor e se entregar.

Esta breve reflexão faz pensar na condição de Leandra e seu enfrentamento tanto em relação a si mesma, mas, sobretudo, na sua forma de se apresentar diante do sogro. 
Sua condição na propriedade do Buriti Bom, por um lado, garante o "corpo protegido", como um troféu - ela também uma propriedade familiar - à espera do marido legítimo. No entanto, a frase destacada acima merece ser aqui repetida, por seu caráter lapidar: "Cada uma precisa de se sentir desejada... (B, 157, grifo meu)"

A fala de Lalinha vem de um diálogo entre ela e Maria da Glória. Interpelada pela cunhada sobre a naturalidade do seu "desejo de produzir desejo", de que "um homem de repente me abraçasse" ou de que "fazendo de conta que não noto, havia de gostar que um homem olhasse muito muito para minhas pernas...", Lalinha sintetiza e legitima aquilo que é próprio do feminino, na visão de Calligaris. Chama a atenção o endereço difuso do desejo de Maria da Glória, que "um homem" viesse a desejá-la, supondo que, da parte de Lalinha, o desejo fosse exclusivo em relação a Irvino.

A importância do desejo, assim como das vicissitudes da vida amorosa, das possibilidades de encontro e desencontro são alvo de várias conversas entre as personagens Maria da Glória e Lalinha. Para esta, a importância do "ser desejada" só vai crescendo, à medida que cresce, também, seu desejo por Maria da Glória. Questionando Lalinha se não seria a incompatibilidade sexual o motivo do casamento desfeito, esta aguça a percepção de si mesma, reconhecendo toda uma gama de desejos a compor seu desejo maior:

Pediu que a outra lhe acendesse um cigarro, precisava de um gole de tempo, súbito precisava: o insólito prazer - as imagens que lhe tinham acudido, completas -; e em parte mentir-se, porque $o s$ desejos, que violentamente se atribuía como antigos, somente àquela hora pela primeira vez lhe enriqueciam a mente [...]

- "Então, o que você queria, Lala, era o rei? Queria ser uma rainha?" [...]

- "O Rei, talvez, meu bem... Mas não para ser uma rainha..." Rainha? Como retrucar-lhe que queria talvez o contrário? O contrário de rainha? Às vezes, somente uma coisinha desejada... o pensamento atravessou-a! Calava-se. Calava-se muito. "Uma coisinha-desejada..." De novo a lene molice, o invasor prazer. (B, 200)

Desejo e prazer, juntos, de forma não usual, estranha (insólita), invadindo a consciência, como que burlando as barreiras do recalque, confrontando Lalinha com o que é estranho a ela própria, mas, aqui, dando a oportunidade de que ela se aproprie, de 
forma autônoma, daquilo que a constitui. Os "poros" que ela mesma estranhara em si mesma mostram-se abertos, quiçá por sua imersão na natureza amplamente erotizada deste ponto do sertão "retirado de rota", propício à manifestação de um modus vivendi "insólito" para esta personagem.

Ser rainha, como num conto de fadas, numa "lenda" (gênero dito propício ao feitio do Buriti Bom) não lhe interessa tanto quanto ser uma "coisinha desejada", destituída de realeza, comum, reles, talvez, por isso, estranha à grandeza do poder que emana do lugar. A “coisinha-desejada”, com hífen, liga de forma ainda mais definitiva o desejo ao Ser enquanto coisa, sendo, aqui, indissociáveis.

Quanto à fantasia de prostituição, o mostrar-se, oferecer-se aos olhos e ao deleite de Liodoro, é algo evidente por si mesmo ao longo das cenas que descrevem os serões no Buriti Bom. Apenas para que não se perca de vista a importância deste fenômeno, destacam-se aqui dois pequenos trechos:

Sua beleza era pasto. E o apetite dele, a reto, no nunca monótono, parecia mais grosso, sucoso, consistente. Lala se ensinava, no íntimo: que estava se prostituindo àqueles olhos; ora se orgulhava: e contudo ele a olhava como a uma divindade. (B, 220, grifos meus)

Ferisse-a, batesse-lhe, gritasse-lhe infames acusações - mas violador, macho, brutesco. Como poderia chamar-lhe? "Prostituta!"? E ela, desabrida - "Sim, sou uma, sim! Pois então?! Você me quer, me agarre, me use!..." - ela responderia, bradaria, de pé, vibradamente desvestida, e bela... Um homem!... (B, 232)

A tese defendida aqui da contraposição do poder do totem da fecundidade que rege o erotismo de Liodoro e o desejo, norteador da ação de Lalinha, encontra mais um ponto de apoio.

Note-se no trecho acima o termo "apetite", sendo a beleza "pasto" para o "touro" Liodoro, assim como a observação de Gualberto que fala do proceder do patriarca "por natureza" (B, 95), ou no pensamento de Lalinha sobre a índole do sogro: "o que ela pensava: iô Liodoro, só ele violando, por força e por dever, todas as mocinhas do arredor, iô Liodoro, fecundador majestoso." (B, 218, grifos meus). 
Em sua forma de agir, até porque o foco narrativo não dá espaço para isso, a atividade erótica de Liodoro é sempre descrita em termos "retilíneos", que não abrem espaço a dúvidas ou hesitações, quase como um automatismo: "apetite", "força", "dever", sendo ele um "fecundador majestoso", como num processo de polinização das "fêmeas", feito o vento ou uma abelha, ou como mais um trabalho da vida no campo, como a colheita ou a lida com o gado: "Iô Liodoro, infatigável no viver, voltando do amor de cada dia, como de um trabalho rude e bom." (B, 164/165) Vivendo numa espécie de ato contínuo, Liodoro é como o monjolo a bater o arroz na propriedade, tem seu ritmo determinado pela água que nele cai, de acordo com a quantidade maior ou menor de chuva, trabalha e exerce o "amor de cada dia" como quem reza um Pai-nosso de forma automática (“o pão nosso de cada dia, nos dai hoje”). Manifesta, assim, da maneira mais pura, o que aqui se defende como a concretização deste erotismo que emana da natureza, parte de um ciclo de fecundidade infinito, como as estações do ano, alternância entre estações de chuva e seca.

Para Lalinha, desenha-se um processo, um percurso, que desemboca na troca encenada no "brinquedo", no "jogo", lúdica encenação da descoberta feliz do desejo do outro a descobrir as fontes do seu corpo. Liodoro, como que saindo de seu automatismo, "a olhava como a uma divindade". Tal feito ressoa, por exemplo, com a observação de Miguel, ao ter seu desejo também despertado ao chegar no Buriti Bom e avistar Maria da Glória e seu brilho solar: "as deusas ferem" (B, 128).

Lalinha oferece-se como uma deusa, ou melhor, uma oferenda no altar da Beleza, fazendo-o, não sem sofreguidão, mas com nítido prazer. Tira, por instantes, Liodoro da "rudeza" de sua vida, oferecendo-lhe outra perspectiva, outro patamar no viver. Recebe em troca aquilo que procurara, vendo realizado seu "desejo de produzir desejo": uma coisinha-desejada. 
Capítulo 4 - O corpo da noite: da natureza erotizada ao corpo erógeno. 


\section{CAPÍTULO 4}

\section{O corpo da noite: da natureza erotizada ao corpo erógeno}

\section{Introdução}

O crítico Benedito Nunes (1969, p. 146) chama a atenção para o tratamento singular do amor na obra de Guimarães Rosa. Para o autor paraense, em que pese a reconhecida influência do pensamento de Platão sobre a escrita rosiana, sobretudo do diálogo $O$ banquete em se tratando do amor, esta influência se dá de forma "heterodoxa." 32

Em seu ensaio "O amor na obra de Guimarães Rosa”, embora não mencione "Buriti", Benedito Nunes faz considerações pertinentes para pensar o tratamento deste tema na novela em questão. Ele escreve (1969, p. 147): “o amor carnal conserva-se no espiritual”. Ao tratar do caráter não pecaminoso das relações sexuais, Nunes (1969, p. 149) pontua: "o amor carnal [...] é a primeira etapa de uma trajetória ascensional expansiva, que integra o prazer físico ao dinamismo da alma e converte o desejo sexual, sem extingui-lo[...]'E, talvez aí, possa-se compreender um dos sentidos possíveis para este platonismo heterodoxo.

Ao expor as ideias relativas à ascese amorosa, partindo dos ensinamentos de Diotima a Sócrates, Platão (1983, p. 42/43.) escreve: “que pensamos então que aconteceria, disse ela, se a alguém ocorresse contemplar o próprio belo, nítido, puro, simples, e não repleto de carnes, humanas, de cores e outras muitas ninharias mortais, mas o próprio divino belo pudesse ele em sua forma única contemplar?" (grifo nosso)

A leitura de "Buriti" atesta a importância da contemplação dos "belos corpos" (expressão platônica), ou, mais especificamente - mas não exclusivamente - o belo corpo de Lalinha, e até sua intenção de promover o bem no Buriti Bom a partir da relação que se estabelece nos serões noturnos entre ela e Liodoro: "Mas, ele me obedece, hei de levá-lo apenas a atos bons, para a felicidade de todos..." (B, 220 grifos meus). E aqui, mais uma vez, a escrita de Rosa se afina com o pensamento de Platão, na medida em que se aproximam o Belo e o Bom, assim como o bem comum: "Se portanto o Amor é carente do que é belo, e o que é bom é belo, também do que é bom seria ele carente" (1983, p. 33); e, mais adiante, em Platão (Idem, p. 40), se lê: “a

\footnotetext{
${ }^{32}$ Sobre a relação entre a escrita rosiana e a doutrina platônica, vide a correspondência de Rosa com Edoardo Bizarri, ou mesmo ensaios críticos como A raiz da alma, de Heloísa Vilhena de Araújo.
} 
mais bela forma de pensamento é a que trata da organização dos negócios da cidade e da família, e cujo nome é prudência e justiça [...]"

Mas, a hipótese defendida no presente estudo é que a diferença - ou a heterodoxia, no dizer de Nunes - se produz na medida em que Rosa insiste nas "ninharias mortais", da beleza em seu estado e condição humanos, residindo esta - a beleza - no corpo, fonte de dor e prazer, buscando não apenas a ascese em direção ao mundo das ideias e das formas puras, mas expressando a necessidade de um entendimento entre corpo e espírito.

A síntese deste pensamento pode ser lido na seguinte passagem de "Buriti": " $O$ amor exigia mulheres e homens ávidos tãomente da essência do presente, donos de uma perfeição espessa, o espírito que compreendesse o corpo.” (B, 192, grifo meu). Tratase de uma reflexão de Lalinha ao deparar com a necessidade de Glorinha de "falar de amor". Tendo a alma tomada pela presença de Miguel, de forma tão avassaladora como uma força da natureza, outro caminho se faz necessário: do falar, dar forma ao pensamento, fazê-lo encarnar: "Tomara de alma a presença daquele moço - contra ela sobrevinha assim como as chuvas da estação ou o florir de maio, milmente. Só pensava nele." (B, 191, grifos meus)

Lalinha ainda faz a ressalva de que se trate, talvez, de uma "sua preferência", dada certa semelhança de feição entre Miguel e Irvino. Portanto, ainda que enviesada pela perspectiva da personagem, a citação posta no começo do parágrafo anterior assinala a condição, não só de Lalinha, mas destas personagens - como Maria da Glória e Miguel - que estão no movimento de busca, entendimento, realização na esfera amorosa.

Um aspecto singular de "Buriti" é justamente a composição de um enredo no qual se observa, por parte de algumas personagens, esta busca por compreensão do corpo pelo espírito como uma das exigências do amor. Não se trata de considerar o amor carnal como uma fase a ser vivida e superada pelo movimento ascensional, mas um fenômeno que preza o pleno engajamento dos sujeitos, supondo do espírito este caminho em direção ao corpo na busca de uma possível "perfeição espessa."

Tal perfeição, diga-se, quiçá utópica em se tratando do ser humano, faz ressoar a harmonia da natureza e seus múltiplos elementos já estudados aqui. Como se viu, Rosa em sua literatura recobre o cerrado mineiro, desde os mínimos espaços até os marcos mais evidentes (Buriti Grande) de uma "espessa" eroticidade. No corpo a corpo das 
personagens com a terra, com o "corpo da noite", a utopia da perfeição espessa se refaz em forma de lenda, na concretude mesma do desenvolvimento narrativo, conforme a sentença do narrador acerca da essência do Buriti Bom: "ali nada podia acontecer, a não ser a lenda".

As referências ao corpo, ao todo e às suas partes, abundantes na novela, podem ser entendidas como a busca deste entendimento/compreensão, principalmente quando mencionado nos diálogos entre Lalinha e Maria da Glória, nos solilóquios da esposa de Irvino, ou quando o narrador capta os sutis movimentos dos serões entre Liodoro e a nora.

O homem que, ainda da derradeira vez, estudava em seu corpo, adivinhando, as nascentes do amor - como Deus a fizera - a beleza, a coisa. (B, 231)

Ele obedecia àquilo, a uma sombra inexistente - mais forte que a verdade de seu corpo - e seriam precisos anos, séculos para que aquilo se gastasse? (B, 233)

Tinha de ser bela, apenas. Sorrisse. Sorria, falava. Seu corpo se oferecia, desenhava-se mais capitoso a cada sutil movimento, a cada postura, dele voavam alegrias. (B, 233/234)

$\mathrm{E}$ - de repente, de repente, de repente - uma onda de viver, o viço reaberto de uma ideia. Lala sorriu, achou aquilo tão simples, tão belo... Seu corpo se enlanguesceu, respirou-se fundo, por ela. (B, 243)

Destaca-se aqui isto que é da linguagem comum, mas que, dado o uso literário, ganha força, a saber, os momentos em que o sujeito da frase não é o sujeito (personagem), mas seu corpo: "seu corpo se oferecia, desenhava-se"/ "seu corpo se enlanguesceu". Flagra-se a cisão corpo/espírito, de um lado, mas também a busca próxima, quase uma perseguição de um ao encalço do outro, como quando o "viço" termo usado comumente para falar da vegetação - de uma ideia súbita, semelhante a uma ideia que vencesse o recalque, invadisse a consciência e, daí, elanguescesse o corpo de Lalinha.

O corpo como "objeto de estudo" - vide citação da página 231 - tanto pode se dar no encontro de Liodoro e Lalinha como no desejo de Maria da Glória em entender o motivo do casamento desfeito entre seu irmão e a cunhada. Tal busca leva-a a inquirir Lalinha sobre as chances de sucesso entre sua possível união com Miguel. Isto porque Maria da Glória supõe que o motivo do divórcio poderia ser, enfim, o fato do casal não “combinar" em sua intimidade. Lalinha responde: 
"Certo, sobre cem, não tem, não, meu bem, infelizmente... Só depois, você compreende. Corpo com corpo..." - "É horrível, então! Mas, Lala, é horrível..." (B, 199 - grifo do autor)

Subentendidas estão as questões da perda da virgindade feminina e da possibilidade de prazer, que - de acordo com os ditames da sociedade patriarcal devem esperar o matrimônio para acontecer.

Esta passagem figura uma verdadeira encruzilhada para o leitor, merecendo maior atenção. Considerando a menção ao Jardim do Éden, estudada no primeiro capítulo, subentende-se, além do desfrute, a queda e a expulsão do casal mítico do paraíso edênico, mesmo que em "Buriti" os efeitos da queda ainda não se realizem de forma absoluta e inequívoca.

Marilena Chauí (1984, p. 86.), ao refletir sobre o pecado original e a queda em seu livro Repressão sexual, anota:

A queda, o distanciar-se para sempre de Deus, é o sentimento de um rebaixamento real e do qual a descoberta do sexo como vergonha e dor futura é o momento privilegiado. Com ele, os humanos descobrem o que é possuir corpo. Corporeidade significa carência (necessidade de outra coisa para sobreviver), desejo (necessidade de outrem para viver), limite (percepção de obstáculos) e mortalidade (pois nascer significa que não se é eterno, é ter começo e fim). O pecado original é originário porque descobre a essência dos humanos: somos seres finitos. A finitude é a queda. (grifos meus, com exceção do último)

Que não haja dúvida, portanto, da relação entre o contato do sujeito com esta parte de si mesmo que o constitui - o corpo - ou com esta soma de experiências corporais que sedimentarão a base do que se chamará mais tarde de "eu". A descoberta do sexo, da posse do corpo como quer Chaú́, traz a marca da finitude, do limite, do prazer possível (incerto) diante da morte certa. Da reflexão da filósofa para a realidade do texto e do embate das personagens femininas, não é difícil tirar algumas conclusões. Se as consequências da queda - evento mítico - se estendem sobre todo o gênero humano, por que as condições objetivas do prazer - mediado social e historicamente têm de ser diferentes, desiguais? A primeira resposta, quase automática, seria: justamente pelo fato desta possibilidade ser mediada social e historicamente, dependendo de condições que o passado mítico não pode garantir ou proporcionar.

Daí a indignação registrada na fala de Maria da Glória. Pode-se afirmar que neste breve diálogo entre Lalinha e Glória, em tom coloquial, revela-se a incerteza relativa à felicidade da donzela que aguarda o matrimônio. Este diálogo contribui para a 
desconstrução de certo mito afeito à questão amorosa, pois, pela troca de experiências íntimas, numa conversa reservada entre as moças, põe-se a nu alguns limites deste pressuposto patriarcal do casamento tradicional e o cuidado com a virgindade feminina. O trecho registra o momento em que se abrem os olhos de Maria da Glória para o limite de sua educação tradicional e o quanto isto limita sua possibilidade de escolha pessoal e, consequentemente, de felicidade futura.

Pensando com Roland Barthes (1980, p. 163): “Uma prestidigitação inverteu o real, esvaziou-o de história e encheu-o de natureza, retirou às coisas o seu sentido humano, de modo a fazê-las significar uma insignificância humana." O diálogo entre Lalinha e Glória, se não desfaz totalmente o caminho da naturalização da história exposta por Barthes, contribui para "encher" parcialmente de história o mito que estava "cheio" de natureza, relativizando seu poder e oferecendo outra perspectiva para o pensamento e as ações das personagens.

Guimarães Rosa cuida de articular ao longo desta novela diversos episódios de forma a mostrar perspectivas as mais distintas no tocante à questão erótica, entrelaçando e problematizando as matérias advindas do fundo mítico e do processo histórico, de forma a instigar o leitor a tirar as próprias conclusões relativas ao redemoinho amoroso configurado nesta narrativa. De forma sutil, o escritor mineiro oferece elementos para "desinverter" a prestidigitação identificada pelo pensador francês, revelando certos limites afeitos à mítica condição do Buriti Bom e sua ética peculiar.

Para a filha de Liodoro, cercada de exemplos estúrdios, como o relato de DoNhã, além das mulheres que são o (des)caminho do pai, vai parecendo absurda a restrição à qual teria de se submeter. A experiência vivida por Lalinha, matéria do diálogo em apreço, atesta que, para além de qualquer mítica promessa de felicidade no "antes", existe algo que só se descobre no "corpo com corpo", depois que os amantes se encontram no "agora", ou, como quer Lalinha, na "essência do presente".

Tal aprendizado, evidentemente, pode levar a caminhos inusitados, dependendo da trajetória de cada personagem. Enquanto Maria da Glória dá vazão ao seu imaginário erótico, Lalinha, diante da fantasia expressa pela cunhada, precisa afastar do pensamento o que esta fantasia evoca para ela.

- Lala, eu gostava de poder aparecer nua, nua, para que todo o mundo me espiasse... Mas, ninguém pudesse ficar sabendo quem eu era... Eu punha máscara... $(B, 205)$ 
Ela conhecia a nudez de Glorinha. Ela não queria pensar agora na nudez de Glorinha, tantas vezes entrevista, quando juntas se banhavam. (B, 205)

Esta passagem exemplifica a relação da matéria histórica e a abertura que se desenha para a questão erótica. A fantasia em questão se expressa após a menção ao "Carnaval" (com maiúscula). A historiadora Mary del Priore (2011, p. 149/150) menciona tais festas, focando a sociedade brasileira na década de 1950, ocasião na qual os ditames repressivos - sobretudo os relativos à figura feminina - eram postos de lado. Na síntese desta autora:

O carnaval era visto como uma festa perigosa, depravada, na qual "as ligações mais secretas transparecem, em que a virgindade é dúbia e inútil, a honra, uma caceteação, o bom senso uma fadiga". O desejo, sobretudo o feminino, engessado pelos bons costumes durante o ano, explodia nas fantasias e comportamentos espontâneos. Era "sem-vergonhismo" puro, no entender de alguns. Caminhada para a liberdade, no de outros. (grifo meu)

Além da vivência urbana de Lalinha, deve-se lembrar os afluxos de outros ares que chegam ao longínquo sertão por meio de revistas e romances, como anota, en passant, o narrador: "Ali tudo o que era escrito se guardava indefinidamente, havia pilhas de revistas muito passadas, e romances, alguns do tempo em que Irvino e Ísio, e as irmãs, ainda eram adolescentes.” (B, 173) Vale lembrar que as revistas, como por exemplo O cruzeiro, traziam, entre outras matérias, relatos e fotos dos carnavais passados na capital do país. Anote-se, portanto, pensando nos exemplos trazidos por del Priore em seu volume Histórias íntimas, sexualidade e erotismo na história do Brasil, que a fantasia de Maria de Glória é bem mais ousada que aquelas trazidas nestas revistas.

Não se trata, evidentemente, de um baile de carnaval, mas de um diálogo, conversa íntima durante a qual se menciona o carnaval, que serve como disparador ao livre curso da fantasia de Maria da Glória. A libertinagem típica do festejo e o convite à perda dos limites jogam mais uma vez tanto com o caráter expansivo da jovem sertaneja quanto com a autocensura de Lalinha, na medida em que evoca a nudez da cunhada, já "tantas vezes entrevista".

Nas páginas de "Buriti", como se vê, há ocasião para falar do desejo que nasce da contemplação dos "belos corpos" e que, nem sempre, se dirige ao sexo oposto. Podese afirmar até que o estudo de Liodoro em relação a Lalinha é algo que se dá, mediante circunstâncias específicas, análogo à intensa convivência e intimidade registradas na 
novela entre Lalinha e Maria da Glória, no "corpo com corpo", durante a qual registrase o nascimento da atração da jovem citadina pela cunhada sertaneja. Por isso, da mesma forma que Liodoro tem de obedecer à "sombra inexistente" - bela metáfora para falar das proibições estruturantes da cultura, como o tabu do incesto - que impede a consumação de seu desejo em relação a Lalinha, contrariando a "verdade de seu corpo", o mesmo se dá no caso de Lalinha em relação a Maria da Glória.

Ele obedecia àquilo, a uma sombra inexistente - mais forte que a verdade de seu corpo - e seriam anos, séculos, para que aquilo se gastasse? (B, 233)

A verdade do corpo, erógeno, pulsante - seja o da noite ou a das personagens em pé de igualdade com a verdade do mundo das ideias, contribui para a caracterização de "Buriti" como obra singular - retirada de rota - dentre os escritos rosianos. Essa ênfase no corpo pulsional, recebendo a mesma importância que o espírito, demandaria uma investigação ampla nos outros escritos do Rosa, o que certamente extrapola os limites deste estudo. Pode-se considerar, por exemplo, que "Dão-Lalalão", estudado no mestrado $^{33}$, é uma novela na qual se pode encontrar feito semelhante. O que chama a atenção em "Buriti” é justamente a ênfase do autor para salientar a importância do corpo e espírito sem que um desmereça ou se sobreponha ao outro.

\section{1 -Monjolo, marcador do desejo.}

"O barulhinho do monjolo cumpre um prazo regulado. Ele tem surdina e rotina."

$\mathrm{Na}$ imensidão da noite do sertão, distingue-se, mais uma vez, o som a orientar os habitantes do Buriti Bom. O prazo regulado cumprido pelo barulho do monjolo decorre, obviamente, de seu funcionamento, sendo impossível dissociar um de outro.

O monjolo é humano, reproduz a vontade de quem o fez e de quem o botou para trabalhar as arrobas de arroz. (B. 90/91)

O ranger do monjolo é como o de uma rede. O rego está com pouca água, daí a lentidão com que ele vai socando. (B. 85)

De artefato comum da vida sertaneja a figura importante na narrativa, o monjolo simboliza, de acordo com a leitura aqui proposta, a constância do impulso erótico ao mesmo tempo em que, por sua constituição, estabelece um elo entre o desejo humano e a natureza.

\footnotetext{
${ }^{33}$ Embora com enfoque relativamente distinto, algumas ideias expostas na presente tese já se encontravam, em estágio embrionário, na dissertação de mestrado: ROCHA, E. S. Prazer de sombra: uma leitura de "Dão-Lalalão", de João Guimarães Rosa. Dissertação de mestrado apresentada no Departamento de Letras Clássicas e Vernáculas da USP, sob orientação da Profa. Dra. Yudith Rosenbaum, 2009.
} 
Peça de madeira escavada que depende do fluxo de um curso d'água pra funcionar, não há dúvida de que ele "é humano". Escolher onde será construído, para que reproduza a vontade "de quem o fez", pressupõe, no entanto, um conhecimento prévio deste rio, "rego", o volume e o fluxo de água, o regime das chuvas etc. Evidencia-se sua condição de intermediário entre a vontade humana, perpassada pela rede da cultura, portanto, e a força da natureza. Seria uma imagem limiar ou de passagem entre uma e outra.

Pensado em termos analógicos, o ranger e a batida do monjolo, sua condição de peça manufaturada a depender da natureza para funcionar, remete ao conceito freudiano de pulsão. Ao refletir sobre a origem deste fenômeno, Freud (1915/2011, p. 57) afirma se tratar de um "conceito-limite entre o somático e o psíquico, como o representante psíquico dos estímulos oriundos do interior do corpo e que atingem a alma, como uma medida do trabalho imposto à psique por sua ligação com o corpo".

A imagem do monjolo a funcionar, seu sobe e desce constante, ritmados pelo fluir da água do rio, em constante pulsação, só reforçam a analogia acima sugerida, além de sugerir a imagem própria ao funcionamento do órgão sexual masculino. Quando Freud (1915/2011, p. 51) escreve sobre a "essência" da pulsão e suas características, afirma que sua origem se dá em "fontes de estímulo no interior do organismo, o aparecimento como força constante; e [...] sua irredutibilidade por meio de ações de fuga".

As "fontes" de onde jorram os estímulos constantes, no interior (no sertão) do organismo fazem funcionar este monjolo, figuração da pulsão erótica em "Buriti”. O "trabalho" - quiçá o "trabalho rude e bom" de iô Liodoro - "imposto à psique por sua ligação com o corpo" produz, nos habitantes do Buriti Bom, os diversos frutos colhidos ao longo da narrativa: além da vida erótica de Liodoro, o casamento "em anjos" de Ísio com Iá-Dijina (ex-prostituta), o casamento desfeito de Irvino que vai atrás da "outra" até o arvoramento expansivo de Maria da Glória e a busca de Lalinha pelo entendimento do “espírito" em relação à demanda do corpo.

A pulsão se apresenta como "força constante", assim como o fluir do curso d'água que nasce da terra, em relação ao qual não há como fugir. Joel Birman (2007, p. 60), sistematizando a conceituação freudiana, lembra que "a fonte da pulsão pode ser biológica, mas a pulsão enquanto tal não o é absolutamente." Insiste este autor no fato de que, para além da noção de organismo, mais afeita ao registro estritamente biológico, 
o que funda a noção de corpo para a psicanálise é justamente a "encruzilhada" (termo usado por Birman) entre os destinos pulsionais, incluindo aí, além das pulsões propriamente ditas, a ação do Outro.

Na esteira deste pensamento, Luiz Alfredo Garcia-Roza (2004, p. 255) salienta que "enquanto conceito fronteiriço, a pulsão articula o somático e o psíquico." Este trabalho de articulação implica basicamente na captura do disperso pulsional pelo aparato psíquico. Prossegue Garcia-Roza (2004, p. 251): "se de um lado temos pulsões anárquicas, de outro lado temos o aparato como o lugar da ordem, capturando e transformando as pulsões segundo uma ordem que é a da linguagem.” Em se tratando disto que é capturado e ganha representação na ordem psíquica, estamos falando de pulsão erótica e não pulsão de morte.

A "surdina" e a "rotina" (vide epígrafe desta seção), por sua vez, remetem ao funcionamento mesmo do monjolo. Tudo aquilo que em surdina se processa, debaixo da rotina manifesta da vida roceira, aguarda apenas o momento de vir à tona, tal qual a alternância entre dia e noite. Não se vê a pulsão trabalhando em sua origem, sendo esta processada em surdina. É possível, porém, ver sua irrupção na rotina, sua manifestação no plano das relações.

Após o primeiro encontro casual entre Lalinha e Liodoro, anota o narrador: "Encaravam-se, sem cismas, era como se entre eles somente então estivesse nascendo uma amizade. Podia ser. Quanto tempo durou? Combatendo o silêncio, o monjolo, o monotóm do monjolo; e os galos cantaram" (B, 212) A pulsão erótica, virtualmente infinita e capaz de tirar os futuros amantes do fluxo prosaico do tempo cronológico, desfaz a referência estrita do curso do tempo. De constante, apenas seu latejar, o "monotóm do monjolo" que, tirando-os do comum, os conduz, sem que percebam, até as barras do dia.

No mesmo trecho acima, note-se para a sutil encruzilhada disto que tira Liodoro e Lalinha do comum. Além da fascinação mútua, aqui prenunciada pelos olhares ainda pasmos e pelo silêncio, marca presença, como contraponto, o "mo/no/tóm// do/ mon/jo/lo", selando mais uma vez a importância do aspecto auditivo na fatura literária de "Buriti". Vide a vogal "o" sete vezes repetida, as consoantes nasais $\mathrm{m} / \mathrm{n}$ alternandose e o acento nas sílabas com "t” e “j”, com uma acentuação rítmica regular (pulsante) na terceira e na sexta sílabas (mo/no/tóm/do/mon/jó/lo). 
A música do sertão, ou a "submúsica" como quer o narrador, chega a cada um dos habitantes do Buriti Bom conforme sua capacidade de interpretar sua polifonia, ou de simplesmente se deixar levar por ela, como no caso de Lalinha e Liodoro embalados pelo latejar da atração mútua que os envolve como um mantra infinitamente repetido.

Se o conceito de pulsão é em si expressão de uma condição limítrofe, entre o somático e o psíquico, assim como o monjolo, limite do humano com a natureza, chegase neste ponto a uma reflexão toda ela entre os limites e os intercâmbios simbólicos inerentes à corporeidade em "Buriti". Sendo o "corpo da noite" expressão da erotização da natureza, é inevitável falar do contato desta natureza com o corpo das personagens igualmente noturno e erótico - e assim compreender o fluxo contínuo de um para o outro.

\section{2 - Os limiares do corpo}

Além da evidente importância do elemento sonoro, parcialmente trabalhada no capítulo 2, vale evocar aqui uma cena de "Buriti" que simula o banquete totêmico mencionado no capítulo 3. A cena em questão é regada a "vinho", mas não um qualquer, e sim um "vinho doce, espesso, no cálice, o licor-de-buriti, que fala os segredos dos Gerais, a rolar altos ventos, secos ares, a vereda viva.” (B, 225, grifo meu)

Nhô Gualberto é excepcionalmente admitido para jantar e dormir na Casa do Buriti Bom. A presença do elemento estranho perturba a rotina dos rituais noturnos entre Lalinha e Liodoro. No jantar, a presença da Maria Behú - "por fortuna” - à mesa, “diminuía nele (Gualberto) o poder de falar prolongado." (B, 223) Mal Behú se retira, e a cena parece caminhar para um festim que, gradualmente, trará a presença do que Lalinha identifica como o "mal"/a "maldade", mencionada em diversas formas ao longo do trecho.

$\mathrm{Na}$ realidade, esgarçam-se os limites que mantêm os acontecimentos e as personagens em suas condições socialmente aceitas, havendo ocasião para que o proibido se manifeste. Desestabiliza-se, sem que as personagens aparentemente se deem conta, o "malpreso" equilíbrio do Buriti Bom, dando, todos, sua parcela de contribuição para isso. 
Contrariando o hábito, Lalinha, durante o jogo da bisca $^{34}$, pergunta a Liodoro: “Acha bonitos os meus seios, vestida assim?" (B, 224), pergunta reiterada mais adiante. Glória, "burlona”, por sua vez "joga” com o Gualberto, não sem satisfação: "ela se delambia". O compadre, "salaz" (o mesmo que "libertino"), "escancarava a boca e se coçava nas pernas" (grifos meus).

Liodoro, no entanto, que, como Behú, "confiavam em todos à sua volta, não viam o mal em redor, não o presumiam" (B, 223), entusiasma-se e pede o restilo para brindar com Gualberto. O contentamento do patriarca se alarga: "quis mais, fez o que nunca acontecia, no comum - mandou que Glorinha trouxesse também o vinho." (B, 224/225, grifos meus)

Note-se que o banquete totêmico, a comunhão entre os partícipes se dá, ritualisticamente, com a entrada do vinho pelas mãos da filha de Liodoro. Luiz Roncari (2013, p. 176.) aponta a semelhança desta noite a uma "festa báquica".

Considerando a passagem anterior de "Buriti" na qual a carne e o "róseo sangue doce" (B, 126, grifo meu) do Buriti Grande aproximam a grande palmeira à eucaristia cristã, é o caso de assinalar aqui uma eucaristia às avessas, negativa, uma vez que através desse "vinho doce [...], no cálice, licor-de-buriti, que fala os segredos dos Gerais" (B, 225, grifos meus), o pecado, a maldade entram pelos meandros da cena e povoam a noite do Buriti Bom. ${ }^{35}$ Tudo isso, frise-se, se passa num dia santo: "e era um domingo." (B, 223)

Octavio Paz (1990, p. 108.) chama a atenção da importância do vinho e seus derivados, de forma contundente: "El vino ocupó siempre un lugar central em los ritos, fiestas y ceremonias de la antigüedad pagana y del Occidente cristiano. [...] homólogo del agua, del semen y del fluido espiritual, es fertilidad [...] Además, es el transmisor de la simpatía: exalta, comunica, reúne." Partilhado pelos convivas num momento de

\footnotetext{
${ }^{34}$ Importante lembrar que um dos usos do termo "bisca", além do jogo aparentemente inocente de cartas entre genro e nora, guarda também a conotação, segundo o Houaiss, de "prostituta". (HOUAISS, 2001, p.461)

${ }^{35}$ Cabe lembrar o sentido do sangue de Cristo, "derramado em favor de muitos, para remissão de pecados", de acordo com o Evangelho de Mateus, 26:28. Quanto ao "cálice”, mencionado na cena de "Buriti”, e o sentido de redenção e união, ver o versículo 27 do mesmo capítulo de Mateus: “A seguir tomou um cálice e, tendo dado graças, o deu aos discípulos, dizendo: Bebei dele todos" ou o Evangelho de Lucas, capítulo 22, versículo 20: “[...] depois de cear, tomou o cálice, dizendo: este é o cálice da nova aliança no meu sangue derramado em favor de vós”.
} 
celebração, não resta dúvida entre a relação deste símbolo - o vinho - com a conotação da cena aqui analisada, sendo possível usar - por coincidência? - os termos do escritor mexicano para descrever sua ação sobre as personagens: ele comunica um segredo, exalta os ânimos já despertos reunindo-os em torno de uma noite excepcional. Trata-se de uma pequena cerimônia particular que terá maiores consequências no decorrer da trama, aqui já próxima de seu desfecho.

A doçura do vinho embala a embriaguez, de forma que todos bebem, homens e mulheres, alegremente, em celebração da vida: "era a vida", "Não era a vida?", "a matéria ávida, a vida”. (B, 225) Ao final da cena Glorinha procura Lalinha e conta, aos prantos, que Gualberto a sujara e ambas, "tontas”, se beijam e se agarram “...Seus corpos, tão belas, e roçarem a borra de coisas, depois se estreitarem, trementes, uma na outra refugiadas..." $(\mathrm{B}, 226)$

Note-se, em todo caso, a fusão disto que chega e sai via oral, "os segredos dos Gerais", algo que se diz de modo sussurrado e furtivo, fundidos à doçura do vinho. Este murmúrio, de doçura sugestiva como um segredo ancestral, só se dá no contato entre a bebida ritual e o corpo dos que participam da celebração. Esta encruzilhada dos sentidos é justamente a entrada que se quer aqui assinalar.

Trata-se de pontuar parte deste artifício rosiano, que propicia um ambiente pleno de uma eroticidade própria que, no "corpo a corpo" com as personagens, acaba por transmitir, de múltiplas formas, esta emanação secreta que contribui para a manifestação erótica das personagens.

Este "recado", como se vê, não vem "do morro", mas de muitos outros elementos da natureza que, em "Buriti", se tornam verdadeiros depositários do erotismo humano. Viu-se a função do Brejão, assim como da sugestiva mata virgem onde se "enrolava o corpo da noite", além da noite ruidosa e dos totens - mutum e buriti - como elementos indiscutivelmente eróticos, cada um à sua maneira. A porta de entrada desta mensagem se dá não apenas pela audição, portanto, mas pode ser aqui tomada, sorvida, pelo paladar.

Sem desconsiderar a importância do universo sonoro, do apelo à audição para se guiar no escuro da noite, é pertinente considerar este contato das personagens com a matéria viva do sertão, assinalando, a partir desta comunhão, a múltipla funcionalidade e significação desta porta de entrada e saída, inequívoca zona erógena. Antes mesmo de se chegar à palavra, peça fundamental no intercâmbio erótico entre Liodoro e Lalinha e 
que une o oral, na articulação vocal, com o auditivo, vale atentar para alguns momentos da narrativa que focam a sugestiva presença da boca e sua função gozosa.

\section{3 - Boca da noite}

"O que era próximo e um, era a treva falando nos campos" (B, 114)

Além da "fala da treva", dimensão vocal do "corpo da noite", que se dispersa pelos campos e atinge o pavilhão auditivo de Zequiel e os demais habitantes do Buriti Bom, há que se considerar esta resposta, do que se articula labialmente nas personagens, das mais primitivas às mais refinadas reações humanas.

A cena do festim analisada acima traz dois exemplos: Maria da Glória "se delambia" enquanto Gualberto "escancarava a boca e se coçava nas penas". Do fino “delamber”, que também traz a conotação de envaidecer-se com si própria ou regozijarse, ao grosseiro escancarar da boca, vale notar o assomo de referências à oralidade como índice de prazer, volúpia, desfrute, apetite, sinais da comunhão entre o dentro e o fora seja o corpo da noite/sertão ou o sertão (interior) do corpo das personagens.

As amantes de Liodoro, na perspectiva do guloso Gualberto, se destacam pela lascívia bucal: "A boca sempre molhada, vermelha" que dá "apetência de cobiça" (B, 120), de Dionéia ou a mulata Alcina, que "Até no ela comer comida ou doce o senhor toma impressão que ela está fazendo coisas" (B, 121). Pode-se dizer que Gualberto, chamado em certa passagem de "Gula Berto" por sua esposa, tende a se destacar dos demais personagens por sua acentuada oralidade, que quer tudo abocanhar: sejam as terras que não servem à sua gula capitalista pelo lucro - "Eu como aquilo!" refere-se ele ao Brejão-do-Umbigo - sejam as mulheres alheias, ou mesmo as "sobras de intimidade" que caem da mesa de seu compadre. Daí, para ele, como num espelho, ganhar destaque nas descrições destas mulheres a apetência da boca e do que se pode fazer com ela.

Mais evidentes e sugestivas são as passagens envolvendo Lalinha e Maria da Glória. Lalinha, que já no apelido informal traz a relevância das consoantes labiais, logo nas primeiras linhas da segunda parte, toda dedicada à perspectiva desta personagem, recebe da cunhada um beijo "com gula", "no rosto". Ao se sentir reassegurada de que Miguel gostara dela, a filha de Liodoro "[a]tirou-se a Lalinha, com seu jeito de abraçar - que avançava impensado e brusco, mas, no empolgar, se rendia, em maciez e delicadeza." (B, 145)

A reação de Lalinha diante da franca demonstração de afeto da cunhada caminha da imediata atração para o progressivo distanciamento, propiciando a reflexão sobre o ocorrido. 
[...] mas a outra olhava para sua ávida boca, como se esperasse tê-la remolhada de leite e recendendo a seio. - "Lala, Lala, eu gosto demais de você, demais..." Lalinha retribuía aquele afago, que, todo lhe sendo grato, despertava também um sentimento sério de si mesma. Avaliava-se mais velha, ajuizada. Nesses momentos era que podia deter uma noção hábil de sua experiência, ciência já atacada pela vida, pago um preço. Lalinha sempre se vigiava. (B, 145, grifos meus)

A referência à amamentação na sequência do beijo guloso da cunhada remete à mais primitiva experiência de satisfação do ser humano, marcada aqui pela avidez da boca de Maria da Glória e pela reiteração do afeto. A atração se dá, diga-se, num meio em que os sentidos e sensações se misturam: o contato dos corpos no abraço e o beijo evocam ainda a visão, o olfato e o paladar, fazendo mesmo lembrar a situação de mãe e filha envolvidas no aleitamento.

Neste contexto, Lalinha vê mais do que há na cena, dando espaço para a fantasia, expressão do desejo e, neste sentido, a escolha dos tempos verbais é decisiva - com o subjuntivo destoando dos demais, no pretérito do indicativo - associada ao condicional "como se". Tudo isso, curiosamente, acende a necessidade de um relativo recuo, assinalado pelo conhecimento de si, de sua "experiência", que demanda de sua parte uma vigilância constante.

Cabe salientar a ligação da fantasia com a pulsão erótica, sumariamente apresentada acima. Para a psicanalista Susan Isaacs, desenvolvendo as ideias de Freud, a "expressão mental do instinto é a "fantasia" inconsciente. A fantasia é [...] o corolário mental, o representante psíquico do instinto. Não existe impulso, nem ímpeto ou reação instintivos, que não sejam experimentados como "fantasia" inconsciente." Mais adiante, esta mesma autora insiste: "todos os impulsos, todos os sentimentos, todos os modos de defesa, são experimentados em fantasias que lhes incutem vida mental e mostram a direção e propósito daqueles." 36

Sem pretender enveredar pela análise das motivações inconscientes de Lalinha, não deixa de ser instigante pensar a natureza deste tipo de imagem - a "ávida boca" da

\footnotetext{
${ }^{36}$ ISAACS, S. "A natureza e a função da fantasia” in KLEIN, M. 1978, p. 96/97, grifos da autora. Sem pretender entrar na discussão entre o uso do termo "pulsão" ou "instinto" ou ainda "impulso" para a tradução do Trieb alemão, usamos aqui, preferencialmente, o termo pulsão por distanciar-se do fenômeno conhecido por instinto, mais próximo do campo semântico relativo à vida animal. Diferentes autores e traduções, como o caso do texto de Isaacs, podem trazer instinto ou impulso no lugar de pulsão. Para uma discussão aprofundada sobre esta polêmica, remetemos à obra As palavras de Freud de Paulo Cesar Souza, 2010.
} 
cunhada remolhada de leite e "recendendo a seio" - que subitamente eclode no texto, via narrador, após Maria da Glória ter demonstrado seu afeto ante o gesto reassegurador da outra. Lalinha desejaria que todo este entusiasmo da jovem sertaneja fosse para ela, com a avidez de uma criança que mama e se entrega à mãe? Pergunta que, aqui, ficará sem resposta, mas que pode servir para entrada de futuras investigações.

De qualquer forma, esta primeira cena dá o tom do desenvolvimento da trama nesta segunda parte da novela. A intimidade entre Maria da Glória e Lalinha, da qual pouco se sabe na primeira parte, aqui é registrada com bastante insistência, seguida dos solilóquios de Leandra. Um constante movimento de aproximação - como o abraço e o beijo guloso - e distanciamento - no qual Lalinha vigia, perscruta a si mesma - pode ser encontrado aqui, em graus variados.

O enamoramento de Maria da Glória por Miguel é o disparador desta longa reflexão sobre o amor sob a perspectiva de Lalinha. Como num espelho, o "ameigamento melancólico" da jovem sertaneja suscita a recordação da chegada de Leandra ao Buriti Bom, passando pela rememoração de sua adolescência e juventude tendo como fio condutor a questão amorosa. Mas, sobretudo, o que se lê nesta parte da narrativa é uma busca em ritmo lento, compasso de longa espera, no qual há os longos momentos em que Lalinha e Maria da Glória nada fazem, abrem ocasião e caminho tempo e espaço - para pensar, fantasiar e experimentar as múltiplas faces de Eros, o que remete, necessariamente, ao corpo.

Sabe-se, com Freud (1923/2011, p. 32), que o “o Eu é sobretudo corporal”, e que “o Eu deriva, em última instância, das sensações corporais, principalmente daquelas oriundas da superfície do corpo. Pode ser visto, assim, como uma projeção mental da superfície do corpo, além de representar [...] as superfícies do aparelho psíquico.” Mais do que fazer referência às experiências corporais representadas no texto, trata-se de falar do lugar mesmo de onde nascem as experiências que possibilitam a constituição do Eu e, portanto, da fantasia.

Não é difícil constatar, na leitura deste trecho em que Lalinha e Maria da Glória parecem sideradas uma pela outra - ou de muitos outros trechos de "Buriti" - o próprio cerne da literatura erótica, por tudo o que vem sendo desenvolvido até aqui e que pode ser sintetizado na elaboração de Eliane Robert Moraes (2015, p. 20): "Não há erotismo sem fantasia, assim como não há literatura sem ficção. O princípio ativo da vida erótica coincide, portanto, com o da criação literária, uma vez que ambos se movem ao sabor 
dos desejos que jamais se esgotam em si mesmos e sempre ensejam um mais-além no horizonte".

Não há como falar em fantasia desencarnada. Quando vertida em verso ou prosa, esta é resultado de longo percurso, da pulsão à sua representação - a fantasia - até sua fixação em texto, resultado do labor literário. Assim, de forma análoga à constituição das zonas erógenas, fontes de excitação espalhadas pelo corpo que servirão de base para todas as fantasias possíveis, pode-se ler na ficção os signos que compõem a eroticidade do texto. Literatura, fenômeno corporal: nascida do corpo, ganha independência para, posteriormente, afetar outros corpos. O caminho é duplo: o erótico se ficcionaliza e a ficção ganha em erotismo.

No caso da referência ao aleitamento imediatamente após o beijo, como se disse, remete-se ao prazer oral, infantil, matéria amplamente estudada pela psicanálise. Além da passagem analisada até aqui, ressalte-se que Lalinha, esta que "fala" na segunda parte da narrativa, traz em seu nome o radical do verbo grego lalein, como já observou Adélia Bezerra de Meneses (2010, p. 127), que quer dizer "falar". Percebe-se facilmente a associação deste dado com a prática do serão com Liodoro, todo ele mediado pela palavra no circuito do olhar/nomear/ouvir/olhar. Este erotismo verbal é também, necessariamente, oral. Como já se disse, da reação mais espontânea à meticulosa articulação das palavras no diálogo erótico entre Lalinha e Liodoro, percebese um rico espectro de imagens sugestivas.

Do desejo em relação à cunhada com a boca recendendo a seio e leite outro momento de intensa mobilização da oralidade é registrado após um dos serões com Liodoro: "Sentia-se os lábios úmidos demasiado, molhados, como se tivesse beijado, como se tivesse sugado, e era uma seiva inconfessável. Depois, um deixo amargo, na boca. Assim adormecia." (B, 220)

Tão intenso é o envolvimento de Lalinha após o encontro que o adormecimento registrado ao fim do trecho remete à observação de Freud, ao falar da satisfação do bebê após ser amamentado que logo adormece, numa aproximação com o orgasmo. ${ }^{37}$ Embora o narrador insista na expressão "como se tivesse", marcando a distância entre a fantasia

\footnotetext{
37 "O chuchar, que já aparece no lactente e pode continuar até a maturidade ou persistir por toda a vida, consiste na repetição rítmica de um contato de sucção com a boca (os lábios), do qual está excluído qualquer propósito de nutrição. [...] O sugar com deleite alia-se a uma absorção completa da atenção e leva ao adormecimento, ou mesmo a uma reação motora numa espécie de orgasmo.” (FREUD, S. 1905/1996, p. 169).
} 
e o que de fato ocorrera, prevalece a força da fantasia que tem o poder de envolver a personagem até o ponto de levá-la ao momento de distensão característico, posterior ao encontro sexual. Saliente-se que ao anotar o "deixo amargo, na boca" o narrador não usa o "como se tivesse", apenas o advérbio de tempo "depois" como que a aproximar o efeito da fantasia sobre o real do corpo.

Enumere-se ainda os derivados que passam pelos lábios de Lalinha, numa breve enumeração: o "vinho doce", licor de buriti, o beijo (saliva), até a fantasiosa "seiva inconfessável" (sêmen?), de efeito incontestável. Mas, sem dúvida, o "brinquedo" inventado por Lalinha e Liodoro merece destaque por fazer, em toda sua complexidade, a palavra ganhar estatuto tátil, como se verá a seguir.

\section{4 - Encruzilhada dos sentidos.}

Vale analisar aqui um procedimento que talvez não seja restrito à fatura literária de Guimarães Rosa, mas de qualquer forma notável em "Buriti". Trata-se, sem dúvida, de um produto do fazer poético, que demonstra certa inconformidade do autor com a representação das sensações corpóreas, e busca romper e/ou fundir os diferentes campos perceptuais, expressando algo além do ordinário, como nos exemplos abaixo.

Ao comentar a situação do Chefe Zequiel, em fase de agudo sofrimento, o narrador anota: "E, agora, em piora, mudara: nem ia mais à roça, se esquivava das pessoas [...] Negava-se a relatar o descomposto das visões que seus ouvidos enxergavam." (B, 208, grifo meu)

Mais que uma sinestesia na fusão dos sentidos, o texto sugere uma transfiguração da própria matéria sonora em visual, o som se materializa, assim como a natureza se sexualiza (vide capítulo 1). Trata-se de ir além das expectativas, trazendo a riqueza de um campo a outro (no caso o visual ao auditivo), tornando ainda mais complexo o que já não era simples. Imagine-se - no sentido de tornar o som imagético e de fazer um esforço mesmo para vislumbrar conscientemente - todos os graves, agudos, modulações infinitas dos mínimos sons transmutados em categorias de luz, sombra, matizes também infinitos a compor um quadro visualmente "descomposto". Se Zequiel já era considerado fraco das ideias, não é de estranhar que esta transfiguração caracterize a piora de seu quadro.

Ao descrever o primeiro encontro entre Lalinha e Liodoro, o narrador anota que era "como se ambos representassem apenas no plano esvaecente dum sonho" (B, 215, grifo meu). Tão importante quanto pensar no conteúdo da cena que virá a seguir é 
atentar para a escolha desta moldura - da qual se falará à frente - sugerida em termos oníricos e marcada pelo condicional "como se". Tudo isto marca a excepcionalidade da sequência, retirando de rota mais uma vez o narrado.

Seus olhos intensos pousavam nela $(\mathrm{B}, 215)$

Ele falou. E era um modo apenas de acariciá-la com as palavras. Ela sorriu, sorriuzinho. (B, 215)

Devagar, a manso, falavam de tudo nela, os olhos e as palavras dele quentemente a percorriam. Parecia um brinquedo. (B, 216) Apenas, com medidas palavras, animava-o a insistir no falar, - ele devia tomar a diligência da conversa. $(B, 217)$

Podia oferecer-se mais: em palavras - as coxas, as ancas, o ventre esquivo. [...] - "Os seios, tão produzidos, tão firmes..." - era como se a voz dele a pegasse, viesse-lhe ao corpo. Mas, não, não poderia nela tocar, disso não havia perigo. A curta distância quase arfante - era adorável senti-lo. (B, 219, grifos meus em todas as citações)

O que se lê, retomando as considerações acima, são lances em que a voz e a palavra dita são dotadas de características táteis, transfiguração da matéria auditiva e simbólica em corpo que toca. Os ouvidos enxergam - Zequiel - assim como a voz e as palavras de Liodoro pegam, acariciam e percorrem o corpo de Lalinha. Os olhos "pousam" no galho da Leandra, flor personagem. Se pousa, toca, faz sentir seu peso, expressão do universo tátil.

Eduardo F. Coutinho (1973, p. 206/207) aponta para "a estranheza das construções" do autor mineiro, que, segundo o crítico, fere a percepção do leitor, levando-o a uma reflexão sobre o lido, de forma a enxergar além do usual. A transgressão do uso comum das palavras e expressões - marca registrada da escrita rosiana e, no fundo, de todo grande escritor - leva aqui o leitor a "explorar o inexplorado", jogando-o no centro deste território insólito no qual se desenrola o ritual noturno onde o corpo e a palavra se tornam, virtualmente, uma só e mesma coisa.

A excepcionalidade desta construção, fusão dos diferentes estatutos da matéria, remete ao mecanismo de condensação onírica descrito por Freud (1900/1996, p. 670.), na medida em que é possível aferir a proximidade do mecanismo capaz de criar "formações compostas", resultado da junção entre diferentes ideias a serem representadas no sonho. Aqui, características perceptuais distintas convivem na mesma expressão, criando algo inusitado, afeito ao discurso poético, mas facilmente encontrável num contexto onírico. 
A mesma categoria do sonho, como se disse, serve de moldura para a abertura dos encontros de Liodoro e Lalinha. O próprio Guimarães Rosa (1979, p. 157) associa a feitura de "Buriti" a um sonho "duas noites repetido" que ele tivera. Neste lugar "retirado de rota", cria-se uma ocasião, particular delimitação de tempo e espaço, para um acontecimento ainda mais excêntrico, como um parêntese dentro de outro.

Se o "como se" marca a distância entre o plano mais imediato da ação narrada e a fantasia, o "sonho" marca a proximidade desta mesma ação com o registro da realização do desejo. Nesse redemoinho, como nas citações acima, os termos grifados indicativos de uma condicionalidade - marcam a distância de "faz de conta",38 enquanto a performatização da cena em si aponta para a aproximação, realização deveras, sonho real.

Apenas, com medidas palavras, animava-o a insistir no falar Tudo excitava - inconcebível, arrebatador como se lido e escrito. (B, 217, grifo meu)

Podia oferecer-se mais: em palavras - as coxas, as ancas, o ventre esquivo. (B, 219, grifo meu)

As palavras, nascidas no interior do corpo, ganham especial atenção ao longo dos encontros, nos quais se exploram justamente todo seu potencial excitatório, como se o "lido" e o "escrito" 39 pudessem e estivessem sendo postos em prática. Para mostrar a Liodoro - força da natureza, libido sem freio - outra possibilidade de realização erótica, ao invés de repressão, Lalinha apresenta outro tipo de excitação, mais afeita ao plano simbólico, jogando com o duplo registro da palavra, naquilo que ela tem de material e imaterial. Daí, talvez, o entendimento desta construção rosiana, uma palavra que pudesse ter o mesmo efeito do encontro dos corpos, proporcionando o agenciamento tátil nos corpos dos personagens, acrescentando mais uma dimensão de sensibilidade além das já ativadas: visão, audição.

Intercalam-se no entrecho dos serões, portanto, o sonho tornado real mediante a linguagem ficcional, cujos exemplos são as expressões acima destacadas e o distanciamento que marca a diferença do clima "esvaecente" do sonho com a realidade socialmente compartilhada. E por mais que se queira indicar que o que prevalece é a

\footnotetext{
${ }^{38}$ O crítico Franklin de Oliveira $(1991,68)$ é taxativo ao afirmar que as "estórias" de Guimarães Rosa "são contos de fadas adultos."

${ }^{39}$ Ao associar o lido e o escrito ao inconcebível e arrebatador que tem a capacidade de excitar, pode-se cogitar aqui se Guimarães Rosa não estaria fazendo uma menção aos escritos que compõem o corpus da literatura erótica à qual o autor - leitor voraz - muito provavelmente teve acesso.
} 
realidade - pois, ao fim e ao cabo, ambos sabem distinguir quem são e onde estão, ficando o encontro amoroso para depois da notícia do nascimento do filho de Irvino e a "outra" - não se deve esquecer o efeito que o sonho tem sobre o corpo, seja a angústia seja a excitação sexual que o narrador igualmente anota.

A comunicação entre Lalinha e Liodoro vai além da mera encenação, graças à participação ativa do narrador. Ao mesmo tempo em que marca a proximidade, o contato, insiste em assegurar a distância. Elide a distância - sobretudo quando se lembra que se trata de um sonho onde tudo é possível - para pouco depois marcar a condicionalidade: “como se”, "parecia”, “um modo apenas”. Guimarães Rosa usa e abusa do poder da palavra, sua capacidade de evocação e sua ambiguidade, seu dizer não dizendo para depois desdizer e redizer.

E nunca falavam de outra coisa - que não da desejável formosura de Lala, de seus encantos (B, 220)

Palavra, veículo privilegiado da excitação e do encontro amoroso possível entre sogro e nora. Palavra que contorna e toca o corpo, palavra tornada corpo, corpo tornado palavra.

Este procedimento, semelhante a um redemoinho que põe tudo a rodar, fazendo circular os significantes e seus significados usuais, evoca o achado de Antonio Candido ao escrever sobre Grande sertão: veredas. Em seu clássico estudo "O homem dos avessos" o crítico, após apontar diversas ambiguidades que constituem o romance uma natureza real na aparência, mas carregada de simbolismo, o homem fruto do meio que se impõe sobre o meio, a busca do mal para fazer o bem, entre outros - conclui nos seguintes termos: "há em Grande sertão: veredas uma espécie de grande princípio geral de reversibilidade, dando-lhe um caráter fluido e uma misteriosa eficácia. [...] Estes diversos planos da ambiguidade compõem um deslizamento entre os polos, uma fusão de contrários, uma dialética extremamente viva”. (CANDIDO, 1971, p. 134/135.)

Para o romance de Rosa, permeado pela violência jagunça e pelo conflito entre o bem e o mal, encarnado na dúvida da existência do diabo e na consciência dividida de Riobaldo, a formulação de Antonio Candido é de uma precisão indiscutível. "Buriti" é uma novela, como se pode ler, dedicada principalmente ao amor e suas possibilidades de realização.

A princípio, pode-se dizer que existem mais diferenças que semelhanças. Destaque-se aqui, mesmo assim, a ideia da reversibilidade, que evoca o movimento de um significante que passa a se apresentar conotando sentidos diversos daqueles que 
usualmente carregava. É isso que torna possível a erotização da natureza, a audição se tornar visível, a palavra ganhar corpo, a alma compreender o corpo na busca da "perfeição espessa".

Para um escritor que acredita na identidade entre a linguagem e a vida, e que compara sua relação com a língua em termos de uma relação entre amantes (LORENZ,. p. 83, 1973), nada mais coerente do que compor um texto marcado por esta possibilidade de reversibilidade, da "modificação de realidades linguísticas" (Idem, p. 92) característica da poesia, ou da prosa poética que marca o estilo do autor.

\section{5 - Corpo com corpo}

De forma semelhante ao que acontece em Grande sertão: veredas, retomando o estudo de Antonio Candido citado acima, a constituição do espaço narrativo e seus habitantes são indispensáveis para o entendimento do enredo. Já se falou da relevância da natureza, que atua como um personagem, para a interpretação aqui empreendida. Fato relevante é marcar a importância do espaço privado, restrito, da Casa - grafada com maiúscula em mais de uma passagem de "Buriti". Pois é no interior de seu corpo solidamente constituído que há a ocasião para o pulsar dos encontros entre Liodoro e Lalinha.

"A Casa - vagarosa, protegida assim, Deus entrava pelas frinchas.” (B, 214), "[...] e o quotidiano das paredes do casarão, que negavam todo extraordinário." (B, 212), "A tanto que amava o Buriti Bom - Lalinha suave soube - a Casa, todos [...]" (B, 213). À sua maneira, Rosa parece tomar a expressão popular "as paredes têm ouvidos" para dizer que a Casa, ela também, participa da trama, no seu ritmo peculiar de existência, "vagarosa", relação particular com o tempo, que nega o extraordinário embora faça parte dele.

Em seu interior, no entanto, haverá ocasião para a subversão do uso cotidiano do corpo no espaço de convívio familiar. Os limites que circunscrevem o prosaísmo das relações das personagens, seus lugares socialmente estabelecidos parecem ser relativizados quando, a certa altura na narrativa, o "corpo da noite" toca e envolve a Casa.

Tudo se dá de forma gradual, inocente, quase arrastada, com a substituição de Nhô Gualberto por Lalinha no jogo de bisca. O jogo, reservado aos homens, passa a ser rotina nas tardes do Buriti Bom entre o patriarca e sua nora. Mas, muito antes, outro “jogo" já fora tentado, sem sucesso. 
Quando Liodoro vai à cidade buscar Lalinha, registra-se verdadeiro choque de realidades. Após convidar a nora a passar uma temporada no sertão, Liodoro vai pedir ao irmão de Lalinha autorização para a viagem. Indignada com esta forma de agir, partindo de um "desusado homem de outro tempo", ela busca, num "jogo febril” (B, 149) provocar o escândalo de Liodoro, como se pudesse por a prova sua real decisão de levá-la consigo. Veste roupa sensual, "que mais se abrisse, mais mostrasse", "sapatos de pelica vermelha", maquiagem pesada, "se exagerou." (B, 150) Embora Lalinha tudo faça para chamar a atenção, pondo-se à mostra, de forma semelhante - mas não idêntica - aos serões, o propósito aqui é chocar, captar nas expressões corporais do sogro algum sinal de relutância, dalguma dúvida quanto à força do seu intento. No entanto, nada acontece, prevalecendo a impávida sisudez de Liodoro, firme em seu propósito: não há nada mais importante, neste momento, que salvaguardar a honra de Lalinha e, consequentemente, o nome de sua família. Não há jogo possível.

É preciso que Lalinha entre "no jogo", começando por aceitar o convite de Liodoro, fazendo parte do cotidiano deste lugar "retirado de rota", "isolado e remoto uma grande casa, uma fortaleza, sumida no não-sei” (B, 150)

O jogo da bisca, atividade corriqueira e sem maior importância, ganha diferente conotação quando jogado por Lalinha. Liodoro é o primeiro a reconhecer, louvando o talento da nora com as cartas. Questão fundamental, logo anotada pelo narrador, é que esta nova disposição das personagens no espaço da Casa, Lalinha diante de Liodoro, entremeados do baralho, tem implicações também para a passagem do tempo: “Também ela se entregava ao gosto do jogo, tomava-o como uma robusta obrigação, um marco do tempo." (B, 190, grifo meu)

O que Lalinha talvez não esperasse é a expectativa nela depositada por Behú e Glorinha em relação à possibilidade destas partidas reterem Liodoro em casa, evitando que ele saísse à procura das amantes. Diante da decepção estampada nas feições das cunhadas e do enfado expresso pela própria Lalinha vem um momento decisivo para a posição crítica da jovem em face do ambiente que a acolhe, mas que, simultaneamente, a faz sentir-se aprisionada, como "cravada borboleta".

Por tudo isso, deveras, quando as noites sempre iguais do Buriti Bom se abrem aos encontros de Lalinha e Liodoro, como já se disse, o acontecimento tem conotação equivalente ao de um sonho. Nos encontros registrados pelo narrador, prevalece a atmosfera de sonho, "brinquedo", "culto terrível" (B, 216), algo que "parecia um 
milagre" (B, 220). O inocente jogo de bisca desdobra-se, debaixo do mesmo inocente teto da Casa, no jogo da bisca, prostituta, de acordo com a própria Lalinha: "Lala se ensinava, no íntimo: que estava se prostituindo àqueles olhos (B, 220), ou, mais adiante: “Como poderia chamar-lhe? "Prostituta!"? E ela, desabrida - "Sim, sou uma sim! Pois então?! Você me quer, me agarre, me use!” $(B, 232)$

Dessa forma, quando a carta de Irvino anuncia o nascimento do filho e o fim dos serões, o narrador registra a reação de Lalinha:

E entendia: um despertar - despertava? E a vida inteira parecia ser assim, apenas assim: um seguido despertar, de concêntricos sonhos - de um sonho, de dentro de outro sonho, de dentro de outro sonho... (B, 237)

E, de fato, os serões dependem de um acúmulo de sucessivas excepcionalidades, excentricidades, a começar pela definição do lugar, "retirado de rota", propício à "lenda", de natureza singularmente erotizada a circundar uma Casa igualmente viva. Somente sob tais condições é que acontece o "milagre". O sonho se esvai completamente, a eterna repetição dos serões perde o sentido, abre-se o caminho para o realizar que só pode se dar desperto no fluir do tempo.

Após longa estada na fazenda, misto de espera e busca, o despertar de Lalinha demarca o "paraíso perdido" ao mesmo tempo em que abre o caminho para a realização do que se sonhara, caminho para a "terra prometida". Ao se encontrar livre, enseja-se a possibilidade de sair do tempo cíclico que marca a vida no Buriti Bom e finalmente retomar o curso de sua vida, no fluir do tempo histórico. Decidida a partir, propõe a consumação, em ato, de tudo o que se vislumbrara e só se sustentava pela mediação da palavra. Neste ponto, Lalinha, centrada em si mesma, ciente de seus desejo, limites e possibilidades, demonstra não fazer mais parte do clã, ela mesma excêntrica:

[...] nem Glória a entendia. Tudo o que falava, leviana, prazerosa - tudo era para mostrar, a ele, que ela já era mesmo uma estranha, uma mulher, prestes a deixá-los, sem perigo de comprometê-los, de contagiar o Buriti Bom com seu ser. Nem o olhava. Sabia que o corpo de iô Liodoro estava vivo ali, ouvindo-a, vendo-a; isso bastava. (B, 243/244 - negrito do autor)

As palavras são, então, postas de lado. Sumariamente, Lalinha queixa-se da demora do amante e insiste para que encham "bem as horas..." (B, 244) Restando pouco tempo, o que vale é a forma como os seres se empenham em aproveitá-lo. Dando um passo adiante em relação à repetição ritual dos encontros noturnos, que cumpriram a função de elevar ao máximo a atração e o desejo de um pelo outro, ambos podem se 
deixar levar no curso do tempo histórico que, finalmente, parece atravessar o "belo poço parado" do Buriti Bom.

Movimento análogo se dá no caso de Maria da Glória. A narrativa de Do-Nhã e sua sui generis experiência amorosa aguça a curiosidade da jovem. Além disso, as palavras carregadas de significação erótica dos serões entre Lalinha e Liodoro já podiam ser encontradas, à sua maneira, nas conversas diárias registradas entre as cunhadas. Entre confissões, receios, expectativas, o imaginado ganha expressão, fantasia nascida do corpo fazendo circular sua forma e conteúdo nos diálogos das jovens espalhados pelo texto. Exemplo disso é a já mencionada fantasia de Glorinha em aparecer nua, de máscara posta diante de homens desconhecidos. O narrador anota, pouco depois deste trecho: "era preciso falar, imaginar mais coisas, para evitar que de repente pudesse atenuar-se em seu pensamento o colorido fluido, a substância de que aquele mundo se criava." (B, 206, grifos meus)

A proximidade destas personagens, unidas pela mesma demanda relativa a Eros, leva-as a caminhos semelhantes. Se Maria da Glória em dado momento censura as mulheres que fazem a "perdição" do pai, cujas saídas "avolumavam pecado", próximo ao fim da novela acaba adotando conduta parecida à do genitor, ratificando a herança dele recebida. Após sucessivas lufadas de acasos significativos - a carta de Irvino, a morte de Behú, além da primeira e decisiva visita de Miguel - a jovem sertaneja segue o modelo do pai: "Iô Liodoro - ela já sabia o motivo que o levava a sair a cavalo, à noitinha" (B, 158), "Ele saía, montava a cavalo, ia ver a mulher baiana." (B, 219) "Glorinha se fazia selvagem: em galopar, passava boa parte dos dias fora de casa" (B, 240, grifos meus).

Mas, ao contrário do cenário privilegiadamente privado para os encontros de Liodoro e Lalinha (afinal de contas o patriarca pode dispor do espaço da Casa, mormente quando todos dormem), Glória busca o Alto-Grande ${ }^{40}$, "lugar escondido, bonito" para seus encontros sexuais com Gualberto.

Maria da Glória, solar, expansiva força da natureza, como o pai, experimenta o sexo em meio à própria natureza. O nome sugestivo do lugar escolhido para tal prática, “Alto-Grande", leva a algumas possíveis interpretações. Afinal, pode-se pensar, não há

\footnotetext{
${ }^{40} \mathrm{O}$ "Alto Grande", sem hífen, é mencionado na primeira visita de Miguel ao Buriti Bom (B, 123), quando é conduzido por Gualberto até a propriedade, estando no extremo oposto à "Baixada", onde fica o Brejão do Umbigo.
} 
do que se envergonhar do feito em si, sendo possível ratificá-lo, se se quiser, de forma alta, grande, como quem faz uma afirmação - ou se afirma enquanto sujeito - em "alto e bom som". Mesmo que se trate de algo "baixo" do ponto de vista da moral conservadora, posto que é relativo ao "baixo corporal" e, portanto, refreável e reprovável sem a bênção matrimonial, o texto rosiano mostra o oposto.

Não há, de qualquer forma, espaço para tal ousadia na "Casa" patriarcal. Liodoro e Lala - lembrando que láila, em hebraico, significa noite - desfrutam do "noturno rumor" para seus encontros, protegidos da voragem da natureza.

Lalinha e Liodoro "se conhecem" já nos últimos instantes da narrativa, diante da iminente partida da jovem, encerrando um ciclo. Maria da Glória, no entanto, inicia sua prática sexual num misto de desejo e desesperança - por crer que Miguel não voltaria. Corre o risco, portanto, de ficar presa ao "hábito viscoso" do lugar, denunciado por Lalinha em outro trecho. A esperança na realização plena, afetiva e sexual, vai sucumbindo para Maria da Glória, tornando plausível seu aprisionamento na mítica repetição do lugar. Tudo indica que isto não ocorrerá, ante a chegada sempre anunciada - mas efetivamente nunca colocada no papel - de Miguel. Prevalece, como no dizer de Adélia Bezerra de Meneses (2010, 121), a expectativa de que, pela lógica romanesca, o encontro efetivamente ocorra.

O "malpreso barco" do Buriti Bom finalmente se desamarra. Entre promessas e realizações - e não é disto que é feito o Amor? - o mítico lugar, marcado por sua excentricidade, torna possível, literariamente, algumas experiências afeitas ao amor, expõe algumas velhas práticas, como a sexualidade sem freio do patriarca, enquanto propõe outras novas, tais como o fantasiar e realizar de certas demandas eróticas, principalmente por parte das mulheres.

Em "Buriti", ainda que em breves trechos, ressoando a promessa de felicidade afeita ao menino Miguilim ("sempre alegre, Miguilim"), mas também à "menina" Lalinha ("Meu dever é a alegria sem motivo") - verdadeiros operadores das mudanças na novela - corpo e espírito, se entendem.

\section{6 - Post Scriptum - "Mulheres têm a ideia sem sossego..." / "Mulher tira} ideia é do corpo..."

Nhô Gualberto Gaspar profere suas máximas, cheias de consequências, carregadas de sentidos, por ocasião de um passeio à cavalo de Lalinha e Maria da Glória. Estas deparam com a flora do cerrado. 
tinham passado por lá, com as lobeiras se oferecendo roxos. E a faveira cacheada festiva. E o pau-terra. [...] O pau-santo começado a florir: flores alvas, carnudas, cheirosas, mel-no-leite, com coroa amarela de estames. Mas, não cheirassem de perto, porque era cheiro aborrecido, e mexente, que se dava daquelas cinco pétalas ajasminadas. Cheiro que põe vômitos em mulher grávida. (B. 119)

Note-se que a natureza exuberantemente dada não inspira em Lalinha e Maria da Glória os senões de nhô Gual. Se este vê a necessidade de um freio por causa do cheiro "aborrecido" e "mexente", principalmente numa mulher grávida (que não é o caso de nenhuma delas), as mulheres não controlam o impulso e passam a colher as flores. A descrição das flores não é menos sugestiva: ressaltam-se os aspectos plásticos, táteis e odoríficos, num clima festivo no qual a natureza se oferece sem reservas.

A entrega das mulheres à colheita das flores se dá, também, sem sinais de reserva. Observe-se que a ressalva com relação ao cheiro das flores, que atiça o mais primitivo dos sentidos, se relaciona justamente com a sexualidade em seu aspecto primordial, que diz respeito à reprodução. Sem contar que "colher/arrancar flores" se aproxima do verbo "deflorar", ou desflorar, que, segundo o Houaiss, significa "retirar ou perder as flores", permitindo aqui uma leitura de conotação sexual.

Apesar do que poderia supor o bom senso sertanejo de nhô Gualberto, as moças se deliciam com as flores de cheiro enjoativo e passam a colhê-las. "Colhiam daquelas flores, as mal-abertas - que nem ovos cozidos, cortados pelo meio; as abertas todas: como ovo estrelado e gema" (B. 119/120)

Mais uma vez, as flores são descritas em sua exuberância de cor e forma, agora fazendo menção ao seu aspecto comestível dos ovos cozidos ou "estrelados".

Ante o inesperado, nhô Gualberto sentencia a "ideia sem sossego" como sendo atributo feminino. A afirmação deve ser entendida como carregada da visão de mundo da personagem que a profere. Para Gualberto, talvez, o que se esperaria das mulheres é que estas tivessem sossego, tranquilidade, atendo-se, quiçá, ao seu lugar socialmente determinado. Tem-se, no entanto, diante da atitude de Lalinha e Maria da Glória, o oposto, uma vez que estas acabam por fazer aquilo que ele considera impensável, a 
saber, passar a colher as flores de cheiro "mexente" e "aborrecido", que não dão "sossego".

O narrador, por seu turno, esquadrinhando nhô Gualberto, aprofunda a descrição e a análise de sua postura corporal e psicológica, pouco antes desta personagem proferir a segunda máxima, "mulher tira ideia é do corpo":

Nhô Gualberto ria em cima de seu mole cigarro. Daí, era um sorriso, com senvergonhice e vergonha. Moderava um desdém, pelas mulheres, por seus dengos e atrevimentos de criaturinhas protegidas, em respeito mesmo de sua qualidade frágil. Assim, de mistura, uma admiração com gulodice, que ele não podia esconder. $(\mathrm{B}, 120)$

Numa visada mais geral, percebe-se logo que nhô Gaspar é todo mistura, todo ambivalência $^{41}$. A começar pela descrição do riso que se equilibra sobre um "mole cigarro", donde sai o sorriso carregado de dubiedade, de malícia e pudor.

A ambivalência se torna mais complexa com a mistura do respeito com desdém dirigido às mulheres, naquilo que tem a ver com certos atributos, a saber, os dengos e atrevimentos próprios à "fragilidade" destas. A mistura é evidente, admiração somada à gulodice que nhô Gualberto, assim como ocorrera com as mulheres em relação às flores, não consegue conter, sentenciando finalmente: “- Mulher tira ideia é do corpo...”

Ora, se ele é todo mistura, o que ele profere pode guardar tanto uma dose de preconceito quanto uma dose de verdade. Afinal, o que seria essa "ideia sem sossego", tirada "do corpo" que seria próprio do feminino? Obviamente que tentar responder tal questão poderia levar tal pesquisa ao fracasso. A melhor forma de elaborar uma resposta possível é voltar para o texto, levando em conta o contexto no qual as sentenças de nhô Gualberto aparecem e sua relação com a novela como um todo.

Já se viu que a ambiência da cena, assim como a de várias outras, é plena de sentido erótico. A fala de nhô Gualberto parece querer marcar uma diferença entre homens e mulheres. Ele é um homem, quase que totalmente dedicado à lida no campo,

\footnotetext{
${ }^{41}$ A mistura aqui referida, na verdade, é facilmente identificável nas demais personagens da novela, sendo possível, numa retomada sumária, observar o misto de conservador que transgride (Liodoro), a donzela que não espera o príncipe encantado (Glória), a nora que mantém as aparências enquanto seduz o sogro (Lalinha), etc.
} 
regido pela ética do trabalho e da acumulação, sempre maquinando uma forma de lucrar mais e, ainda, invejando a sorte de iô Liodoro. Casado, estéril, sem filhos, sua mulher Dona-Dona - nome sem nome, que impessoaliza a esposa - não guarda semelhanças físicas com Lalinha e Maria da Glória, cuja beleza é celebrada ao longo de toda a narrativa. Justamente por isso, talvez, se possa compreender o misto de "admiração com gulodice" ante duas moças tão "apetitosas".

A princípio, a ideia do homem - diferente da ideia da mulher - talvez fosse sossegada, tranquila, sem agitos e oriunda do espírito. Metódica, resultado do cálculo, pura racionalização, marcar-se-ia, assim, a perfeita distinção entre homem e mulher analisando a origem e a natureza da ideia.

Mas o testemunho e as ações de Gualberto o traem. O riso deixa entrever a "vergonhosa senvergonhice", que pode ainda ser associado às suas "vergonhas", forma popular de se referir aos genitais (presente, aliás, na própria Carta de Pero Vaz de Caminha ao se referir aos índios nus). Ademais, a admiração pode nascer da percepção de um objeto externo ao sujeito que lhe causa grande prazer. A esta, soma-se a gulodice, desdobramento e exacerbação da fome, experiência primitiva e essencial a todo ser humano.

Chega-se, portanto, ao encurtamento da distância pretendida pelo veredito deste sertanejo a separar homens e mulheres. Isto porque não há nada mais "sem sossego" e "do corpo" que as próprias ideias sentenciadas por nhô Gualberto. E, daí, que se poderia pensar que a origem e a qualificação da ideia é mais sem sossego e corporal do que se imagina, independentemente do fato desta ideia ser "masculina" ou "feminina", bastando pensar na contribuição da psicanálise para confirmar tal sentença.

Basta lembrar a afirmação de Freud de que "o Eu é sobretudo corporal" e seus desdobramentos, conforme citado anteriormente neste capítulo. Seria impossível, seguindo o raciocínio de Freud, conceber uma ideia, palavra ou ação que, em última instância, não guarde relação com o corpo, sede originária de todas sensações e manifestações do sujeito.

Ainda a respeito da influência do corpo sobre o psiquismo, e vice versa, vale mencionar um pequeno trecho de "Dão-Lalalão", objeto de estudo da dissertação de 
mestrado (ROCHA, 2009), que revela esta mesma tendência na ficção de Rosa. O exemplo vale aqui como mais um sinal da indissociabilidade entre corpo e ideia que vem sendo defendida na presente argumentação:

Vinham através de um malhador de pasto, a poeira vaporosa do esterco bovino chamava do sangue de Soropita um latejo melhor, um tempero de aconchego. Com o calor que o coxim da sela lhe passava para o fundo-das-costas - um calor grosso, brando, derramável, que subia às virilhas e se espalhava e enrijava - $o$ bem do corpo tomava mais parte no pensado, o torneio das imagens se espessava. (D-L, 17/18, grifos meus) ${ }^{42}$

Não resta dúvida - escusado o desvio de rota - de que a tentativa de Gualberto de associar a ideia e o corpo ao universo feminino não procede. E isto, não apenas pelo que se expõe nas linhas de "Buriti", mas porque o próprio autor marca a continuidade entre as mais básicas sensações físicas, o "bem do corpo", e as imagens e pensamentos, o "pensado" e o "torneio das imagens". Evidencia-se o tom preconceituoso da afirmação e o caráter entre o irônico e o caricatural da composição de Gualberto nesta passagem.

Talvez seja justamente essa a função desse olhar de Gualberto para a economia narrativa: representar, no interior da novela, uma perspectiva mais retrógrada em relação aos valores dissonantes da mulher, trazidos à tona pelo escritor. Cria-se uma espécie de dupla percepção do feminino para que o leitor construa a sua visão.

A sequência do trecho analisado acima traz ainda mais elementos para que se reflita sobre as relações do corpo com o erotismo presentes no texto:

Nhô Gualberto Gaspar contava: - "Vai, não aguentei, eu quis mostrar uma coisa, elas haviam de abrir boca! Estimo que nem a Maria da Glória, que é de casa, não conhecia..." Ele descera do cavalo, pegou o machete, caçou um pau-terra. Torou o pé. [...] Mostrara que, naquela árvore viva, com copa folhada e porção de flores que eram estrelinhas amarelas alegres - que o tronco era oco, como uma flauta grossa, e todo cheio de terra, uma coluna de terra, de chão, terra crua, de verdade, subida em tanta altura. Essa terra seca, interna guardada, dentro mesmo do corpo todo da árvore verde. A bem que elas duas - Dona Lalinha e Maria da

\footnotetext{
${ }^{42}$ Utiliza-se aqui a mesma convenção para a citação dos textos de Guimarães Rosa: D-L, para "DãoLalalão" seguido do número de página.
} 
Glória - levaram um espanto, no aquilo avistar, como se fosse uma coisa imoral. (B, 120 - grifos meus)

A "estúrdia vingança" do sertanejo relaciona-se com a revelação de um fato desconhecido pelas moças, tencionando o fim do deleitoso colher de flores de Maria da Glória e Lalinha por meio da apresentação de uma verdade da natureza que até então passava despercebida, não fosse a matreirice de Gualberto.

O sertanejo, que não se aguenta, põe em prática aquilo que seria próprio das mulheres, num rompante "sem sossego", tira de si - de seu corpo - uma ideia para colocá-la em execução e assim afetar a sensibilidade alheia, no caso, feminina. Ao cortar o tronco do pau-terra Nhô Gualberto apresenta o outro lado do espetáculo da natureza, contrapondo a "copa folhada e porção de flores que eram estrelinhas amarelas alegres" com o tronco recheado de terra seca "dentro mesmo do corpo todo da árvore verde". Sua intervenção atinge o objetivo premeditado, causa espanto, fazendo as moças "abrir boca", como diante de algo obsceno, de uma imoralidade.

Para além da beleza das flores, oculto, há o tronco, o falo ereto e intumescido ainda que de elemento seco - que é condição inata à florescência do pau-terra. Salientese aqui o efeito provocado pelo "corpo todo da árvore" sobre o corpo de Lalinha e Maria da Glória, boquiabertas pela verdade da natureza, pela "surdina" que se insinua na "rotina" dos passeios pelo campo. 
Considerações Finais 


\section{Considerações finais}

Para concluir esta tese, cabe retomar, suscintamente, alguns pontos desenvolvidos nos capítulos precedentes.

Estudou-se, no primeiro capítulo, a erotização da natureza, dispersão do erotismo humano sobre os mínimos recantos da natureza que cerca a ambientação narrativa, a ponto da própria natureza atuar como uma personagem. Do Buriti Grande ao Brejão do Umbigo - ápices desta erotização - até os trechos mais imperceptíveis, aparentemente meras descrições, Rosa faz do sertão corpo vivo, pulsante, a enredar com suas formas, cores, cheiros, texturas as personagens humanas. Via de dupla mão, como se viu, derrama-se a subjetividade sobre os fenômenos naturais, mas, diferente da projeção que marca o puro animismo, o que é da ordem do humano impregna a natureza e atesta que ambos partilham de uma mesma língua universal.

No segundo capítulo, a partir de algumas indicações da narrativa, visando aprofundar o estudo do "corpo da noite", realizou-se uma investigação, semelhante à do primeiro capítulo, sobre a presença da mitologia indígena e sua relação com certos elementos da natureza presentes no texto, como a noite, a lua e o mutum, tendo como ponto de partida o mito da Cobra Grande. A insistência na análise destes elementos textuais relativos ao ambiente, ao espaço da ação, contribuiu para aprofundar as sugestões do próprio narrador quanto ao caráter extraordinário ("ali nada podia acontecer, a não ser a lenda") e excêntrico ("retirado de rota", "ponto remansoso") do Buriti Bom. Em certa medida, é justamente por estarem ali, inseridos neste espaço e sob a influência da valoração simbólica destes elementos, que as personagens têm a ocasião para também agirem de forma excepcional, ou mesmo transgressora.

No terceiro capítulo, em decorrência da força dos elementos da natureza presentes no texto, analisou-se o encontro dos representantes de dois clãs distintos, circunscritos à literatura rosiana, a saber, o filho do mutum - Miguel - e a filha do buriti - Maria da Glória - tendo em vista que estes trazem no nome a marca "por varonia" da força da terra. A pregnância das emanações eróticas do sertão tornam-se a própria carne das personagens, sendo os sobrenomes das famílias/clãs o signo deste fenômeno. Além disso, a introjeção/incorporação dos derivados totêmicos - a carne do mutum, o doce e o licor do buriti - nos moldes de um banquete, reforçam a ideia sustentada do pertencimento ao clã. Portanto, a categoria do totemismo, pensada de acordo com a antropologia estrutural de Lévi-Strauss, serviu como meio de reflexão para entender a 
dinâmica de cada um destes clãs em relação ao fenômeno amoroso e seus possíveis desdobramentos dentro da narrativa. Em "Buriti" encena-se a possibilidade de algo novo, de um casamento - suposto entre Miguel e Maria da Glória - que os levassem mais além do peso das respectivas heranças totêmicas, apontando para um percurso mais afeito à lógica do desejo - daí o contraponto com a figura de Lalinha.

Por fim, no quarto capítulo, feitas as considerações acerca do "corpo da noite", signo da natureza eroticamente investida, a análise se volta para as representações do corpo das personagens, tendo por base as contribuições psicanalíticas relativas ao conceito de pulsão e corpo erógeno. Parte do erotismo manifesto pelas personagens da novela relaciona-se com a inserção destas no sertão saturado de erotismo, do "corpo com corpo" entre a terra e o homem. A resposta corporal das personagens se articula no sentido de devolver os frutos nascidos deste contato entre o interno e o externo, nas reações das personagens registradas via narrador, ou nas fantasias, solilóquios, diálogos e atitudes destas personagens postas em ato ao longo da narrativa.

Feito este breve resgate do desenvolvimento da tese, para encaminhar as últimas reflexões deste trabalho, vale considerar os termos dos filósofos Adorno e Horkheimer (1985, p. 28.) abaixo:

A obra de arte ainda tem em comum com a magia o fato de estabelecer um domínio próprio, fechado em si mesmo e arrebatado ao contexto da vida profana. Neste domínio imperam leis particulares. Assim como a primeira coisa que o feiticeiro fazia em sua cerimônia era delimitar em face do mundo ambiente o lugar onde as forças sagradas deviam atuar, assim também, com cada obra de arte, seu círculo fechado se destaca do real.

No domínio próprio de sua arte, Guimarães Rosa cria - como já se disse aqui insistentemente - um lugar marcado com a signo da excepcionalidade, que se destaca do real, parafraseando os pensadores alemães. A fazenda do Buriti Bom, como um parêntese dentro de outro, espaço mítico circunscrito dentro de uma ficção, é delimitada pela singular eroticidade de sua natureza. A razão deste estudo é propor a compreensão deste fenômeno, respondendo à questão do porquê, afinal, tantos signos eróticos espalhados pelo texto/propriedade rosiano. Qual a função, a finalidade desta saturação erótica no texto, a começar pela natureza, passando pelas personagens, supondo que seja possível marcar um ponto onde os fenômenos começam deveras no sertão literário de Guimarães Rosa? Sendo esse sertão pleno de redemoinhos e brejos, entre outras 
imagens da mistura e da fusão, trabalha-se aqui tendo como fundo a impossibilidade de estabelecimento de um ponto de referência que signifique certeza.

A leitura que aqui se propõe de "Buriti" é desta novela figurar, justamente, uma "ponte", imagem evocada por Gunter Lorenz ${ }^{43}$. Entre o espaço/tempo mítico, edênico, e o sertão histórico, representado ficcionalmente por Rosa, observa-se um trânsito relativamente livre.

Tendo partido da natureza, evocado no mito hebraico da criação, o "corpo da noite" toca centralmente a questão amorosa. Dessa forma, e já fazendo uso desta "ponte" suposta por Lorenz, tem-se que as condições para a liberalidade ou a restrição à vida amorosa, sexual, e as diferenças destas possibilidades em relação a homens e mulheres, são fenômenos constituídos historicamente, embora possam se revestir de uma aparência quase mítica. O senhorio de Liodoro sobre suas "fêmeas exatas" - dentre elas a esposa de um agregado e uma negra trazida da Bahia para "uso" exclusivo do patriarca - é bem herdado do contexto da sociedade patriarcal e escravocrata brasileira. Da mesma forma, a salvaguarda da honra das filhas mulheres sob a tutela do pai, e a maior liberdade concedida aos filhos homens. Estes que, aparentemente, são "dados" constitutivos da sociedade brasileira, míticos no sentido daquilo que está arraigado à história a ponto de ser considerado "natural" vão, por força das transformações sociais, sendo postos em xeque.

Marcadas as diferenças entre o contexto de produção das reflexões de Roland Barthes sobre sua concepção de mito e a matéria por ele analisada, parece pertinente fazer uso de suas elaborações para pensar alguns aspectos da narrativa de Rosa quando esta toca, ainda que indiretamente, a perpetuação de uma forma de viver, uma ideologia com sua reprodução quase automática, "natural", inquestionável ao longo dos tempos. Nas práticas assinaladas no parágrafo acima, típicas da sociedade patriarcal brasileira, percebe-se a configuração disto que o semiólogo francês denomina mito contemporâneo: "o mito é uma fala despolitizada. [...] política no sentido profundo, como conjunto das relações humanas na sua estrutura real, social, no seu poder de construção do mundo." Ou, dito de outra forma: “o mito é constituído pela eliminação

\footnotetext{
${ }^{43}$ A passagem de Gunter Lorenz, citada no capítulo1 desta tese, pode ser colocada em outros termos, segundo o próprio Rosa na famosa entrevista entre ele, Rosa, e Lorenz. Rosa afirma: "No sertão, o homem é o $e u$ que ainda não encontrou um $t u$; por isso ali os anjos ou o diabo ainda manuseiam a língua. O sertanejo, você mesmo (Lorenz) escreveu isso, "perdeu a inocência no dia da criação e não conheceu ainda a força que produz o pecado original"." (LORENZ, 1973, p. 86)
} 
da qualidade histórica das coisas: nele, as coisas perdem a lembrança da sua produção." (BARTHES, 1980, p. 163)

O peso das tradições - embutido na concepção barthesiana de mito - versus a força, ou o desejo, de mudança numa sociedade tradicional que sente as influências das transformações trazidas pelo tempo, no tocante à ética amorosa, é o que se desenha em "Buriti". A possibilidade de realizar ou não esta mudança passa por atravessar este território que constitui o chão, "brejo", da realidade social brasileira a fim de vislumbrar, ao final da travessia, novas possibilidades.

Dessa forma, ainda que se possa afirmar relativa legitimação das práticas sexuais na perspectiva masculina - leia-se Liodoro - identifica-se simultaneamente certo questionamento em relação ao privilégio masculino, patriarcal, na medida em que deixa-se vir à tona uma igualdade possível, seja pelo relato de Do-Nhã - exemplo do que é permissível e ou possível no sertão ficcional de Rosa, misto de relato oral, “causo", e invenção poética - seja pela própria mimese do comportamento paterno feito por Glorinha. Isso tudo sem contar a presença de Lalinha, moça da cidade de inquestionável importância para a construção de outra perspectiva neste quadro.

Num espaço literário construído com múltiplas referências ao Éden bíblico, no qual o prosaísmo da história se mescla com o extraordinário ficcional, algumas categorias relativas a Eros são postas em perspectiva. Especificamente na segunda parte da narrativa, privilegiada pela proximidade da narrativa colada à personagem Lalinha, desenha-se este cenário de mito, de "lenda" e é dada a voz a uma categoria pouco ouvida e/ou lançada no papel - ao menos na ficção de Rosa até então - a saber, a voz feminina.

A perspectiva feminina, privilegiada neste entrecho, permite a expressão de liberdades de agir e pensar relativamente novas, mas sobretudo na consideração de uma igualdade possível no tocante às mulheres que, aqui, tomam a frente no falar e agir relativos à matéria amorosa. Alguns desejos e anseios ganham possibilidade de representação, chegando, em alguns trechos, a servir como verdadeiro laboratório de experiências daquilo que, eventualmente, poderia ser admitido com mais naturalidade no tecido social. Corrobora-se aqui o achado crítico de Cleusa Passos, ao afirmar a peculiaridade desta narrativa na qual "as mulheres têm voz" (2000, p. 58, grifo da autora), considerando o potencial transgressor e relativamente novo no horizonte narrativo do escritor mineiro, quiçá da produção literária brasileira. 
Delimita-se a questão: se em "Buriti” o amor é algo natural, que emana da terra, como mostraram, sobretudo os capítulos 1 e 2, e a Liodoro é permitido fruí-lo, miticamente, sem questionamentos, o mesmo não parece ocorrer em relação a estas mulheres como Lalinha e Maria da Glória. Apartadas da possibilidade "natural" do desfrute erótico, posto que mais suscetíveis às restrições da "Família" (em maiúscula no texto de Rosa), caberá a estas personagens lidar com estas separações, a começar por compreender a distinção fundante entre corpo e espírito: "o espírito que compreendesse o corpo", além de buscar uma forma de realizar, de por em prática tal compreensão.

A distinção da perspectiva de Lalinha e Maria da Glória em relação à de Liodoro é fundamental. Para o patriarca, sua prática erótica se assemelha, mimeticamente, à uma força da natureza, não havendo registro de culpabilidade ou algo semelhante, o que diz de uma prática "naturalizada" nos moldes do pensamento barthesiano, ou seja, um dado histórico, social, que devido à sua perpetuação por longas gerações parece não ser mais um hábito humano construído no tempo e no espaço, mas algo tão natural e evidente como a chuva ou o cio dos animais.

Trata-se de contrapor, portanto, Liodoro, "garanhão ganhante" que, miticamente, quase como o princípio fecundante de um Zeus sertanejo, tem acesso irrestrito a todas as fêmeas e estas fêmeas, as personagens Lalinha e Maria da Glória - que se afastam deste fundo mítico de recato e espera pelo "príncipe encantado" donas de si, sujeitos do desejo, lidando com as possibilidades e proibições de um erotismo encarnado historicamente. Os serões de Lalinha e Liodoro teriam, então, a função de interpor a esta força da natureza uma barreira, iniciando o patriarca na "força da cultura", fazendo-o encarar a contenção, a contemplação do belo, fazendo valer o aspecto simbólico da palavra, veículo privilegiado, mas não exclusivo, do gozo sexual. Só após a carta de Irvino, desmanchando a conotação de um possível incesto, faz-se a ocasião para a consumação do desejo.

Para Maria da Glória ${ }^{45}$, mulher, criada em colégio da cidade grande e inserida nesta família tradicional, lidar com as proibições inerentes ao seu meio é algo que se

\footnotetext{
${ }^{44}$ A evocação ao gênero do conto de fadas não é acidental, devendo ser entendido com toda sua força a levando em conta a implicação histórica e social relativa às expectativas que comumente recaem sobre as mulheres.

45 Diferente de Diadorim, a donzela guerreira, que tem de esconder sua condição feminina para lutar, como os homens, luta de morte, Maria da Glória "luta" pela possibilidade de se afirmar em sua
} 
põe em questão, pelo menos a partir de seu enamoramento por Miguel. A função de seus diálogos com Lalinha, quando divide com a cunhada seus anseios, dúvidas, fantasias, é justamente a de testar os limites que, aos poucos, ela experimenta romper.

Sob o fundo mítico da submissão feminina - pressuposto histórico tão naturalizado quanto a liberdade sem limites do patriarca Liodoro - Maria da Glória vai ao encontro de sua autonomia, ou da realização de sua demanda amorosa. Parte dessa índole amorosa é herdada na linhagem paterna, força da natureza. Outra, revela o impulso por tornar-se senhora de si, na medida em que reconhece o que se pode aproveitar escondido e vai ao encontro disto que há "de melhor", rompendo, à sua maneira, os interditos que mantinham-na na condição de espectadora, conquistando para si a realização erótica possível, no encontro com o compadre Gualberto.

Embora o caráter repressivo, sobretudo à condição feminina, não seja abertamente exposto e problematizado em "Buriti", parece evidente que isto vem subentendido nas diversas restrições mais ou menos explícitas já analisadas ao longo deste estudo. A singularidade do texto rosiano passa pelo fato de criar este ambiente mítico para, nele, encenar situações que criticam, justamente, alguns fundamentos do funcionamento da sociedade brasileira.

Em termos críticos, portanto, a conclusão da análise e interpretação aqui realizadas afina-se com o pensamento da filósofa brasileira Marilena Chauí (1984, p. 229.), quando, ao escrever sobre a repressão sexual no contexto da sociedade brasileira, expõe: "aparentemente pontual e localizada, a crítica da repressão sexual atinge as estruturas da sociedade brasileira no seu todo."

Por seu turno, a evocação do princípio, da origem - matéria mesma da narrativa que caracteriza o mito do Jardim do Éden, entre outros - contribui para por em suspensão o momento histórico representado na narrativa e encenar outras "estórias" que funcionam como lampejos, horizontes possíveis que podem, ou não, vir a se integrar à história.

À medida que a pesquisa avançou, a força do mito e sua relação com a fatura literária de "Buriti" foi se impondo, tanto pela direta menção bíblica como pela referência à cultura dos índios do Brasil ou mesmo ao usar $O$ banquete de Platão como

feminilidade. Suas armas são outras, suas formas são exuberantes e ela faz questão de deixá-las à mostra tanto quanto possível, no extremo oposto de Diadorim. 
meio de reflexão, lembrando o dizer de Andre Jolles sobre o valor mitológico da figura de Sócrates na obra platônica ${ }^{46}$. A força desta categoria pode ser pensada de forma dupla: tanto na construção de um "mito de origem", que justifica ou naturaliza aquilo que é da história, quanto a própria liberdade de pensar um caminho ainda não trilhado, mas imaginável, portanto possível, dada certa plasticidade do próprio mito.

Novamente, o raciocino desenvolvido aqui se afina com o pensamento de Marilena Chauí: “[...] o possível é o que jamais foi feito e, no entanto, poderia ser feito - é possibilidade e não probabilidade. É o que não possui a menor garantia prévia de que acontecerá." (1984, p. 230, grifos da autora) Seguindo este curso, pode-se afirmar que a função da literatura é justamente propor outras realidades que dialetizem com as condições dadas historicamente, dentre as quais, algumas, sob condições específicas, podem tocar o possível no plano da vida humana, seja no plano do pensamento seja no da realização.

Ora, retomando a pergunta feita acima, sobre a razão de todos os elementos eróticos espalhados pelo texto, constata-se que na construção desta ponte - "Buriti" entre mito e história, o corpo, como se viu, tem papel central.

A constituição do corpo da natureza semelhante ao corpo do homem, retomando o pensamento de Vico exposto no capítulo 1, teve papel fundamental na interpretação aqui proposta, uma vez que a referida excepcionalidade do lugar se faz às custas da montagem deste cenário, no qual nada é ao acaso, antes, pleno de uma eroticidade toda ela excepcional. A aproximação com a mitologia dos índios brasileiros só evidenciou a ligação entre terra - corpo - e homem - nascido da terra. Caberia refletir se Vico não expõe em termos filosóficos, mas em perspectiva inversa, o que os índios, nas suas narrativas míticas, já identificavam. Seguindo o princípio do pensamento de Vico, o erotismo vai do homem para a natureza, enquanto para os índios o homem seria resultado de um princípio erótico inerente à natureza.

Assim, em "Buriti" não haveria como fugir ou ser indiferente a este chamado forma possível de se entender os ruídos que formam o "corpo da noite”. A natureza é o extra-ordinário, o "retirado de rota", pois não importa se brejo, buriti, espíntria, lua,

\footnotetext{
${ }^{46}$ Lê-se em Andre Jolles (1976, p. 98): “[...]que é a figura de Sócrates, tal como criada na obra platônica, nos escritos de Platão, senão essa forma literária que procuramos? Que é Sócrates senão o próprio mito platônico, o oráculo que, interrogando o universo, obriga-o a tornar-se coerente, a denunciar seu verdadeiro ser?"
} 
mutum, noite, tudo está ali a evocar o sentido do erótico, não sendo possível esperar, a rigor, outra resposta do humano - ele também natureza - a não ser apresentar certo grau de concordância e conformidade com o local. Nada é tão simples, porém, pois o atrito se dá, já se viu, entre este fundo mítico e a história, que impõe condições, interditos, próprios ao amor humano.

Tal é a função da disseminação dos elementos eróticos da natureza no texto: criar a saturação que ao mesmo tempo constrói o caráter mítico do lugar e tocar - no “corpo com corpo" - as personagens, agenciando-as também para suas práticas eróticas. Graças a esta saturação, retirada de rota e lendária, este ambiente ao mesmo tempo longínquo (bem delimitado na sua distância ficcional) e acessível (ao leitor interessado), algumas barreiras referentes ao amor são suspensas, tornando possível, justamente, este intercâmbio entre mito e história, nos termos expostos acima.

O fato é que a insistência de Rosa nas "ninharias mortais" que constituem o corpo, humano ou não, ao longo de "Buriti", merecem destaque na constituição desta novela retirada de rota. Homólogo à natureza, o corpo das personagens humanas, é todo ele constituído de "territórios eróticos" 47 , que merecem atenção do narrador e das próprias personagens, pois não há como falar do amor sem que se leve em conta sua dimensão corpórea.

Por isso, a investigação em torno dos elementos que compõem a corporeidade erógena das personagens, no capítulo 4, contribui tanto para a compreensão de certos aspectos pouco analisados pela fortuna crítica de "Buriti" quanto para refletir sobre a fonte, origem e destino último da ficção, a saber, o próprio corpo. A compreensão do corpo pelo espírito, busca de uma personagem (Lalinha) que reverbera, quiçá, o anseio de muitos leitores, é apresentada aqui, numa de suas inúmeras formas possíveis.

E não por acaso a importância do corpo nesta obra, proposta desta tese, faz reverberar, no detalhe, a relação da novela que encerra o ciclo de narrativas com o todo maior, que intitula a publicação em sua forma original, o Corpo de baile.

Corpo, conjunto disperso, palco das paixões, em constante movimento, pois mesmo quando repousa ainda sonha, produz ficção. Corpo feito livro, nele se lê o impossível que quer transpor a barreira e ser corpo vivo, diminuir as distâncias para

\footnotetext{
${ }^{47}$ A expressão é de Joel Birman, conforme BIRMAN, 1999, p. 32. “[...] o corpo sexual foi fragmentado numa diversidade quase infinita de territórios eróticos, de maneira tal que o órgão genital seria apenas um dos recantos possíveis que permitiriam o gozo e o prazer." (grifo do autor)
} 
depois repô-las. "Buriti": neste fim começo, indicativo de uma nova leitura, fica a proposta para o leitor de olhar, o texto ou a vida, de corpo inteiro. 
REFERÊNCIAS 
I - Obras de Guimarães Rosa

Corpo de baile. Edição comemorativa 50 anos. Rio de Janeiro: Editora Nova Fronteira, 2006 (dois volumes).

Noites do sertão. $4^{\text {a }}$ ed. Rio de Janeiro: José Olympio, 1969.

No Urubuquaquá, no Pinhém. 4ª ed. Rio de Janeiro: José Olympio, 1969.

Manuelzão e Miguilim. 6ª ed. Rio de Janeiro: José Olympio, 1976.

Grande sertão: veredas. $2^{\text {a }}$ ed. Rio de Janeiro: José Olympio, 1958.

Primeiras estórias. $10^{\mathrm{a}}$ ed. Rio de janeiro: José Olympio, 1977.

Tutaméia. $5^{\text {a }}$ ed. Rio de Janeiro: José Olympio, 1979.

II - Bibliografia Geral.

ADORNO, T. Notas de literatura I. Trad. Jorge de Almeida. São Paulo: Duas Cidades: Editora 34, 2003.

ADORNO, T. \& HORKHEIMER, M. Dialética do esclarecimento. Trad. Guido Antonio de Almeida. Rio de Janeiro: Zahar, 1985.

ARAÚJO, H. V. A raiz da alma. São Paulo: EDUSP, 1992.

ARRIGUCCI JR., D. "Romance e experiência em Guimarães Rosa." Novos Estudos Cebrap. São Paulo, nº 40, Nov. 1994.

E. Introdução aos estudos literários. Trad. José Paulo Paes $2^{\mathrm{a}}$ ed.

São Paulo: Cultrix, 1972.

BACHELARD, G. A água e os sonhos. Trad. Antonio de Pádua Danesi. São Paulo: Martins Fontes, 1997.

BARTHES, R. Mitologias. $4^{\mathrm{a}}$ ed. Trad. Rita Buongermino e Pedro de Souza. São Paulo: Difel, 1980.

BATAILLE, G. “A linguagem das flores”, in Inimigo Rumor. Trad. Marcelo Jacques de Moraes e João Camillo Penna. São Paulo: Cosac Naify, nº 19, 2007.

BATAILlE, G. O erotismo. Trad. Fernando Scheibe. Belo Horizonte: Autêntica Editora, 2013.

Bíblia Sagrada. Distrito Federal: Sociedade Bíblica do Brasil, 1969.

BIRMAN, J. Cartografias do feminino. São Paulo: Editora 34, 1999. J. Mal-estar na atualidade. $6^{a}$ ed. Rio de Janeiro: Civilização Brasileira, 2007. 
BOPP, R. Cobra Norato e outros poemas. $12^{\mathrm{a}}$ ed. Rio de Janeiro: Civilização Brasileira, 1978.

BOSI, A. Céu, inferno - Ensaios de crítica literária e ideológica. São Paulo: Ática, 1988.

A. História concisa da literatura brasileira. $43^{\mathrm{a}}$ ed. São Paulo: Cultrix, 2006.

CAMPOS, H. Éden. São Paulo: Perspectiva, 2004.

CANDIDO, A. Tese e antítese. $2^{a}$ ed. São Paulo: Companhia Editora Nacional, 1971.

A. Vários escritos. $4^{\text {a }}$ ed. São Paulo/ Rio de janeiro: Duas Cidades/Ouro sobre Azul, 2004.

CALLIGARIS, E. R. Prostituição: o eterno feminino. São Paulo: Escuta, 2006.

CASCUDO, L.C. Dicionário do folclore brasileiro. $7^{\text {a }}$ ed. Belo Horizonte: Editora Itatiaia limitada, 1993. L.C. Geografia dos mitos brasileiros. Belo Horizonte: Editora Itatiaia, 1978.

L. C. Antologia do folclore brasileiro. São Paulo: Global, 2001.

CAVAlCANTI PROENÇA, M. Augusto dos Anjos e outros ensaios. Rio de Janeiro: José Olympio, 1959.

CHAUÍ, M. Repressão sexual - essa nossa (des)conhecida. $7^{\mathrm{a}}$ ed. São Paulo: Brasiliense, 1984.

COSTA, A. L. M. "Diadorim, delicado e terrível” Em Scripta. Revista do programa de Pós-Graduação em Letras e do CESPUC, Belo Horizonte, v. 5, n. 10, 1.Sem. de 2002.

COSTA LIMA, L. A metamorfose do silêncio. Rio de Janeiro: Eldorado, 1974.

Del PRIORE, M. Histórias íntimas - sexualidade e erotismo na história do Brasil. São Paulo, Editora Planeta do brasil, 2011.

DISCÓRIDES Plantas y remédios medicinales. Tradução: Manuela García Valdés, Madrid: Editorial Gredos, 1998.

ELIADE, M. O sagrado e o profano: a essência das religiões. Tradução: Rogério Fernandes. $3^{a}$ ed. São Paulo: Editora WMF/Martins Fontes, 2010.

FISHBURN. G. "Is that a Spintria in your pocket, or are you just pleased to see $\begin{array}{llll}\text { me?" in } & \text { Regarding the past: }\end{array}$ 
FREUD, S. "Sobre os sonhos" (1901) In Obras completas. Trad. Jayme Salomão. Rio de Janeiro: Imago, 1996.

S. "Três ensaios sobre a teoria da sexualidade" (1905) In

Obras completas. Trad. Jayme Salomão. Rio de Janeiro: Imago, 1996, vol. V.

S. "Totem e tabu” (1912) In Obras completas. Trad. Paulo César de Souza. São Paulo: Companhia das Letras, 2012, vol.VII.

S. "Os instintos e seus destinos" (1915) In Obras completas.

Trad. Paulo César de Souza: Companhia das Letras, 2010, vol XII.

S. "O eu e o id" (1923) In Obras completas. Trad. Paulo César de Souza. São Paulo: Companhia da Letras, 2011.

S. "O mal estar na cultura" (1930) In Obras completas. Trad.

Paulo César de Souza. São Paulo: Companhia da Letras, 2010.

GALVÃO, W. N. As formas do falso. $2^{a}$ ed. São Paulo: Perspectiva, 1986.

GARCIA-ROZA, L. A. Introdução à metapsicologia freudiana. $6^{\mathrm{a}}$ Ed. Rio de Janeiro: Jorge Zahar, 2004.

HOUAISS, A. Dicionário Houaiss da língua portuguesa. $1^{\text {a }}$ ed. Rio de Janeiro: Objetiva, 2001.

JOLLES, A. Formas Simples. São Paulo: Cultrix, 1976

KLEIN, M. et al. (org) Os progressos da psicanálise. $2^{\mathrm{a}}$ ed. Trad. Álvaro Cabral. Rio de Janeiro: Zahar, 1978.

LAPLANCHE, J. e PONTALIS J.-B. Vocabulário da psicanálise. Trad. Pedro Tamen. 2a ed. São Paulo, Martins Fontes, 1992.

LÉVI-STRAUSS, C. Minhas palavras. Trad. Carlos Nelson Coutinho, São Paulo: Brasiliense, 1986.

C. O pensamento selvagem. Trad. Tânia Pellegrini, $11^{\mathrm{a}}$ ed.

Campinas: Papirus, 2010.

, C. Totemismo hoje. Trad. Malcom Bruce Corrie. Petrópolis: Vozes, 1975.

LORENZ, G. "Diálogo com Guimarães Rosa" in, Diálogo com a América Latina. Trad. Rosemará Costhek Abílio. São Paulo, Ed. Pedagógica Universitária, 1973. 
LYNN, T., MARCHAND, A. Brazil: portrait of half a continent. New York: Dryden Press, 1951. (Serviço de biblioteca e documentação do Museu Republicano Convenção de Itu)

MACHADO, A. M. O recado do nome. São Paulo: Martins Fontes, 1991.

MARTINS, N. S. O léxico de Guimarães Rosa. 2 ed. São Paulo: EDUSP, 2001.

MENESES, A. B. ““'Dãolalalão” de Guimarães Rosa ou o "Cântico dos cânticos do sertão: um sino e seu badaladal.” Em Estudos Avançados, São Paulo, v. 22, nº 64 , set/dez 2008.

A.B. Cores de Rosa. São Paulo: Ateliê Editorial, 2010.

A. B. Do poder da palavra - Ensaios de literatura e psicanálise. $2^{\mathrm{a}}$ ed. São Paulo: Duas Cidades, 2004.

A. B. "Grande sertão: veredas e a psicanálise” Em Scripta. Revista do programa de Pós-Graduação em Letras e do CESPUC, Belo Horizonte, v. 5, n. 10, 1.Sem. de 2002.

MEYER, M. Ser-tão natureza - A natureza em Guimarães Rosa. Belo Horizonte: Editora UFMG, 2008.

MINDLIN, B. Vozes da origem. / [seleção e organização] Betty Mindlin e Narradores Suruí; tradução e transcrição das gravações: Antonio Ipokarã... [et al.]; narradores Suruí Dikboba... [et al.] Rio de Janeiro: Record, 2007

B. Moqueca de maridos: mitos eróticos. / Betty Mindlin e narradores indígenas $2^{\mathrm{a}}$ ed. Rio de Janeiro: Record: Rosa dos Tempos, 1998.

MORAES E. R. (org.) Antologia da poesia erótica brasileira. Cotia: Ateliê Editorial, 2015.

NOGUEIRA E. S. Vocalidade em Guimarães Rosa. Tese de Doutorado apresentada no Instituto de Estudos da Linguagem da Unicamp sob orientação da Profa. Dra. Adélia Bezerra de Meneses, 2014.

NOVAES, A. (org.) Ética. São Paulo: Companhia das Letras, 1992.

NUNES, B. O dorso do tigre. São Paulo: Perspectiva, 1969.

B. A clave do poético. São Paulo: Companhia das Letras, 2009.

OLIVEIRA, F. A dança das letras: antologia crítica. Rio de Janeiro: Topbooks, 1991. 
PACHECO, A. P. Lugar do mito: narrativa e processo social nas Primeiras estórias de Guimarães Rosa. São Paulo: Nanquim, 2006.

PASSOS, C. R. P. Guimarães Rosa: do feminino e suas estórias. São Paulo: Hucitec/Fapesp, 2000.

C. R. P. Confluências - Crítica literária e Psicanálise. São Paulo: Nova Alexandria/EDUSP. 1995.

C. R. P. "Os roteiros de Corpo de Baile: travessias do sertão e do devaneio". Em Scripta. Revista do programa de Pós-Graduação em Letras e do CESPUC, Belo Horizonte, v. 5, n. 10, 1.Sem. de 2002.

, C. R. P. "No giro da memória: literatura e psicanálise em GSV”. Em Cadernos de Literatura Brasileira, São Paulo, Instituto Moreira Salles, p, n. 20 e 21, p. 262-269.

PAZ, O. Corriente alterna. 19ª ed. Mexico: Siglo XXI Editores, 1990.

PLATÃO. Os pensadores. Trad.: José Cavalcante do Souza. $2^{\mathrm{a}}$ ed. São Paulo: Abril Cultural, 1983.

PLINY. Natural history. Tradução: W.H.S. Jones, $2^{\mathrm{a}}$ Ed. London: Harvard University Press, 1992.

PROUST, M. No caminho de Swann. Tradução: Maria Quintana, $3^{\circ}$ Ed. São Paulo: Globo, 2006.

RAMOS, R. (org.) Mídia, textos e contextos. Porto Alegre: EDIPUCRS, 2001.

ROCHA, E. S. Prazer de sombra: uma leitura de "Dão-Lalalão", de João Guimarães Rosa. Dissertação de mestrado apresentada no Departamento de Letras Clássicas e Vernáculas da USP, sob orientação da Profa. Dra. Yudith Rosenbaum, 2009.

RODRIGUES, J. B. Poranduba amazonense, ou kochiyma-uara porandub, 1890. Rio de Janeiro: Typ. de G. Leuzinger \& Filhos. [Permalink: http://biblio.etnolinguistica.org/rodrigues_1890_poranduba]

J. B. Exploração do rio Yamundá. 1875. 99pp. Acervo da Fundação Biblioteca Nacional - Brasil.

RONCARI, L. D. de A. Buriti do Brasil e da Grécia. São Paulo: Editora 34, 2013

RONCARI, L. D. de A. O Brasil de Rosa: mito e história no universo rosiano: o amor e o poder. São Paulo: UNESP, 2004 
L. D. de A. O cão do sertão - Literatura e engajamento. São

Paulo: Editora Unesp, 2007.

RONCARI, . de L. D A. "Patriarcalismo e dionisismo no santuário do Buriti Bom.” Em Revista do IEB, São Paulo, nº 46, fev 2008.

ROSA, J. G. Correspondência com seu tradutor italiano Edoardo Bizzarri. 3. ed. Rio de Janeiro: Nova Fronteira, 2003.

ROSA, J. G. Correspondência com seu tradutor alemão Curt MeyerClasson. Rio de Janeiro: Nova Fronteira, 2003.

ROSENFELD, A. Texto/contexto I. $5^{\text {a }}$ ed. São Paulo: Perspectiva, 1996.

SANGIRARDI JR. Plantas eróticas. 2a ed. Rio de Janeiro: Nórdica, 1981.

SUETONIO Tiberio Calígula. Tradução de Oliveri Nortes Valls, Barcelona: Bosch Casa Editorial S.A., 1983.

VICO, G. Os pensadores. Trad. Antonio Lázaro de Almeida Prado. São Paulo: Abril Cultural, 1974.

VIVEIROS de CASTRO, E. Metafísicas canibais. São Paulo: Cosac Naify, 2015.

WILBERT, J., SIMONEAU, K. Folk literature of the Yanomami Indians (editors), University of California, Los Angeles, 1990. 